Electronic Supporting Information

\title{
Amino Acid-containing Phase-selective Organogelators: A Water-based Delivery System for Oil Spill Treatment
}

Jun Chen ${ }^{\dagger}$, Charlotte E. Boott ${ }^{\ddagger}$, Lev Lewis ${ }^{\ddagger}$, Andrew Siu ${ }^{\dagger}$, Renad Al-Debasi ${ }^{\dagger}$, Veronica Carta ${ }^{\ddagger}$, Amanda A. Fogh ${ }^{\dagger}$, Daniel Z. Kurek ${ }^{\dagger}$, Lilo Wang ${ }^{\dagger}$, Mark J. MacLachlan*‡ and Gabriel Hum*十

†BC Research Inc., 12920 Mitchell Rd, Richmond, BC V6V 1M8, Canada

¥Department of Chemistry, University of British Columbia, 2036 Main Mall, Vancouver, British Columbia V6T 1Z1, Canada 


\section{General Experimental}

All reagents were commercially available and used as received unless otherwise noted. ${ }^{1} \mathrm{H}$ and ${ }^{13} \mathrm{C}$ NMR spectra were recorded on a Bruker Avance 400inv spectrometer. Infrared (IR) spectra were obtained using a PerkinElmer Frontier FT-IR spectrometer. Elemental analysis (EA) was performed on a Fisons Instruments Elemental Analyzer EA 1108 using flash combustion. Electrospray ionization (ESI) mass spectra were obtained on a Micromass LCT time-of-flight (TOF) mass spectrometer equipped with an electrospray ion source. Melting points were collected on a MelTemp machine. Differential scanning calorimetry (DSC) data were collected on a TA DSC250 under a $\mathrm{N}_{2}$ atmosphere. Rheological studies of gels were performed using a Discover HR-2 hybrid rheometer (TA Instruments, U.S.A.) equipped with a parallel plate geometry ( $8 \mathrm{~mm}$ diameter). Scanning electron microscopy (SEM) images were acquired on a Hitachi S4700 electron microscope. Confocal laser scanning microscopy images were obtained on a Zeiss LSM 800 microscope.

\section{High-resolution mass spectrometry}

Samples were dissolved in $\mathrm{MeOH}$ and heated with a heat gun (to $\sim 70{ }^{\circ} \mathrm{C}$ ) until fully dissolved. The working solutions were $\sim 1 \mathrm{mg} / \mathrm{mL}$. Flow rate: $20 \mu \mathrm{L} / \mathrm{min}$; sample cone: $90 \mathrm{~V}$; source temperature: $120{ }^{\circ} \mathrm{C}$; desolvation temperature: $120{ }^{\circ} \mathrm{C}$. For accurate mass measurements a reference compound was used and the mass locked; see the Table $\$ 2$ for more details.

\section{Differential scanning calorimetry}

Gel samples were heated from $40{ }^{\circ} \mathrm{C}$ to $145^{\circ} \mathrm{C}$ at a heating rate of $5^{\circ} \mathrm{C} \mathrm{min}-1$. A cooling run was taken after waiting $30 \mathrm{~s}$ at $145^{\circ} \mathrm{C}$ and then cooling at a rate of $5{ }^{\circ} \mathrm{C} \mathrm{min}-1$ to $40{ }^{\circ} \mathrm{C}$. The temperature cycle was repeated 4 times. The $\mathrm{T}_{\text {gel-sol }}$ and $\mathrm{T}_{\text {sol-gel }}$ of a gel were obtained as the average values from the last 3 cycles.

\section{Rheology}

For 1a decane gel $(5 \% \mathrm{w} / \mathrm{v})$, samples were prepared by dissolving the desired amount of gelator in decane by heating. The resulting hot solution was cooled to room temperature. After $30 \mathrm{~min}$, the gels were transferred to the plates by a spatula and were equilibrated at 25 ${ }^{\circ} \mathrm{C}$ between the plates at a gap of $1.0 \mathrm{~mm}$. For the $\mathbf{1} \mathbf{b}$ decane gel $(2.5 \% \mathrm{w} / \mathrm{v})$, samples were prepared by dissolving the desired amount of gelator in decane by heating. The resulting hot solution was poured into a $10 \mathrm{~mm}$ diameter Petri dish and cooled to room temperature. After $30 \mathrm{~min}$, the gels were trimmed and transferred to the plates and equilibrated at $25^{\circ} \mathrm{C}$ between the plates at a fixed axial force of 0.5 $\mathrm{N}$ with sensitivity of $0.1 \mathrm{~N}$. Amplitude sweeps were performed from 0.05 to $100 \%$ strain at a frequency of $1 \mathrm{~Hz}$. Frequency sweeps were performed from 0.1 to $100 \mathrm{~Hz}$ at a strain of $0.1 \%$. All the rheological measurements were done in triplicate.

For toothpaste, peanut butter, and $\mathbf{1 b}$ decane gel using water-based delivery system, amplitude sweeps were performed from 0.1 to $100 \%$ strain at a frequency of $1 \mathrm{~Hz}$ between the plates at a gap of $1.0 \mathrm{~mm}$ at $25^{\circ} \mathrm{C}$.

\section{Scanning electron microscopy}

Samples were prepared by placing a small amount of the gelled sample on an aluminum stub and allowing the solvent to evaporate. The samples were then sputter-coated with an $8 \mathrm{~nm}$ thick coating of a platinum/palladium (80:20) alloy prior to imaging.

\section{Confocal laser scanning microscopy}

For the heating-cooling method, the decane gel samples were prepared by casting a small amount of the hot gelator decane solution (8.8 $\mu \mathrm{M}$ Nile Red, $2.5 \% \mathrm{w} / \mathrm{v}$ ) on a warm Attofluor ${ }^{\mathrm{TM}}$ cell chamber and allowing the sample to cool to room temperature. The sample was observed with a confocal microscope using $1 \%$ of maximal power of a $561 \mathrm{~nm}$ laser, and a $63 x$ oil-immersion objective.

For the water-based delivery method, the aqueous network samples were prepared by casting a small amount hot gelator water solution $(17.6 \mu \mathrm{M}$ Crystal Violet, $5 \mathrm{mg} / \mathrm{mL})$ on a warm Attofluor ${ }^{\mathrm{TM}}$ cell chamber and allowing the sample to cool to room temperature. The sample was observed with a confocal microscope using $8 \%$ of maximal power of a $561 \mathrm{~nm}$ laser, and a $63 x$ oil-immersion objective.

For the water-based delivery method, the decane gels via aqueous network samples were prepared from phase selective gelation of decane $(8.8 \mu \mathrm{M}$ Nile Red, $2.5 \% \mathrm{w} / \mathrm{v})$. The sample was observed with a confocal microscope using $1 \%$ of maximal power of a $561 \mathrm{~nm}$ laser, and a $63 \times$ oil-immersion objective.

\section{Single-crystal X-ray diffraction (SCXRD)}

Single crystals were recrystallized from a mixture of water/isopropanol, 1:4 for 1a and 1:9 for $\mathbf{1 b}$. SCXRD raw data were collected on a Bruker APEX X8 diffractometer at $100 \mathrm{~K}$ for $\mathbf{1 a}$ and on a Bruker APEX DUO diffractometer at $90 \mathrm{~K}$ for $\mathbf{1 b}$. Graphite monochromated MoKa radiation $(\lambda=0.71073)$ was used and data were collected to a resolution of $0.77 \AA$. For more details see supplementary information and Tables S3-S12. 


\section{Determining the minimum gel concentrations}

The minimum gelation concentration (MGC in \% w/v) in oil was determined by the inversion test. ${ }^{1-6}$ In a typical test, the corresponding gelator (e.g. $25 \mathrm{mg}$ of $\mathrm{C} 12$-L-ala-CONH${ }_{2}$ ) was added into $1 \mathrm{~mL}$ of organic solvent (e.g. decane) in a $20 \mathrm{~mL}$ sample vial, which was then heated by heat gun until all the gelator was dissolved. The hot solution was cooled to room temperature under ambient conditions (approx. 10 $\mathrm{min}$ ). The sample was regarded as a gel if no flow was observed after inverting the sample vial. If a gel formed, an increment of $1 \mathrm{~mL}$ of solvent was added into the sample vial and the heating-cooling cycle repeated until flow was observed when the sample vial was inverted upon cooling. In some instances, sealed pressurized vials were used for determining the MGC of low boiling solvents. For $\mathrm{C}_{12}$-ala-CONH 2 $\mathbf{1 b}$ in decane, $25 \mathrm{mg}$ of C12-ala-CONH${ }_{2} \mathbf{1 b}$ can gel $14 \mathrm{~mL}$ of decane, giving rise to an MGC value of $0.18 \% \mathrm{w} / \mathrm{v}(25 \mathrm{mg} / 14 \mathrm{~mL})$.

Bhattacharya ${ }^{1}$ employed a different approach where the solvent was added in excess of the MGC. Following a heating and cooling step, a viscoelastic mass was formed and allowed to settle. The supernatant was decanted and weighed. The difference between the mass of solvent added and the mass of decanted solvent was considered the gelled fraction and used to calculate the MGC.
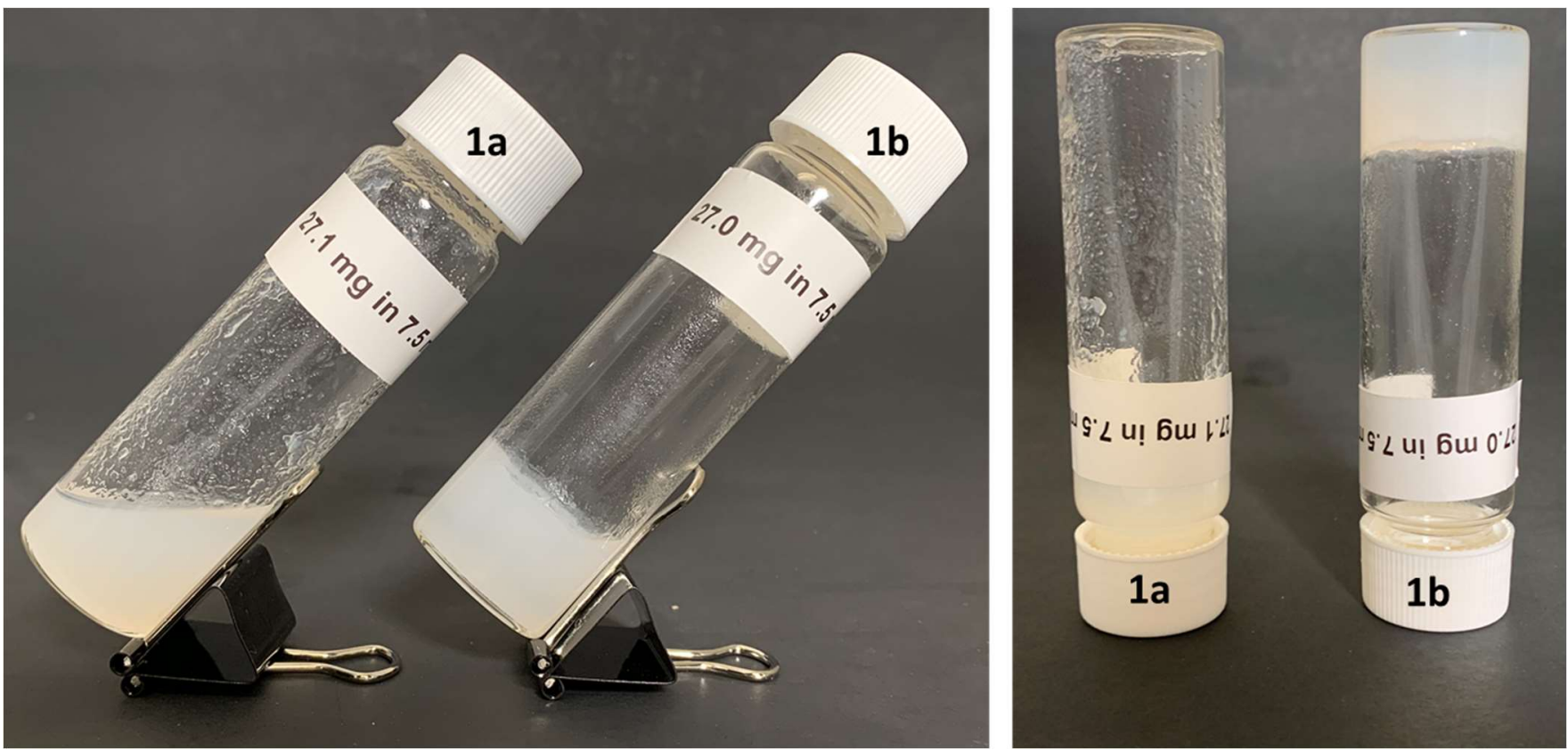

Figure S1. Evaluation of MGC using method by Bhattacharya7 with of 1a (left) and $\mathbf{1 b}$ (right) in $7.5 \mathrm{~mL}$ decane $1 \mathrm{mmol}$ (equivalent to $3.6 \%$ $\mathrm{w} / \mathrm{v}$ ) - MGC determined by weighing the decanted free solvent - gel of $1 \mathrm{a}$ is not stable to inversion.

Table S1. Thermal properties of decane gels of $\mathbf{1 a}$ and $\mathbf{1 b}$.

\begin{tabular}{|l|l|l|l|}
\hline Compound & Dosing $(\% \mathrm{w} / \mathrm{v})$ & $T_{\text {gel-sol }}\left({ }^{\circ} \mathrm{C}\right)$ & $T_{\text {sol-gel }}\left({ }^{\circ} \mathrm{C}\right)$ \\
\hline $1 \mathrm{a}$ & 5 & $75.1 \pm 3.7$ & $48.9 \pm 2.4$ \\
\hline $1 \mathrm{~b}$ & 5 & $115.8 \pm 0.1$ & $84.2 \pm 0.3$ \\
\hline
\end{tabular}

+ - stdev from $n=3$

\section{Phase-selective gelation of water-based delivery system}

The desired amount of gelator $\mathbf{1 b}$ was heated and dissolved in $5 \mathrm{~mL}$ of DI water. Upon cooling to room temperature, a network formed and occupied the whole volume of the vial. To the resulting network, $1 \mathrm{~mL}$ of oil was added via a pipette. The phase-selective gelation of the oil occurred within a minute with gentle swirling by hand.

\section{Oil Recovery Methods}

1. Syringe Filter

$20 \mathrm{mg}$ of $\mathbf{1 b}$ and $8 \mathrm{~mL}$ of DI water were heated at $100{ }^{\circ} \mathrm{C}$ for $30 \mathrm{~min}$ in an $20 \mathrm{~mL}$ vial, and was cooled to room temperature to allow network formation. $2 \mathrm{~mL}$ of oil blue dyed decane was then added to the network and the sample was left for 10 min to ensure complete decane uptake. The decane gel of $\mathbf{1} \mathbf{b}$ was then poured onto a nylon screen filter to remove free oil and DI water. The gel was then transferred to a $3 \mathrm{~mL}$ syringe with a $1.6 \mu \mathrm{m}$ syringe filter. Recovered decane $=1.58 \mathrm{~mL}, 79 \%$ 


\section{Distillation}

$80 \mathrm{mg}$ of $\mathbf{1 b}$ and $32 \mathrm{~mL}$ of DI water were heated at $100^{\circ} \mathrm{C}$ for $45 \mathrm{~min}$ in an $20 \mathrm{~mL}$ vial, and was cooled to room temperature to allow network formation. $4 \mathrm{~mL}$ of decane was then added to the network and the sample was left for $10 \mathrm{~min}$ to ensure complete decane uptake. The decane gel of $\mathbf{1 b}$ was then poured onto a nylon screen filter to remove free oil and DI water. The gel was then transferred to a $10 \mathrm{~mL} R B F$ and the decane was removed using vacuum distillation. Recovered decane $=1.92 \mathrm{~mL}, 48 \%$.

\section{Synthesis}

Procedure for the synthesis of C12-L-ala-COOH (1a): L-alanine methyl ester hydrochloride (5.00 g, 35.8 mmol, 1.0 eq.) was dissolved in chloroform $(90 \mathrm{~mL})$. Triethylamine $\left(7.97 \mathrm{~g}, 78.8 \mathrm{mmol}, 2.2 \mathrm{eq}\right.$.) was added to the solution at $0{ }^{\circ} \mathrm{C}$. Lauroyl chloride $(8.62 \mathrm{~g}, 39.4 \mathrm{mmol}, 1.1$ eq.) was then added dropwise to the solution and stirred overnight. The reaction mixture was diluted with chloroform and washed with 1 $\mathrm{M} \mathrm{HCl}(200 \mathrm{~mL}), 10$ wt. \% $\mathrm{NaHCO}_{3}$ aqueous solution $(500 \mathrm{~mL})$, and saturated brine and dried over anhydrous $\mathrm{Na}_{2} \mathrm{SO}_{4}$. The dried organic phase was concentrated under reduced pressure. The resulting crude intermediate was dissolved in methanol ( $100 \mathrm{~mL}$ ). Sodium hydroxide $(1.76 \mathrm{~g}, 43.9 \mathrm{mmol}, 1.2 \mathrm{eq}$.) was dissolved in water $(50 \mathrm{~mL})$ and added to the solution, then the mixture was stirred overnight. The solvent was removed by rotary evaporation and the aqueous residue was acidified with concentrated $\mathrm{HCl}$ to a $\mathrm{pH} 1$ and the resulting mixture was extracted with diethyl ether $(3 \times 100 \mathrm{~mL})$. The organic extract was washed with saturated brine and dried over anhydrous $\mathrm{Na}_{2} \mathrm{SO}_{4}$. The solvent was removed by rotary evaporation. The desired product was obtained as white solid $(7.41 \mathrm{~g}, 27.2 \mathrm{mmol}, 76 \% \mathrm{yield})$ and recrystallized in methanol/water $(9: 1) .{ }^{1} \mathrm{H} \mathrm{NMR}\left(400 \mathrm{MHz}, \mathrm{CDCl}_{3}\right): \delta 6.14(\mathrm{~d}, J=6.9 \mathrm{~Hz}, 1 \mathrm{H}), 4.58(\mathrm{dq}, J=7.0,7.1 \mathrm{~Hz}, 1 \mathrm{H}), 2.24(\mathrm{t}, J=7.3 \mathrm{~Hz}$, $2 \mathrm{H}), 1.65-1.50(\mathrm{~m}, 2 \mathrm{H}), 1.46(\mathrm{~d}, J=7.2 \mathrm{~Hz}, 3 \mathrm{H}), 1.33-1.23(\mathrm{~m}, 16 \mathrm{H}), 0.88(\mathrm{t}, J=6.3 \mathrm{~Hz}, 3 \mathrm{H}) .{ }^{13} \mathrm{C} \mathrm{NMR}\left(100 \mathrm{MHz}, \mathrm{CDCl}_{3}\right): \delta 176.0,174.3,48.4$, $36.6,32.1,29.7,29.6,29.5,29.4,29.3,25.7,22.8,18.2,14.3$. EA calcd for $\mathrm{C}_{15} \mathrm{H}_{29} \mathrm{NO}_{3}$ : N 5.16, C 66.38, $\mathrm{H}$ 10.77, found N 4.92, C 65.82, $\mathrm{H}$ 10.92. $\mathrm{HRMS}(\mathrm{ES})$ calcd for $\mathrm{C}_{15} \mathrm{H}_{29} \mathrm{NO}_{3}(\mathrm{M}+\mathrm{H})^{+} 272.2226$, found $272.2224 . \mathrm{mp}=80.3-81.6^{\circ} \mathrm{C}$.

Procedure for the synthesis of C12-L-ala-CONH $\mathbf{2}(\mathbf{1 b})$ : L-alaninamide hydrochloride (2.00 g, $16.1 \mathrm{mmol}, 1.0$ eq.) was dissolved in chloroform $(90 \mathrm{~mL})$. Triethylamine $\left(3.57 \mathrm{~g}, 35.3 \mathrm{mmol}, 2.2 \mathrm{eq}\right.$.) was added to the solution at $0^{\circ} \mathrm{C}$. Lauroyl chloride $(3.86 \mathrm{~g}, 17.6 \mathrm{mmol}, 1.1 \mathrm{eq}$.) was then added dropwise to the solution and the solution was stirred overnight. The reaction mixture was diluted with chloroform (100 $\mathrm{mL}$ ) and washed with $1 \mathrm{M} \mathrm{HCl}(3 \times 70 \mathrm{~mL}), 10 \% \mathrm{NaHCO}_{3}$ aqueous solution $(3 \times 80 \mathrm{~mL})$, and saturated brine $(3 \times 70 \mathrm{~mL})$ and dried over anhydrous $\mathrm{Na}_{2} \mathrm{SO}_{4}$. The desired product was suction filtered and obtained as white solid $(3.22 \mathrm{~g}, 11.9 \mathrm{mmol}, 74 \%$ yield) and purified by recrystallization in methanol/water (9:1). ${ }^{1} \mathrm{H}$ NMR $\left(400 \mathrm{MHz}, \mathrm{CDCl}_{3}\right): \delta 6.43(\mathrm{br}, 1 \mathrm{H}), 6.23(\mathrm{~d}, J=6.0 \mathrm{~Hz} 1 \mathrm{H}), 5.61(\mathrm{br}, 1 \mathrm{H}), 4.56(\mathrm{dq}, J=7.0,7.1 \mathrm{~Hz}, 1 \mathrm{H}), 2.19$ $(\mathrm{t}, J=7.5 \mathrm{~Hz}, 2 \mathrm{H}), 1.68-1.57(\mathrm{~m}, 2 \mathrm{H}), 1.39(\mathrm{~d}, J=7.0,3 \mathrm{H}), 1.36-1.20(\mathrm{~m}, 16 \mathrm{H}), 0.88(\mathrm{t}, J=6.3 \mathrm{~Hz}, 3 \mathrm{H}) .{ }^{13} \mathrm{C} \mathrm{NMR}(100 \mathrm{MHz}, \mathrm{CDCl}): \delta 175.3$, $173.8,48.8,37.1,32.4,30.1,29.9,29.8,29.8,29.7$ (2C), 26.1, 23.1, 18.5, 14.5. EA calcd for $\mathrm{C}_{15} \mathrm{H}_{30} \mathrm{~N}_{2} \mathrm{O}_{2}$ : N 10.36, C 66.62, H 11.18, found N 10.37, C 66.63, $\mathrm{H}$ 10.99. $\mathrm{HRMS}(\mathrm{ES})$ calcd for $\mathrm{C}_{15} \mathrm{H}_{30} \mathrm{~N}_{2} \mathrm{O}_{2}(\mathrm{M}+\mathrm{H})^{+} 271.2386$, found 271.2389. $\mathrm{mp}=132.7-134.7^{\circ} \mathrm{C}$.

Procedure for the synthesis of C12-D-ala-CONH $\mathbf{2}$ (1c): D-alanine methyl ester hydrochloride (2.00 g, $14.3 \mathrm{mmol}, 1.0$ eq.) was dissolved in chloroform $(50 \mathrm{~mL})$. Triethylamine $\left(3.19 \mathrm{~g}, 31.5 \mathrm{mmol}, 2.2 \mathrm{eq}\right.$.) was added to the solution at $0^{\circ} \mathrm{C}$. Lauroyl chloride $(3.45 \mathrm{~g}, 15.8 \mathrm{mmol}, 1.1$ eq.) was then added dropwise to the solution and the solution was stirred overnight. The reaction mixture was diluted with chloroform $(100 \mathrm{~mL})$ and washed with $1 \mathrm{M} \mathrm{HCl}(3 \times 70 \mathrm{~mL}), 10 \mathrm{wt} . \% \mathrm{NaHCO}_{3}$ aqueous solution $(3 \times 80 \mathrm{~mL})$, saturated brine $(3 \times 70 \mathrm{~mL})$, and dried over anhydrous $\mathrm{Na}_{2} \mathrm{SO}_{4}$, The solvent was removed in vacuo. The resulting crude intermediate $(1.50 \mathrm{~g}, 5.26 \mathrm{mmol}, 1.0$ eq. $)$ was dissolved in a 7 $\mathrm{M}$ ammonia in methanol solution, $(28.8 \mathrm{~mL}, 200.0 \mathrm{mmol}, 38.4$ eq.) and stirred overnight at room temp. The desired product was suction filtered and obtained as white solid $\left(1.32 \mathrm{~g}, 4.9 \mathrm{mmol}, 34 \%\right.$ yield) and recrystallized in methanol/water $(9: 1) .{ }^{1} \mathrm{H} \mathrm{NMR}(400 \mathrm{MHz}, \mathrm{DMSO}-$ $\left.\mathrm{d}_{6}\right): \delta 7.82(\mathrm{~d}, J=7.6 \mathrm{~Hz}, 1 \mathrm{H}), 7.25(\mathrm{br}, 1 \mathrm{H}), 6.91(\mathrm{br}, 1 \mathrm{H}), 4.19(\mathrm{dq}, J=14.6,7.3 \mathrm{~Hz}, 1 \mathrm{H}), 2.09(\mathrm{t}, J=7.4 \mathrm{~Hz}, 2 \mathrm{H}), 1.50-1.41(\mathrm{~m}, 2 \mathrm{H}), 1.32-1.19$ $(\mathrm{m}, 16 \mathrm{H}), 1.16(\mathrm{~d}, J=7.1 \mathrm{~Hz}, 3 \mathrm{H}), 0.85(\mathrm{t}, J=6.7 \mathrm{~Hz}, 3 \mathrm{H}) .{ }^{13} \mathrm{C}$ NMR $\left(100 \mathrm{MHz}, \mathrm{DMSO}-\mathrm{d}_{6}\right): \delta 174.3,171.6,47.5,34.9,31.1,28.8(2 \mathrm{C}), 28.7$, 28.6, 28.5 (2C), 25.0, 21.9, 18.1, 13.7. EA calcd for $\mathrm{C}_{15} \mathrm{H}_{30} \mathrm{~N}_{2} \mathrm{O}_{2}$ : N 10.36, C 66.62, H 11.18, found N 10.31, C 66.92, H 11.12. HRMS(ES) calcd for $\mathrm{C}_{15} \mathrm{H}_{30} \mathrm{~N}_{2} \mathrm{O}_{2}(\mathrm{M}+\mathrm{H})^{+} 271.2386$, found 271.2388. $\mathrm{mp}=135.8-137.4^{\circ} \mathrm{C}$.

Procedure for the synthesis of C12-DL-ala-CONH $\mathbf{2}$ (1d): DL-alanine ethyl ester hydrochloride (2.00 g, 13.0 mmol, 1.0 eq.) was dissolved in chloroform $(50 \mathrm{~mL})$. Triethylamine $\left(2.90 \mathrm{~g}, 28.6 \mathrm{mmol}, 2.2 \mathrm{eq}\right.$.) was added to the solution at $0{ }^{\circ} \mathrm{C}$. Lauroyl chloride $(3.13 \mathrm{~g}, 14.3 \mathrm{mmol}, 1.1$ eq.) was then added dropwise to the solution and the mixture was stirred overnight at room temperature. The reaction mixture was diluted with chloroform $(100 \mathrm{~mL})$ and washed with $1 \mathrm{M} \mathrm{HCl}(3 \times 70 \mathrm{~mL}), 10 \mathrm{wt} . \% \mathrm{NaHCO}_{3}$ aqueous solution $(3 \times 80 \mathrm{~mL})$, saturated brine $(3 \times 70 \mathrm{~mL})$ dried over anhydrous $\mathrm{Na}_{2} \mathrm{SO}_{4}$ and dried in vacuo. The resulting crude intermediate $(2.00 \mathrm{~g}, 6.68 \mathrm{mmol}, 1.0$ eq. $)$ was dissolved in anhydrous ethanol (30 mL). Ammonium hydroxide solution, $28 \% \mathrm{NH}_{3}$ in water $(35.7 \mathrm{~mL}, 260.0 \mathrm{mmol}, 38.4$ eq.) was added dropwise and the mixture was stirred overnight. The desired product was suction filtered and obtained as white solid (1.13g, $4.16 \mathrm{mmol}, 32 \%$ yield) and recrystallized in methanol/water (9:1). ${ }^{1} \mathrm{H}$ NMR $(400 \mathrm{MHz}$, DMSO-d 6 ): $\delta 7.83(\mathrm{~d}, J=7.7 \mathrm{~Hz}, 1 \mathrm{H}), 7.25(\mathrm{br}, 1 \mathrm{H}), 6.92(\mathrm{br}, 1 \mathrm{H}), 4.20(\mathrm{dq}, J=14.8,7.1 \mathrm{~Hz}, 1 \mathrm{H})$, $2.09(\mathrm{t}, J=7.4 \mathrm{~Hz}, 2 \mathrm{H}), 1.52-1.39(\mathrm{~m}, 2 \mathrm{H}), 1.34-1.19(\mathrm{~m}, 16 \mathrm{H}), 1.17(\mathrm{~d}, J=7.1,3 \mathrm{H}), 0.86(\mathrm{t}, J=6.9 \mathrm{~Hz}, 3 \mathrm{H}) .{ }^{13} \mathrm{C} \mathrm{NMR}\left(100 \mathrm{MHz}, \mathrm{DMSO}-\mathrm{d}_{6}\right): \delta$ 174.6, 172.0, 47.0, 35.3, 31.5, 29.2, 29.2, 29.2, 29.0, 28.9 (2C), 25.4, 22.3, 18.6, 14.2. EA calcd for $\mathrm{C}_{15} \mathrm{H}_{30} \mathrm{~N}_{2} \mathrm{O}_{2}$ : N 10.36, C 66.62, H 11.18, found $\mathrm{N} 10.12, \mathrm{C} 66.45, \mathrm{H}$ 11.55. HRMS(ES) calcd for $\mathrm{C}_{15} \mathrm{H}_{30} \mathrm{~N}_{2} \mathrm{O}_{2}(\mathrm{M}+\mathrm{Na})^{+}$293.2205, found 293.2207. $\mathrm{mp}=131.2-132.8^{\circ} \mathrm{C}$.

Procedure for the synthesis of C12-L-val-COOH (2a): L-valine methyl ester hydrochloride (1.74 g, 10.4 mmol, 1.0 eq.) was dissolved in chloroform ( $40 \mathrm{~mL})$. Triethylamine $\left(2.31 \mathrm{~g}, 22.9 \mathrm{mmol}, 2.2 \mathrm{eq}\right.$.) was added to the solution cooled at $0{ }^{\circ} \mathrm{C}$. Lauroyl chloride $(2.50 \mathrm{~g}, 11.4$ $\mathrm{mmol}, 1.1$ eq.) was then added dropwise to the solution and the reaction was stirred overnight. The reaction mixture was diluted with 
chloroform $\left(100 \mathrm{~mL}\right.$ ) and washed with $0.5 \mathrm{M} \mathrm{HCl}(250 \mathrm{~mL}), 10 \% \mathrm{NaHCO}_{3}$ aqueous solution $(250 \mathrm{~mL})$, and saturated brine, then dried over anhydrous $\mathrm{Na}_{2} \mathrm{SO}_{4}$. The solvent was removed by rotary evaporation and the crude product was used for the next reaction without further purification. The resulting crude intermediate $(1.88 \mathrm{~g}, 6.0 \mathrm{mmol}, 1.0$ eq.) was dissolved in methanol ( $12 \mathrm{~mL})$. Sodium hydroxide $(0.25 \mathrm{~g}, 6.3$ $\mathrm{mmol}, 1.1$ eq.) was dissolved in water $(6 \mathrm{~mL})$ and added to the solution, which was stirred overnight. The solvent was removed by rotary evaporation and the aqueous residue was then acidified with concentrated $\mathrm{HCl}$ until a $\mathrm{pH}$ value of 1 was achieved and the resulting mixture was extracted with diethyl ether $(3 \times 100 \mathrm{~mL})$. The organic extract was washed with saturated brine $(3 \times 70 \mathrm{~mL})$ and dried over anhydrous $\mathrm{Na}_{2} \mathrm{SO}_{4}$. The solvent was removed by rotary evaporation and the desired product was obtained as white solid ( $2.25 \mathrm{~g}, 7.9 \mathrm{mmol}, 72 \%$ yield). The crude product was dissolved in methanol and water was added dropwise until the product precipitated in solution and the resulting solvent mixture was used to facilitate recrystallization. ${ }^{1} \mathrm{H}$ NMR $\left(400 \mathrm{MHz}, \mathrm{CD}_{3} \mathrm{OD}\right): \delta 4.33(\mathrm{~d}, J=5.8 \mathrm{~Hz}, 1 \mathrm{H}), 2.28(\mathrm{t}, J=7.3 \mathrm{~Hz}, 2 \mathrm{H}), 2.23-$ $2.10(\mathrm{~m}, 1 \mathrm{H}), 1.68-1.54(\mathrm{~m}, 2 \mathrm{H}), 1.40-1.22(\mathrm{~m}, 16 \mathrm{H}), 0.79$ (dd, $J=4.6,2.2 \mathrm{~Hz}, 6 \mathrm{H}), 0.90(\mathrm{t}, J=6.5 \mathrm{~Hz}, 3 \mathrm{H}) .{ }^{13} \mathrm{C} \mathrm{NMR}\left(100 \mathrm{MHz}, \mathrm{CD}{ }_{3} \mathrm{OD}\right): \delta$ $176.1,174.5,58.5,36.3,32.7,31.2$ (2C), 30.3, 30.2 (2C), 30.1, 29.9, 26.7, 23.3, 19.2, 18.0, 14.0. EA calcd for $\mathrm{C}_{17} \mathrm{H}_{33} \mathrm{NO}_{3}$ : $\mathrm{N} \mathrm{4.68,} \mathrm{C} \mathrm{68.19,} \mathrm{H}$ 11.11, found $\mathrm{N} 4.71, \mathrm{C} 68.27, \mathrm{H}$ 11.11. $\mathrm{HRMS}(\mathrm{ES})$ calcd for $\mathrm{C}_{17} \mathrm{H}_{33} \mathrm{NO}_{3}(\mathrm{M}+\mathrm{H})^{+} 300.2542$, found 300.2542. $\mathrm{mp}=127.7-129.5^{\circ} \mathrm{C}$.

Procedure for the synthesis of C12-L-val-CONH $\mathbf{2}$ (2b): L-valinamide hydrochloride $(1.00 \mathrm{~g}, 6.6 \mathrm{mmol}, 1.0$ eq.) was dissolved in chloroform $(30 \mathrm{~mL})$. Triethylamine $\left(1.39 \mathrm{~g}, 1.4 \mathrm{mmol}, 2.1 \mathrm{eq}\right.$.) was added to the solution at $0{ }^{\circ} \mathrm{C}$. Lauroyl chloride $(1.58 \mathrm{~g}, 7.2 \mathrm{mmol}, 1.1 \mathrm{eq}$.) was then added dropwise to the solution and the solution was stirred overnight. The reaction mixture was diluted with chloroform (100 $\mathrm{mL})$ and washed with $1 \mathrm{M} \mathrm{HCl}(3 \times 70 \mathrm{~mL}), 10 \% \mathrm{NaHCO}_{3}$ aqueous solution $(3 \times 80 \mathrm{~mL})$, and saturated brine $(3 \times 70 \mathrm{~mL})$ and dried over anhydrous $\mathrm{Na}_{2} \mathrm{SO}_{4}$. The desired product was isolated by suction filtration as white solid $(1.60 \mathrm{~g}, 5.3 \mathrm{mmol}, 81 \%$ yield). The crude product was further purified by recrystallization in methanol. ${ }^{1} \mathrm{H}$ NMR $(400 \mathrm{MHz}, \mathrm{DMSO}): \delta 7.39(\mathrm{~d}, J=8.5 \mathrm{~Hz}, 1 \mathrm{H}), 7.09(\mathrm{br}, 1 \mathrm{H}), 6.74(\mathrm{br}, 1 \mathrm{H}), 4.12(\mathrm{dd}, J=6.4$, $2.5 \mathrm{~Hz}, 1 \mathrm{H}), 2.23-2.08(\mathrm{~m}, 2 \mathrm{H}), 2.04-1.91(\mathrm{~m}, 1 \mathrm{H}), 1.57,1.44(\mathrm{~m}, 2 \mathrm{H}), 1.34-1.19(\mathrm{~m}, 16 \mathrm{H}), 0.92-0.81(\mathrm{~m}, 9 \mathrm{H}) .{ }^{13} \mathrm{C} \mathrm{NMR}(100 \mathrm{MHz}, \mathrm{DMSO})$ : $\delta 173.3,172.2,57.6,35.4,31.3,30.2,29.0(2 \mathrm{C}), 28.9,28.8,28.7,28.6(2 \mathrm{C}), 25.4,22.2,19.3,18.0,13.8$. EA calcd for $\mathrm{C}_{17} \mathrm{H}_{34} \mathrm{~N}_{2} \mathrm{O}_{2}: \mathrm{N}_{9.39}, \mathrm{C}$ 68.41, $\mathrm{H}$ 11.48, found N 9.43, C 68.77, $\mathrm{H}$ 11.41. HRMS(ES) calcd for $\mathrm{C}_{17} \mathrm{H}_{34} \mathrm{~N}_{2} \mathrm{O}_{2}(\mathrm{M}+\mathrm{H})^{+} 299.2699$, found 299.2696. $\mathrm{mp}=170.0-171.5^{\circ} \mathrm{C}$.

Procedure for the synthesis of C12-L-leu-COOH (3a): L-leucine methyl ester hydrochloride (1.89 g, 10.4 mmol, 1.0 eq.) was dissolved in chloroform $(40 \mathrm{~mL})$. Triethylamine $\left(2.31 \mathrm{~g}, 22.9 \mathrm{mmol}, 2.2 \mathrm{eq}\right.$.) was added to the solution cooled at $0^{\circ} \mathrm{C}$. Lauroyl chloride $(2.50 \mathrm{~g}, 11.4 \mathrm{mmol}$, 1.1 eq.) was then added dropwise to the solution and the reaction mixture was stirred overnight. The reaction mixture was diluted with chloroform and washed with $0.5 \mathrm{M} \mathrm{HCl}(250 \mathrm{~mL}), 10 \% \mathrm{NaHCO}_{3}$ aqueous solution $(250 \mathrm{~mL})$, and saturated brine $(250 \mathrm{~mL})$ and dried over anhydrous $\mathrm{Na}_{2} \mathrm{SO}_{4}$. The solvent was removed by rotary evaporation and the crude product was used for the next reaction without further purification. The resulting crude intermediate $(1.97 \mathrm{~g}, 6.0 \mathrm{mmol}, 1.0 \mathrm{eq}$.) was dissolved in methanol (12 $\mathrm{mL})$. Sodium hydroxide $(0.25 \mathrm{~g}$, 6.3 $\mathrm{mmol}, 1.1$ eq.) was dissolved in water $(6 \mathrm{~mL})$ and added to the reaction mixture, which was stirred overnight. The solvent was removed by rotary evaporation and the aqueous residue was acidified with concentrated $\mathrm{HCl}$ until a $\mathrm{pH}$ value of 1 was achieved and then the resulting mixture was extracted with diethyl ether $(3 \times 100 \mathrm{~mL})$. The organic extract was washed with saturated brine $(3 \times 100 \mathrm{~mL})$ and dried over anhydrous $\mathrm{Na}_{2} \mathrm{SO}_{4}$. The solvent was removed by rotary evaporation and the desired product was obtained as white solid ( $2.84 \mathrm{~g}, 9.0 \mathrm{mmol}$, $87 \%$ yield). The crude product was dissolved in methanol and water was added dropwise until the product precipitated in solution and the resulting solvent mixture was used to facilitate recrystallization. ${ }^{1} \mathrm{H} \mathrm{NMR}\left(400 \mathrm{MHz}, \mathrm{CDCl}_{3}\right): \delta 5.87(\mathrm{~d}, J=7.7 \mathrm{~Hz}, 1 \mathrm{H}), 4.61(\mathrm{dt}, J=4.8,8.6$ $\mathrm{Hz}, 1 \mathrm{H}), 2.24(\mathrm{t}, J=7.2 \mathrm{~Hz}, 2 \mathrm{H}), 1.80-1.52(\mathrm{~m}, 5 \mathrm{H}), 1.35-1.20(\mathrm{~m}, 16 \mathrm{H}), 0.96(\mathrm{~d}, J=6.3 \mathrm{~Hz}, 3 \mathrm{H}), 0.95(\mathrm{~d}, J=6.3 \mathrm{~Hz}, 3 \mathrm{H}), 0.88(\mathrm{t}, J=6.5 \mathrm{~Hz}$, 3H). ${ }^{13} \mathrm{C}$ NMR $\left(100 \mathrm{MHz}, \mathrm{CDCl}_{3}\right) \delta 176.2,174.3,51.1,41.2,36.6,32.1,29.8,29.6,29.5,29.3,25.7,25.0,23.0,22.8,22.0,14.3$. EA calcd for $\mathrm{C}_{18} \mathrm{H}_{35} \mathrm{NO}_{3}: \mathrm{N} 4.47, \mathrm{C} 68.97, \mathrm{H} 11.25$, found $\mathrm{N} 4.54, \mathrm{C} 69.22, \mathrm{H} 11.19$. HRMS(ES) calcd for $\mathrm{C}_{17} \mathrm{H}_{34} \mathrm{NO}_{3}(\mathrm{M}+\mathrm{H})^{+} 314.2695$, found 314.2692. mp $=103.7-105 \cdot 5^{\circ} \mathrm{C}$.

Procedure for the synthesis of C12-L-leu-CONH $\mathbf{2}(3 \mathbf{b})$ : L-leucinamide hydrochloride $(1.00 \mathrm{~g}, 6.0 \mathrm{mmol}, 1.0$ eq.) was dissolved in chloroform $(30 \mathrm{~mL})$. Triethylamine $\left(1.28 \mathrm{~g}, 12.6 \mathrm{mmol}, 2.1 \mathrm{eq}\right.$.) was added to the solution at $0{ }^{\circ} \mathrm{C}$. Lauroyl chloride $(1.44 \mathrm{~g}, 6.6 \mathrm{mmol}, 1.1 \mathrm{eq}$.) was then added dropwise to the solution and the solution was stirred overnight. The reaction mixture was diluted with chloroform (100 $\mathrm{mL})$ and washed with $1 \mathrm{M} \mathrm{HCl}(3 \times 70 \mathrm{~mL}), 10 \% \mathrm{NaHCO}_{3}$ aqueous solution $(3 \times 80 \mathrm{~mL})$, and saturated brine $(3 \times 70 \mathrm{~mL})$ and dried over anhydrous $\mathrm{Na}_{2} \mathrm{SO}_{4}$. The solvent was removed by rotary evaporation and the desired product was obtained as white solid ( $1.63 \mathrm{~g}, 5.2 \mathrm{mmol}, 87 \%$ yield). The crude product was dissolved in methanol and water was added dropwise until the product precipitated in solution and then the solvent mixture was used to facilitate recrystallization. ${ }^{1} \mathrm{H} \mathrm{NMR}\left(400 \mathrm{MHz}, \mathrm{DMSO}-\mathrm{d}_{6}\right): \delta 7.79(\mathrm{~d}, J=8.4 \mathrm{~Hz}, 1 \mathrm{H}), 7.27(\mathrm{br}, 1 \mathrm{H}), 6.89(\mathrm{br}, 1 \mathrm{H}), 4.22(\mathrm{dt}$, $J=8.3,7.3 \mathrm{~Hz}, 1 \mathrm{H}), 2.09(\mathrm{dt}, J=3.8,7.5 \mathrm{~Hz}, 2 \mathrm{H}), 1.65-1.41(\mathrm{~m}, 5 \mathrm{H}), 1.32-1.15(\mathrm{~m}, 16 \mathrm{H}), 1.16(\mathrm{~d}, J=7.1 \mathrm{~Hz}, 3 \mathrm{H}), 0.89-0.80(\mathrm{~m}, 9 \mathrm{H}) .{ }^{13} \mathrm{C} \mathrm{NMR}$ $\left(100 \mathrm{MHz}, \mathrm{DMSO}-\mathrm{d}_{6}\right): \delta 174.4,172.0,50.6,40.9,35.2,31.3,29.0,28.7(2 \mathrm{C}), 28.5,25.2,24.3,23.0,22.1,21.4,13.9$. EA calcd for $\mathrm{C}_{18} \mathrm{H}_{36} \mathrm{~N}_{2} \mathrm{O}_{2}$ : $\mathrm{N} 8.96, \mathrm{C} 69.18, \mathrm{H} 11.61$, found $\mathrm{N} 8.82, \mathrm{C} 69.18, \mathrm{H}$ 11.61. HRMS(ES) calcd for $\mathrm{C}_{18} \mathrm{H}_{36} \mathrm{~N}_{2} \mathrm{O}_{2}(\mathrm{M}+\mathrm{Na})^{+} 335.2674$, found 335.2677. $\mathrm{mp}=102.5-$ $104.0^{\circ} \mathrm{C}$

Procedure for the synthesis of C12-L-phe-COOH (4a): L-phenylalanine methyl ester hydrochloride (1.00 g, $4.6 \mathrm{mmol}, 1.0 \mathrm{eq}$.) was dissolved in chloroform ( $30 \mathrm{~mL})$. Triethylamine $\left(1.17 \mathrm{~g}, 11.6 \mathrm{mmol}, 2.5\right.$ eq.) was added to the solution at $0{ }^{\circ} \mathrm{C}$. Lauroyl chloride $(1.12 \mathrm{~g}, 5.12 \mathrm{mmol}$, 1.1 eq.) was then added dropwise to the solution and the solution was stirred overnight. The reaction mixture was diluted with chloroform $(50 \mathrm{~mL})$ and washed with $1 \mathrm{M} \mathrm{HCl}(3 \times 80 \mathrm{~mL}), 10 \% \mathrm{NaHCO}_{3}$ aqueous solution $(3 \times 90 \mathrm{~mL})$, and saturated brine $(3 \times 80 \mathrm{~mL})$ and dried over anhydrous $\mathrm{Na}_{2} \mathrm{SO}_{4}$. The solvent was removed by rotary evaporation and the crude product was used for the next reaction without further purification. The resulting crude intermediate ( $1.78 \mathrm{~g}, 4.9 \mathrm{mmol}, 1.0$ eq.) was dissolved in methanol ( $30 \mathrm{~mL})$. Sodium hydroxide ( $0.26 \mathrm{~g}$, 6.5 $\mathrm{mmol}, 1.3$ eq.) was added to the solution and the solution was stirred overnight. The reaction mixture was diluted with water ( $15 \mathrm{~mL})$ and the solvent was removed by rotary evaporation. The aqueous residue was acidified with concentrated $\mathrm{HCl}$ to a $\mathrm{pH}$ value of 1 and the resulting mixture was extracted with diethyl ether $(3 \times 90 \mathrm{~mL})$ and dried over anhydrous $\mathrm{Na}_{2} \mathrm{SO}_{4}$. The solvent was removed by rotary evaporation and the desired product was obtained as white solid ( $1.49 \mathrm{~g}, 4.3 \mathrm{mmol}, 93 \%$ yield). The resulting solid was further purified by 
recrystallization in 1:4 water:isopropanol. ${ }^{1} \mathrm{H}$ NMR $\left(400 \mathrm{MHz}, \mathrm{CD}_{3} \mathrm{OD}\right): \delta 7.31-7.20(\mathrm{~m}, 5 \mathrm{H}), 7.41(\mathrm{dt}, J=4.8,9.6 \mathrm{~Hz}, 1 \mathrm{H}), 3.25(\mathrm{dd}, J=14.5$, $5.0 \mathrm{~Hz}, 1 \mathrm{H}), 2.96(\mathrm{dd}, J=13.9,4.4 \mathrm{~Hz}, 1 \mathrm{H}), 2.17(\mathrm{t}, J=7.4 \mathrm{~Hz}, 2 \mathrm{H}), 1.55-1.47(\mathrm{~m}, 2 \mathrm{H}), 1.40-1.26(\mathrm{~m}, 16 \mathrm{H}), 0.93(\mathrm{t}, J=6.4 \mathrm{~Hz}, 3 \mathrm{H}) .{ }^{13} \mathrm{C} \mathrm{NMR}$ (100 MHz, CD $\left.{ }_{3} \mathrm{OD}\right): 174.8,173.5,137.2,128.9,128.0,126.3,53.5,37.0,35.4,31.7,29.4$ (2C), 29.2, 29.1 (2C), 28.7, 25.5, 22.4, 13.1. EA calcd for $\mathrm{C}_{21} \mathrm{H}_{33} \mathrm{NO}_{3}$ : N 4.03, C 72.58, $\mathrm{H}$ 9.57, found N 3.80, C 72.53, H 9.64. HRMS(ES) calcd for $\mathrm{C}_{21} \mathrm{H}_{33} \mathrm{NO}_{3}(\mathrm{M}+\mathrm{H})^{+} 348.2539$, found 348.2532 . $\mathrm{mp}=86.5-89.0^{\circ} \mathrm{C}$.

Procedure for the synthesis of C12-L-phe-CONH $\mathbf{~ ( 4 b ) : ~ L - p h e n y l a l a n i n a m i d e ~ ( ~} 2.00 \mathrm{~g}, 12.2 \mathrm{mmol}, 1.0$ eq.) was dissolved in chloroform (50 $\mathrm{mL}$ ). Triethylamine (1.36 g, $13.4 \mathrm{mmol}, 1.1 \mathrm{eq}$.) was added to the solution at $0{ }^{\circ} \mathrm{C}$. Lauroyl chloride $(2.93 \mathrm{~g}, 13.4 \mathrm{mmol}, 1.1 \mathrm{eq}$.) was then added dropwise to the solution and the solution was stirred overnight. The reaction mixture was diluted with $\mathrm{chloroform} \mathrm{(100} \mathrm{mL})$ and washed with $1 \mathrm{M} \mathrm{HCl}(3 \times 70 \mathrm{~mL}), 10 \% \mathrm{NaHCO}_{3}$ aqueous solution $(3 \times 80 \mathrm{~mL})$, and saturated brine $(3 \times 70 \mathrm{~mL})$ and dried over anhydrous $\mathrm{Na}_{2} \mathrm{SO}_{4}$. The reaction mixture was isolated by suction filtration as white solid $(2.70 \mathrm{~g}, 7.8 \mathrm{mmol}, 64 \%$ yield). The crude product was further purified by recrystallization in methanol. ${ }^{1} \mathrm{H}$ NMR $\left(400 \mathrm{MHz}, \mathrm{CDCl}_{3}\right): \delta 7.30-7.22(\mathrm{~m}, 5 \mathrm{H}), 6.20-6.14(\mathrm{~m}, 1 \mathrm{H}), 6.00(\mathrm{br}, 1 \mathrm{H}), 5.48(\mathrm{br}, 1 \mathrm{H}), 4.72$ $(\mathrm{dt}, J=14.6,7.2 \mathrm{~Hz}, 1 \mathrm{H}), 3.08(\mathrm{~d}, J=7.2 \mathrm{~Hz}, 2 \mathrm{H}), 2.15(\mathrm{t}, J=7.5 \mathrm{~Hz}, 2 \mathrm{H}), 1.61-1.49(\mathrm{~m}, 2 \mathrm{H}), 1.33-1.26(\mathrm{~m}, 16 \mathrm{H}), 0.89(\mathrm{t}, J=6.8 \mathrm{~Hz}, 3 \mathrm{H}) .{ }^{13} \mathrm{C}$ NMR $\left(100 \mathrm{MHz}, \mathrm{CDCl}_{3}\right): \delta 173.3,173.2,136.7,129.3,128.6,127.0,53.9,38.2,36.5,31.9,29.5$ (2C), 29.4, 29.3, 29.1, 25.5, 22.6, 13.9. EA calcd for $\mathrm{C}_{21} \mathrm{H}_{34} \mathrm{~N}_{2} \mathrm{O}_{2}$ : N 8.08, C 72.79, $\mathrm{H} 9.89$, found $\mathrm{N}$ 8.14, C 73.18, H 9.88. HRMS(ES) calcd for $\mathrm{C}_{21} \mathrm{H}_{34} \mathrm{~N}_{2} \mathrm{O}_{2}(\mathrm{M}+\mathrm{Na})^{+} 369.2518$, found 369.2520. $\mathrm{mp}=147.8-150.1^{\circ} \mathrm{C}$. 
a.
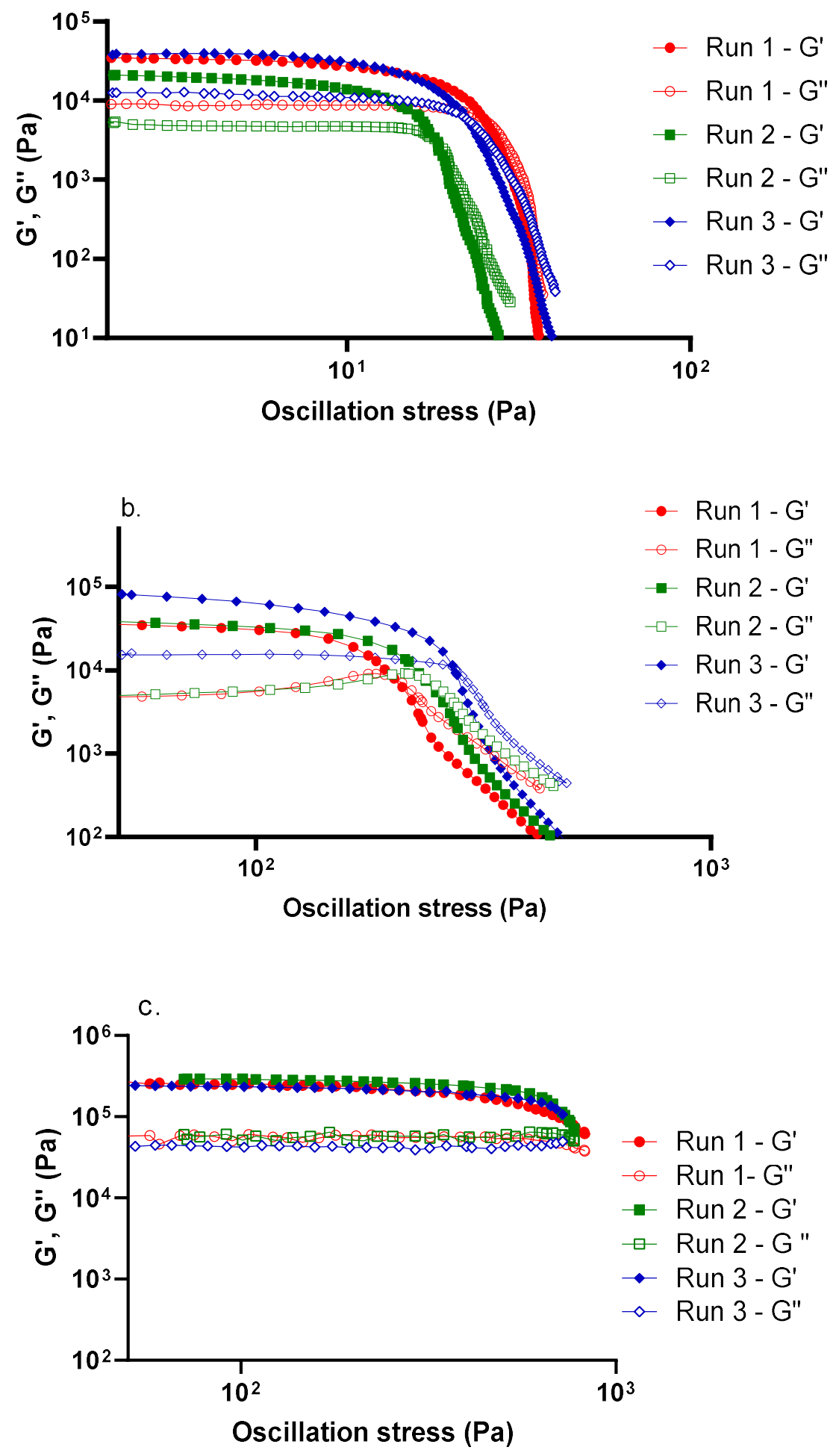

Figure S2. a) Amplitude sweep of the decane gel containing $5.0 \% \mathrm{w} / \mathrm{v}$ gelator $1 \mathrm{a}$. b) Amplitude sweep of the decane gel containing $2.5 \%$ w/v gelator $\mathbf{1 b}$. c) Amplitude sweep of the decane gel containing $5.0 \% \mathrm{w} / \mathrm{v}$ gelator $\mathbf{1} \mathbf{b}$. 


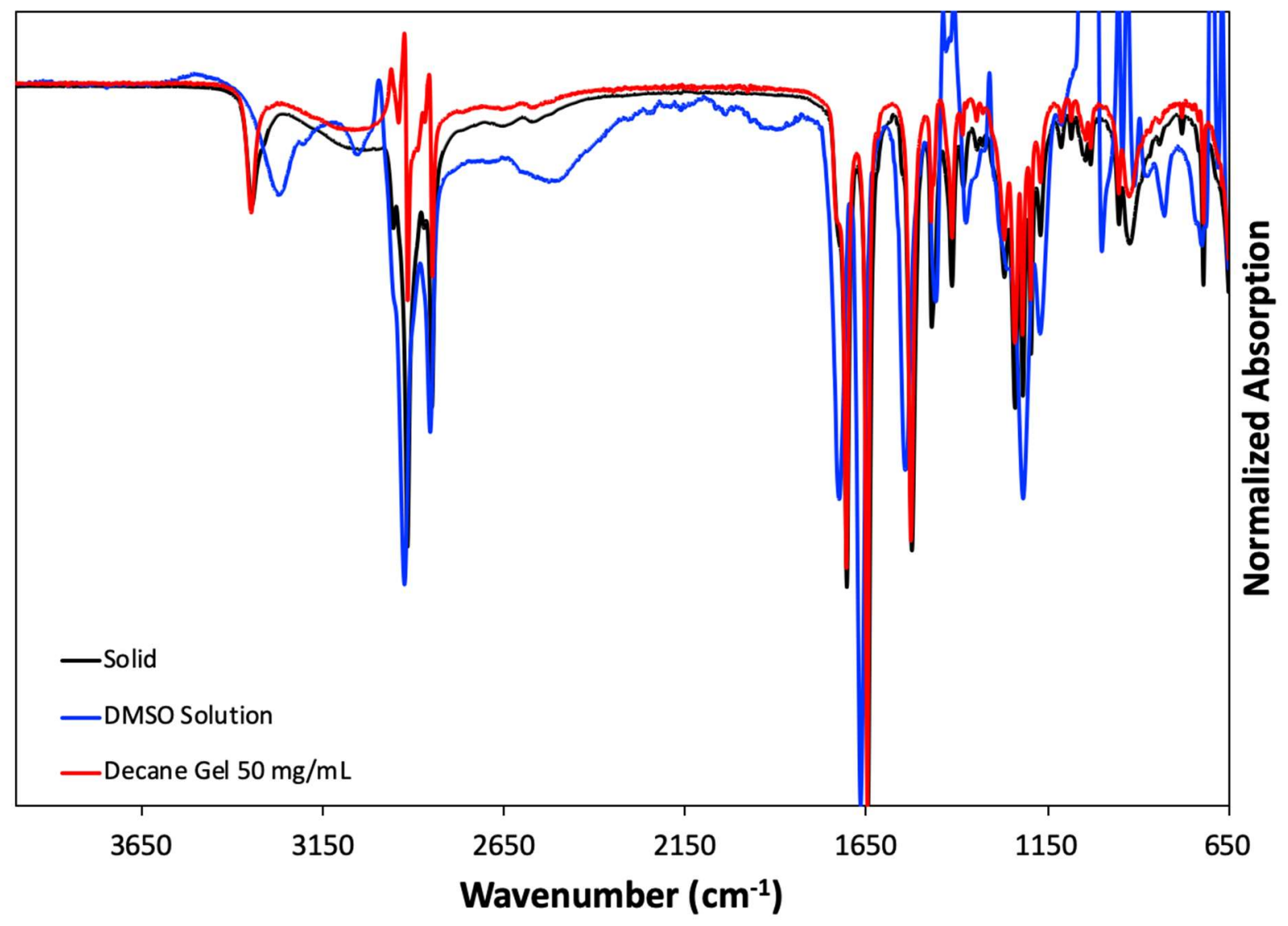

Figure S3. FT-IR spectra of C12-L-ala-COOH 1a as solid (black line), as a DMSO solution (blue line) and as a decane gel at $5.0 \% \mathrm{w} / \mathrm{v}$ (red line). Carbonyl stretching frequencies are 1648 and $1705 \mathrm{~cm}^{-1}$ for the solid and decane gel (black and red), and 1665 and $1724 \mathrm{~cm}^{-1} \mathrm{for}$ the DMSO solution (blue). 


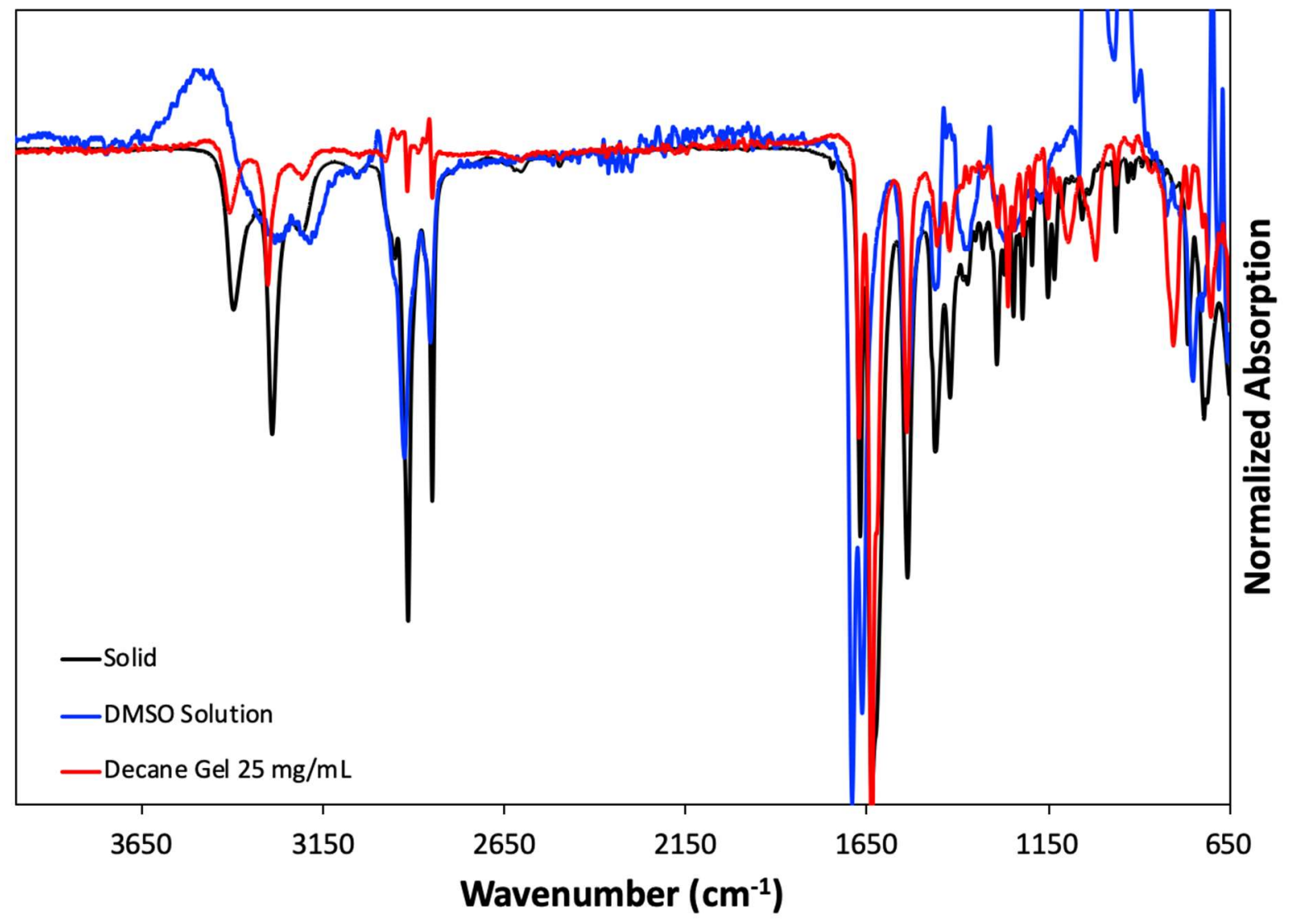

Figure S4. FT-IR spectra of C12-L-ala-CONH $\mathbf{1} \mathbf{1 b}$ as solid (black line), as a DMSO solution (blue line) and as a decane gel at $2.5 \% \mathrm{w} / \mathrm{v}$ (red line). Carbonyl stretching frequencies are 1640 and $1668 \mathrm{~cm}^{-1}$ for the solid (black), 1663 and $1691 \mathrm{~cm}^{-1}$ for the DMSO solution (blue), and 1634 and $1672 \mathrm{~cm}^{-1}$ for the decane gel (red). 


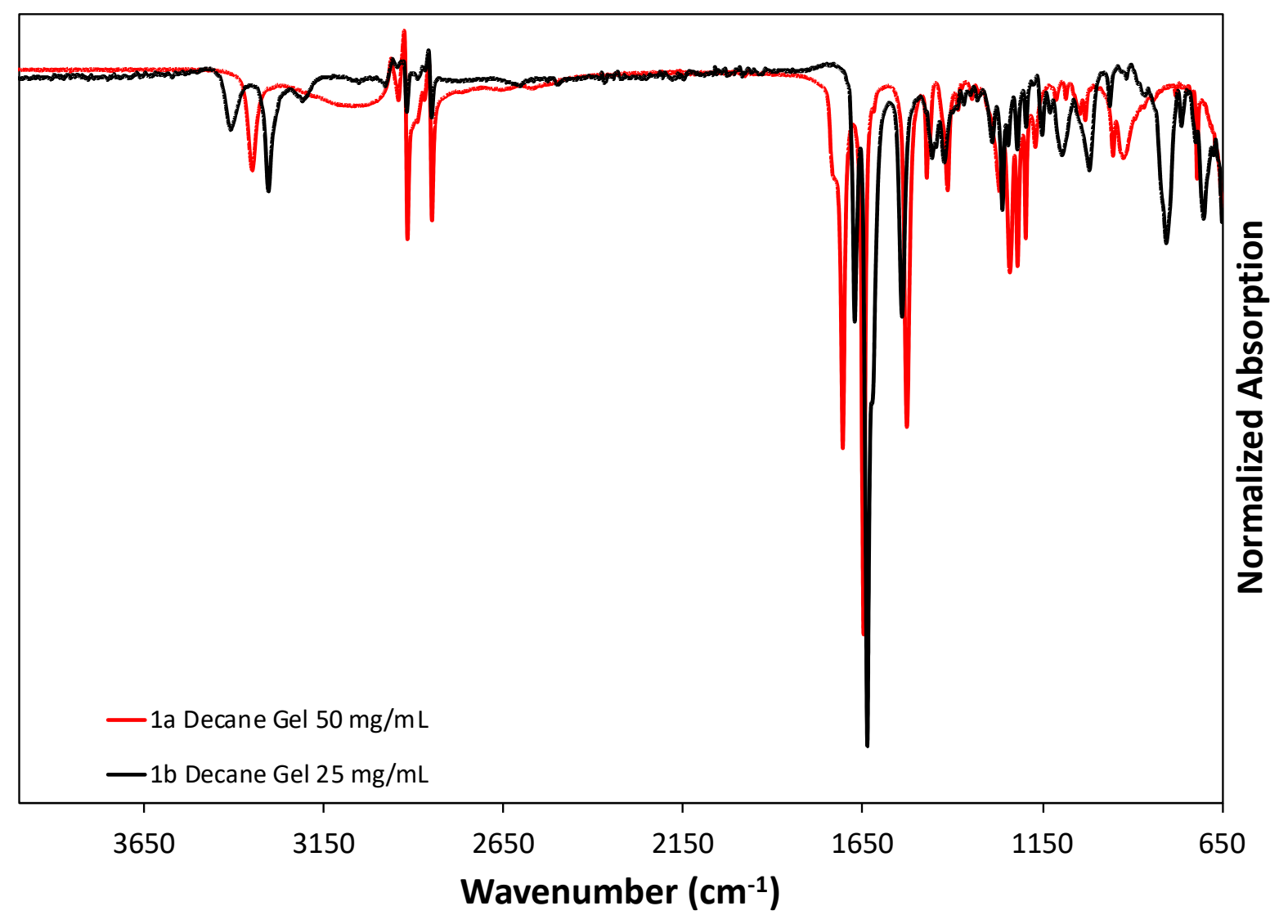

Figure S5. FT-IR spectra of C12-L-ala-COOH 1a as a decane gel $5 \% \mathrm{w} / \mathrm{v}$ (red line) and C12-L-ala-CONH 2 $\mathbf{1 b}$ as decane gel at $2.5 \% \mathrm{w} / \mathrm{v}$ (black line). Carbonyl stretching frequencies are 1648 and $1705 \mathrm{~cm}^{-1}$ for $1 \mathrm{a}$, and 1634 and $1672 \mathrm{~cm}^{-1}$ for $\mathbf{1 b}$. 


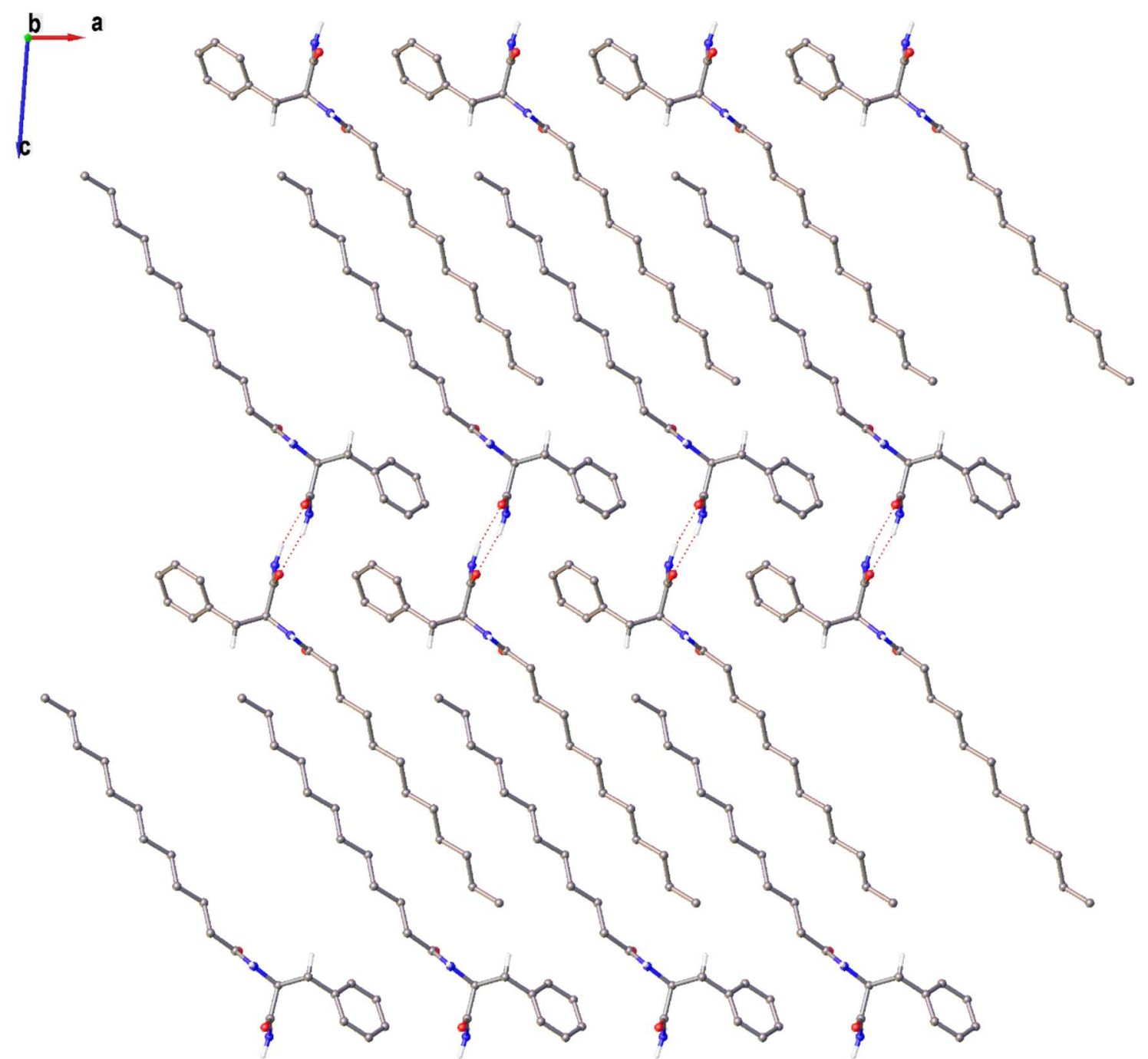

Figure S6. Crystal packing along $b$ for compound $\mathbf{4 b}$. 


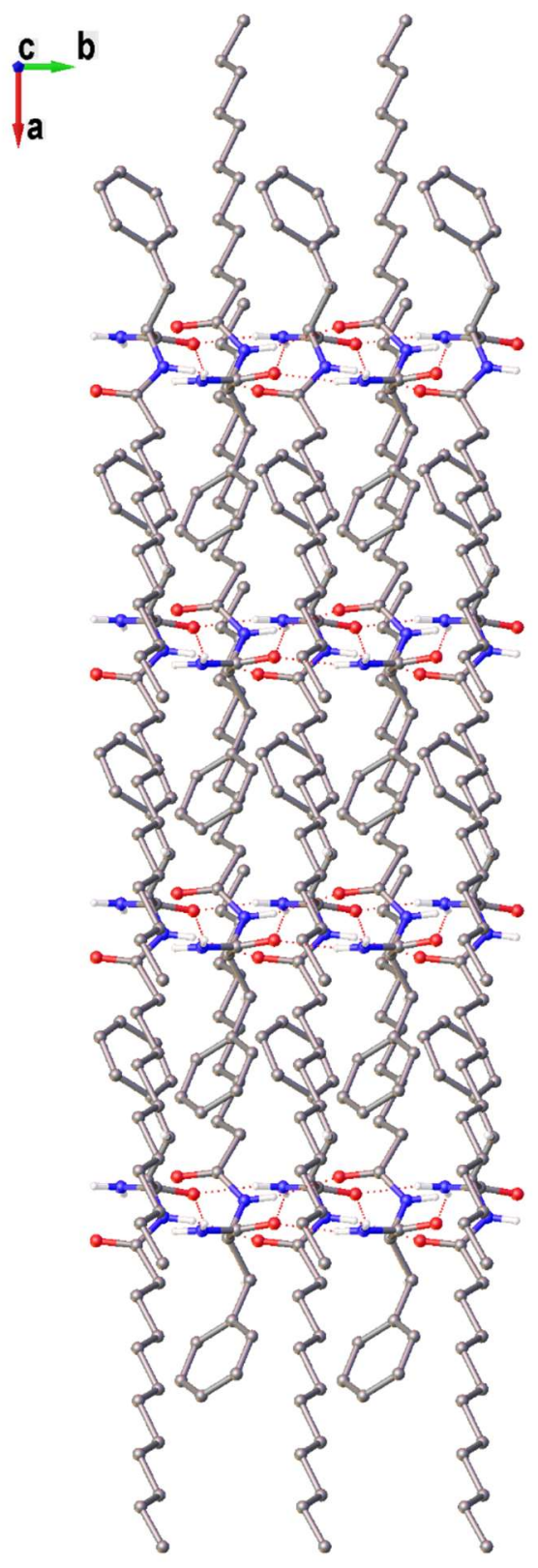

Figure S7. Crystal packing along $c$ for compound $\mathbf{4 b .}$ 
Samples were dissolved in $\mathrm{MeOH}$ and heated with a heat gun (to $\sim 70{ }^{\circ} \mathrm{C}$ ) until fully dissolved. The working solutions were $\sim 1 \mathrm{mg} / \mathrm{mL}$. Flow rate: $20 \mu \mathrm{L} / \mathrm{min}$; sample cone: $90 \mathrm{~V}$; source temperature: $120{ }^{\circ} \mathrm{C}$; desolvation temperature: $120{ }^{\circ} \mathrm{C}$. For accurate mass measurements a reference compound was used and the mass locked, see the Table S2 for more details.

Table S2. Summary of HRMS data for compounds 1-4.

\begin{tabular}{|c|c|c|c|}
\hline Number & Compound & Reference Compound & Mass Lock \\
\hline $1 \mathrm{a}$ & $\mathrm{C}_{12}$-L-ala-COOH & lys-lys & 275.2093 \\
\hline $1 b$ & $\mathrm{C}_{12}$-L-ala-CONH $\mathrm{H}_{2}$ & lys-lys & 275.2093 \\
\hline $2 a$ & $\mathrm{C}_{12}$-L-val-COOH & arg-lys & 303.2144 \\
\hline $2 b$ & $\mathrm{C}_{12}$-L-val-CONH $\mathrm{H}_{2}$ & arg-lys & 303.2144 \\
\hline $3 a$ & $\mathrm{C}_{12}$-L-leu-COOH & arg-phe & 322.1879 \\
\hline $3 b$ & $\mathrm{C}_{12}$-L-leu-CONH${ }_{2}$ & arg-gly-asp & 347.1979 \\
\hline $4 a$ & $\mathrm{C}_{12}$-L-phe- $\mathrm{COOH}$ & arg-phe & 322.1879 \\
\hline $4 b$ & $\mathrm{C}_{12}$-L-phe-CONH${ }_{2}$ & haloperidol & 376.1479 \\
\hline 1c & $\mathrm{C}_{12}$-D-ala-CONH${ }_{2}$ & lys-lys & 275.2093 \\
\hline $1 d$ & $\mathrm{C}_{12}$-DL-ala-CONH & lys-lys & 275.2093 \\
\hline
\end{tabular}

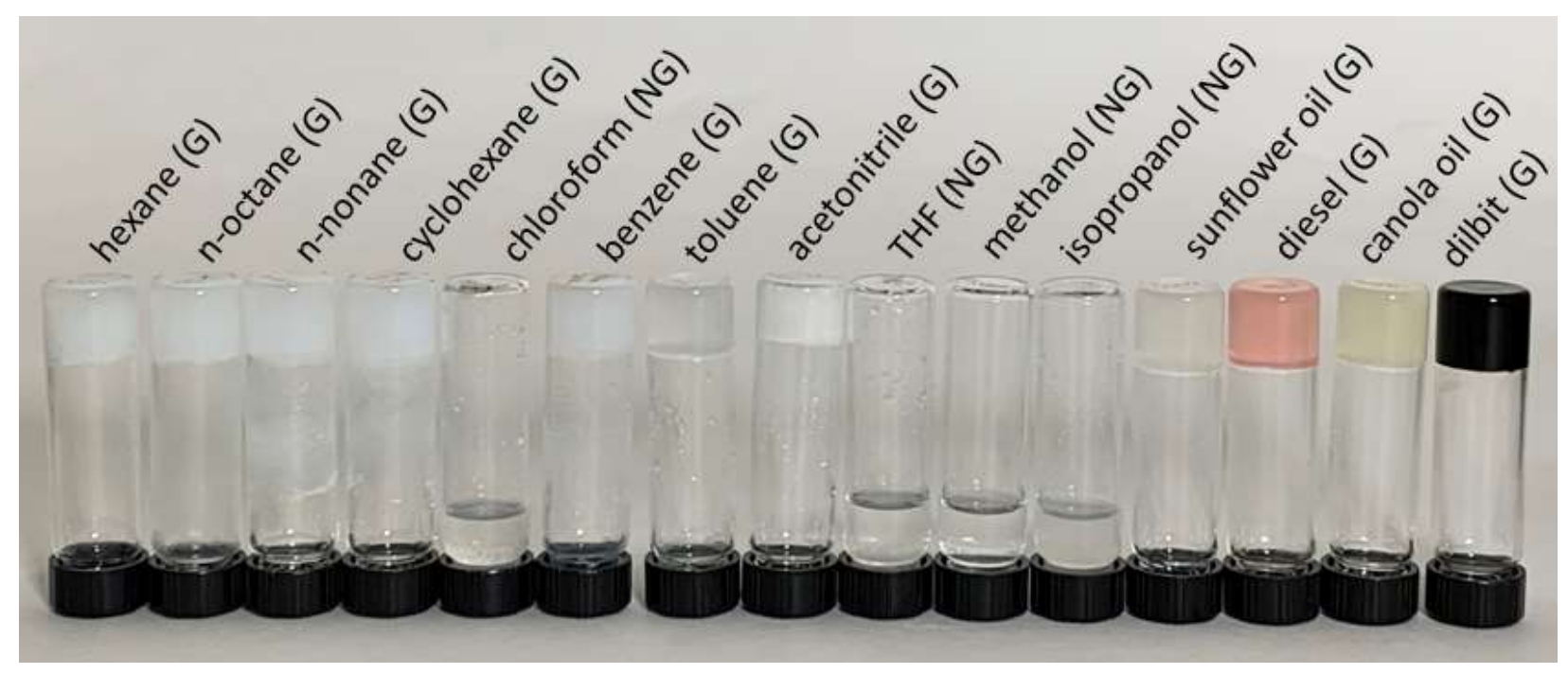

Figure S8. Vial inversion test for gels of $1.25 \% \mathrm{w} / \mathrm{v}$ of $\mathrm{C} 12$-L-ala-CONH${ }_{2}, \mathbf{1 b}$ in different solvents. 

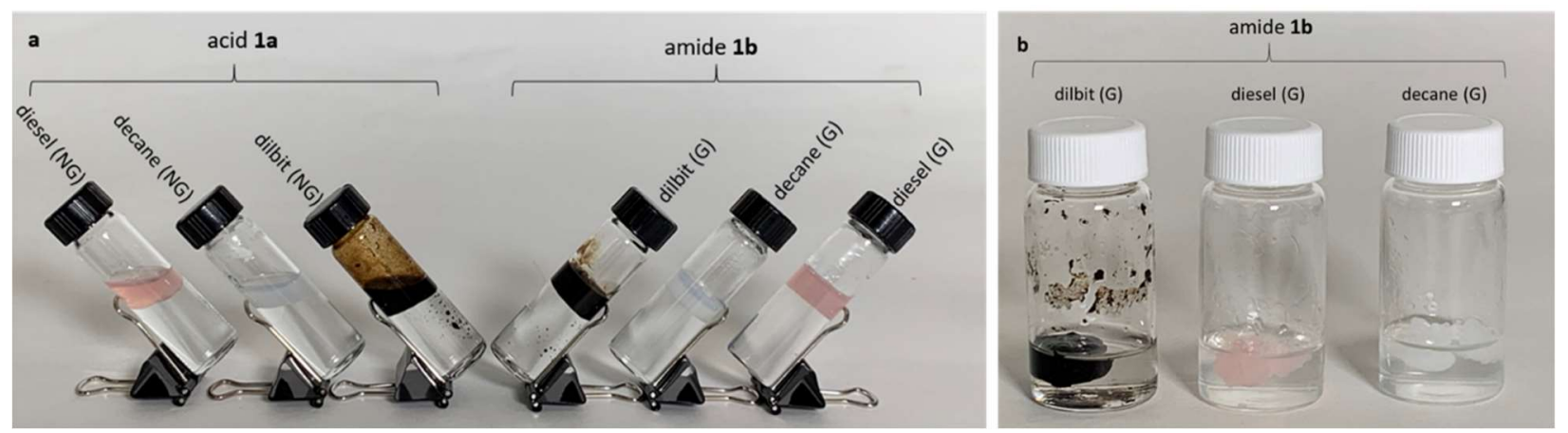

Figure S9. a) Phase-selective gelation of $\mathrm{C} 12-\mathrm{L}-\mathrm{ala}-\mathrm{COOH}(\mathbf{1 a})$ vs $\mathrm{C} 12-\mathrm{L}$-ala- $\mathrm{CONH}_{2}$ (1) ) via thermal delivery with $0.5 \%$ w/v gelator. b) $\mathrm{C} 12-\mathrm{L}$-ala-CONH 2 (1b) with IPA delivery $(1.25 \% \mathrm{w} / \mathrm{v})$ in dilbit, red diesel and decane. The retention of phase-selective gelation ability by the amide indicates that the presence of water does not interfere with any hydrogen bonding interactions during the self-assembly process.

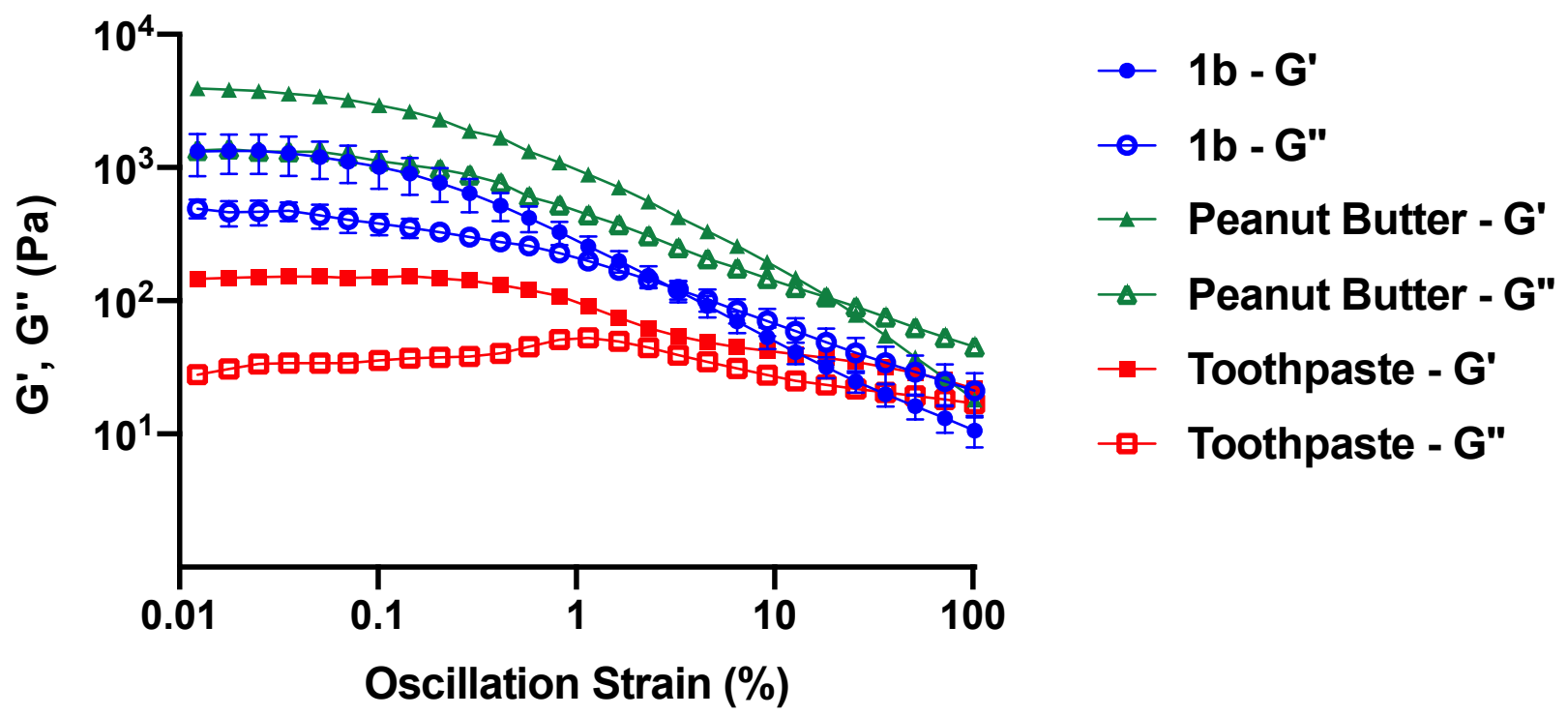

Figure S10. Amplitude sweep of the decane gel using water-based delivery system containing $2.5 \% \mathrm{w} / \mathrm{v}$ gelator $\mathbf{1 b}$, peanut butter and toothpaste. 


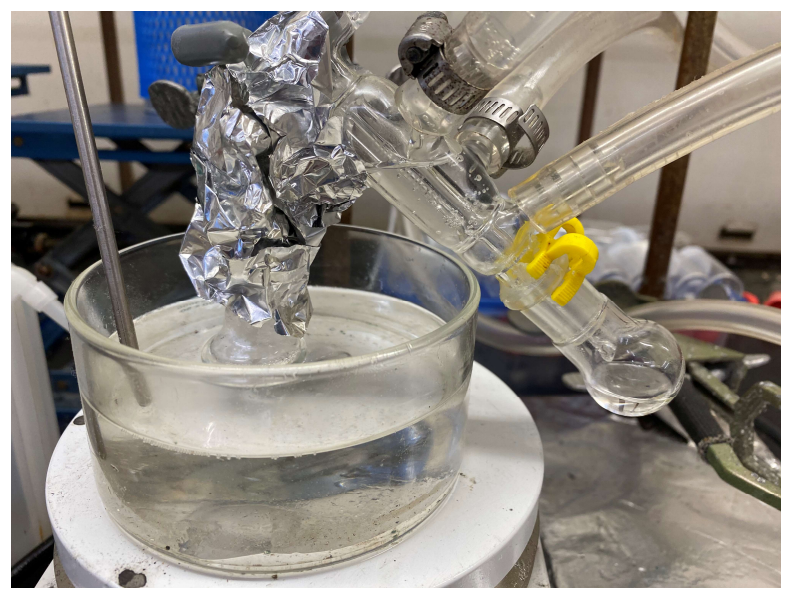

Figure S11. Image of vacuum distillation setup used to recover decane from the decane gel of $\mathbf{1 b}$.
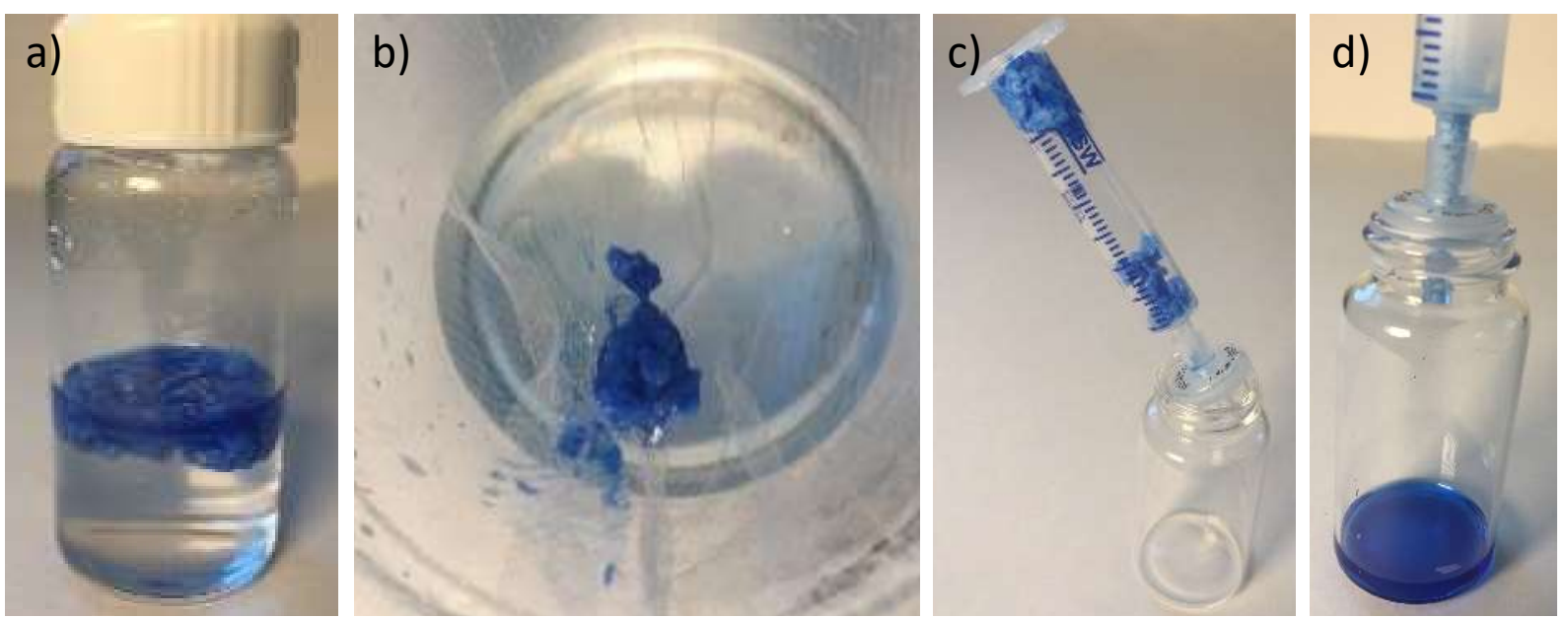

Figure S12. Photos of the syringe filter recovery method. a) Gel formed by the addition of oil blue dyed decane $(2.0 \% \mathrm{w} / \mathrm{v})$ to the aqueous network of $\mathbf{1 b}(5 \mathrm{mg} / \mathrm{mL})$, b) filtering of gel with nylon screen filter, c) loading of the gel into the syringe, d) filtering of the gel to recover the dyed decane. 


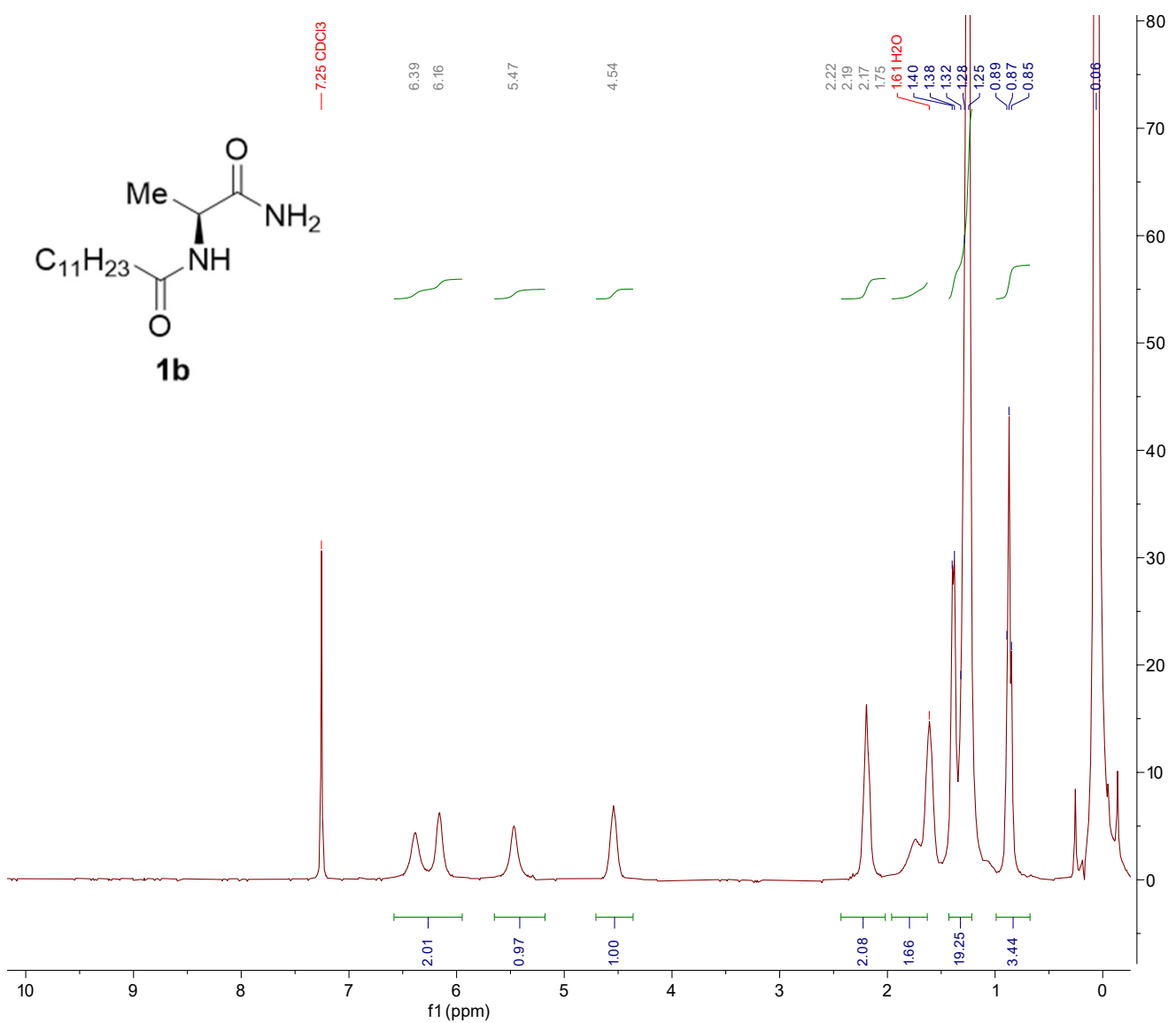

Figure S13. ${ }^{1} \mathrm{H}$ NMR $\left(300 \mathrm{MHz} C D C l_{3}\right.$ ) spectrum of gelator residue of $\mathbf{1} \mathbf{b}$ after distillation. The spectrum is agreement with pure 1b (Figure S16).

Supporting Video S1: CLSM Z-stack of the decane gel of $\mathbf{1 b}$ at $2.5 \% \mathrm{w} / \mathrm{v}$ doped with Nile red.

Supporting Video S2: CLSM Z-stack of the aqueous network of $\mathbf{1 b}$ at $5 \mathrm{mg} / \mathrm{mL}$ doped with crystal violet.

Supporting Video S3: Video of the addition of oil blue dyed decane $(1 \mathrm{~mL}, 2.0 \% \mathrm{w} / \mathrm{v})$ to the aqueous network of $1 \mathbf{b}(5 \mathrm{mg} / \mathrm{mL})$ doped with rhodamine $B$ and $4 \mathrm{~mL}$ of water. 


\section{$\mathrm{C}_{12}$-L-ala-COOH (1a)}

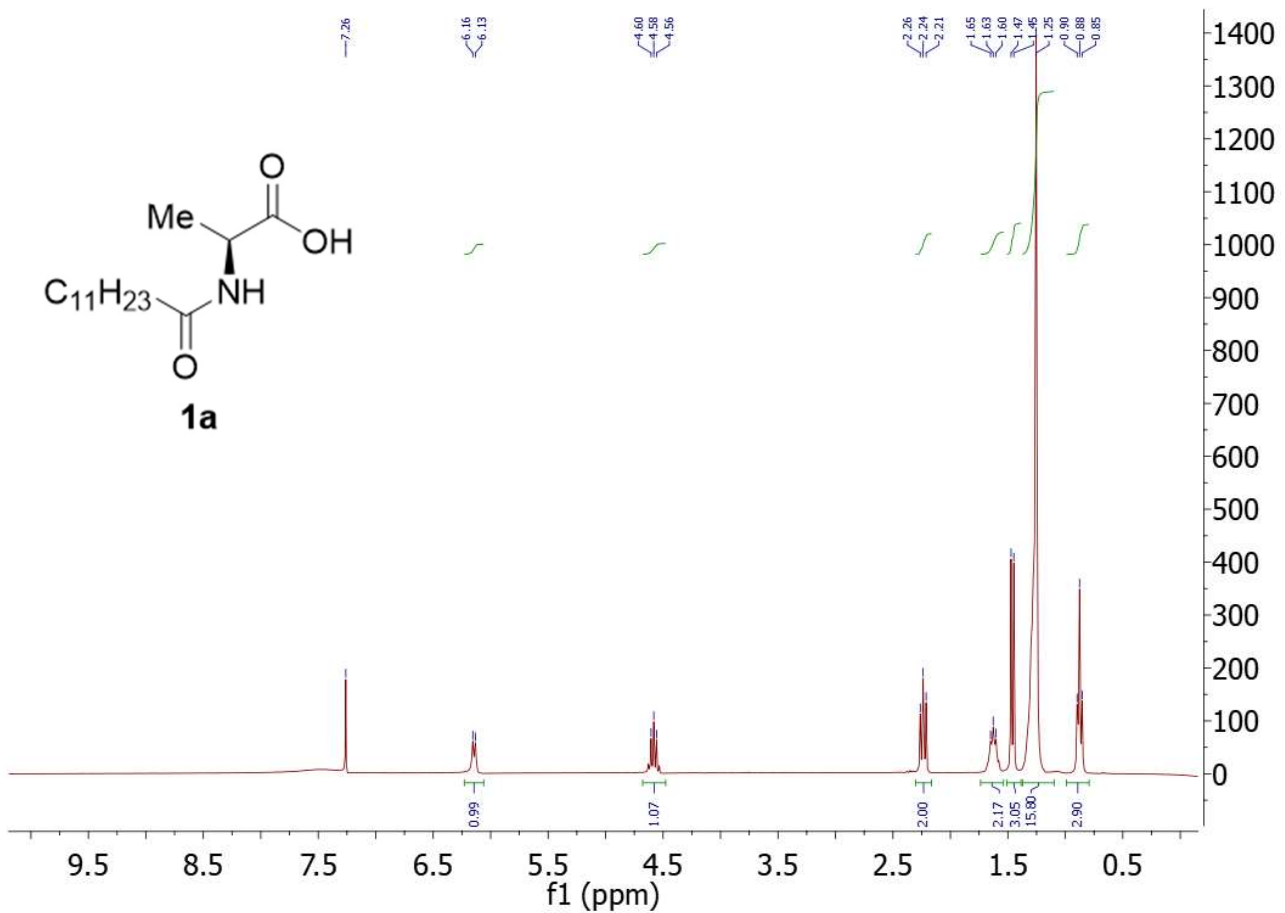

Figure S14. ${ }^{1 \mathrm{H}} \mathrm{NMR}$ spectrum $\left(400 \mathrm{MHz}, \mathrm{CDCl}_{3}\right.$ ) of compound $\mathbf{1 a}$.

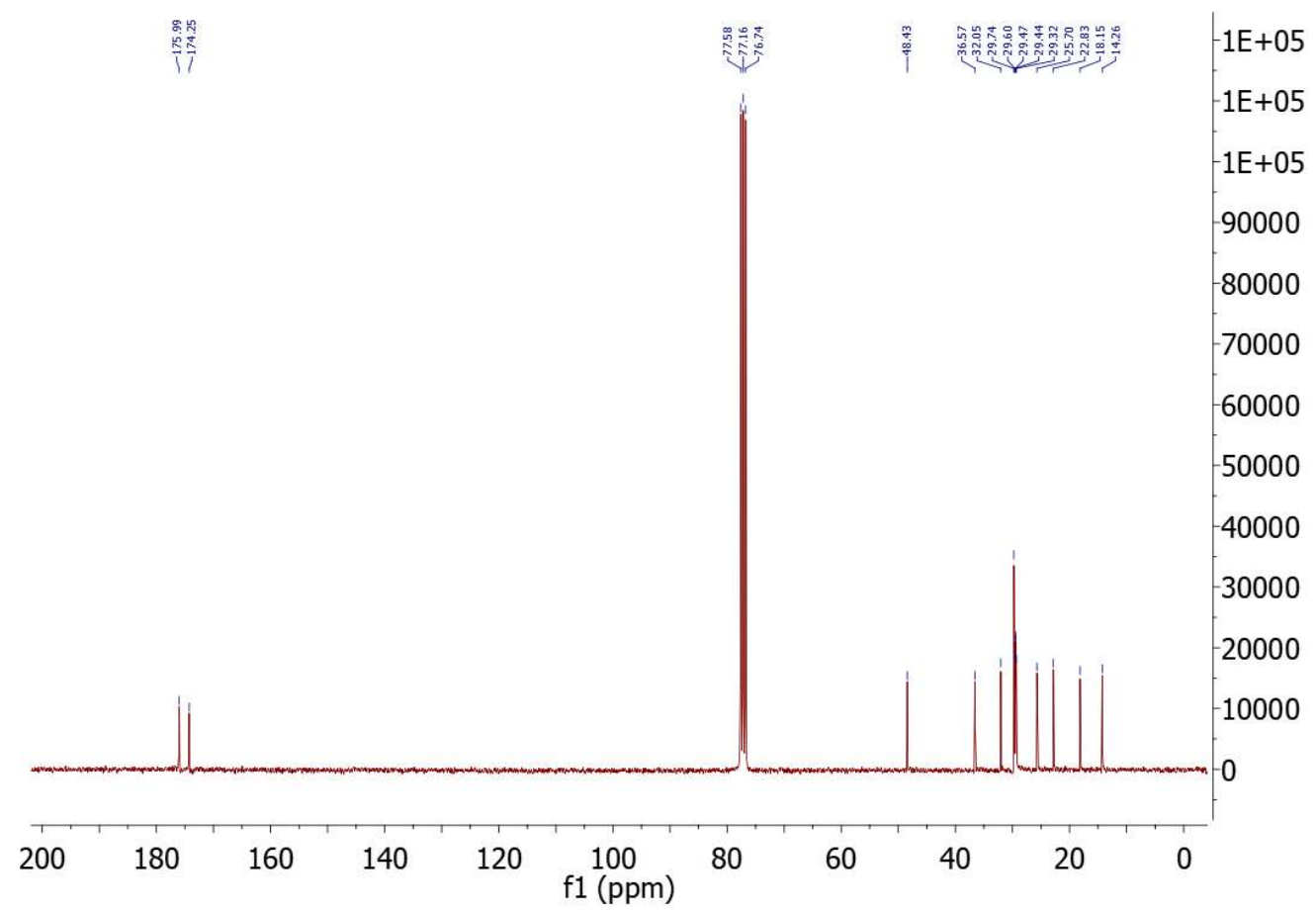

Figure $\mathbf{S 1 5} .{ }^{13} \mathrm{C}$ NMR spectrum $\left(100 \mathrm{MHz}, \mathrm{CDCl}_{3}\right)$ of compound $1 \mathrm{a}$. 


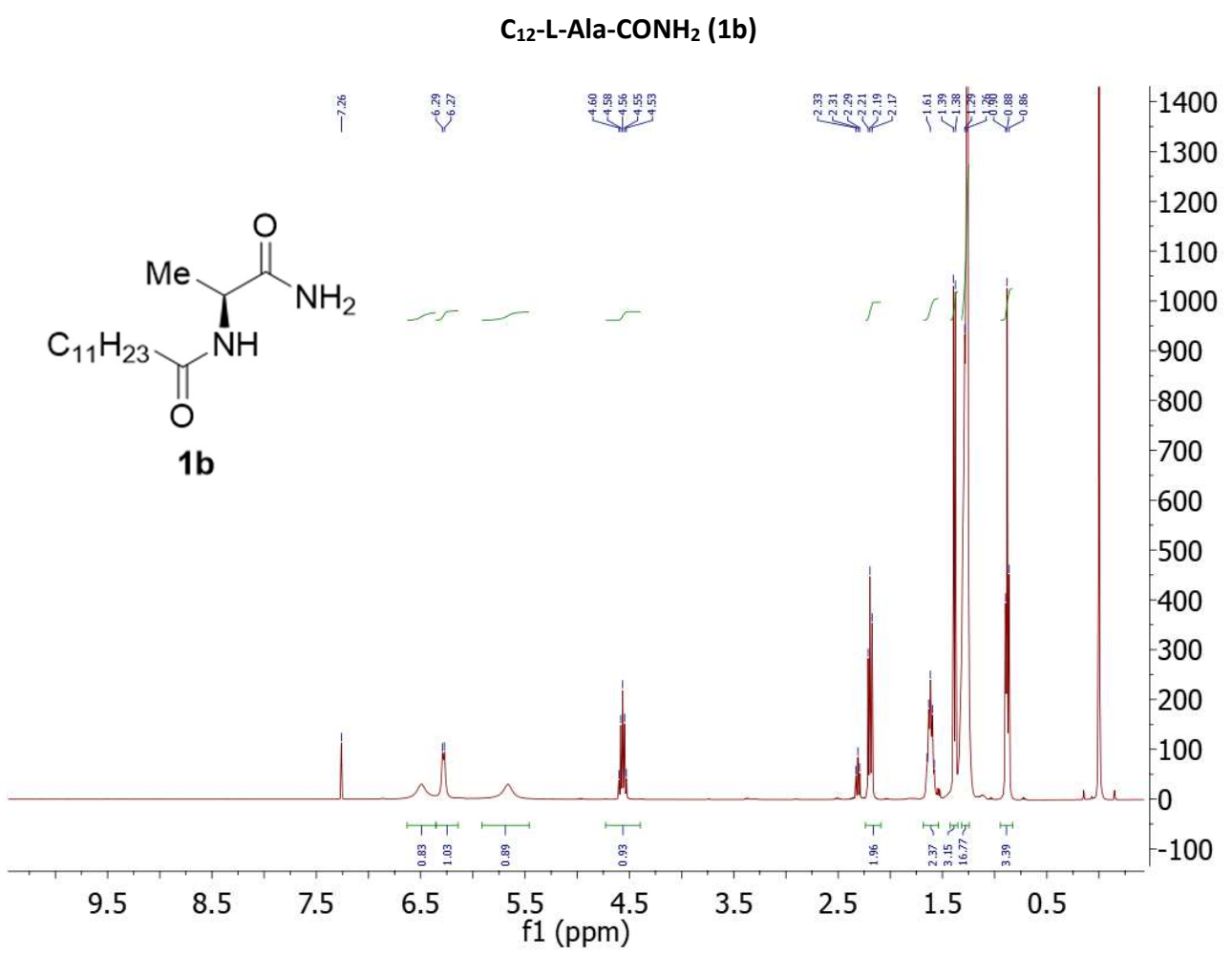

Figure S16. ${ }^{1} \mathrm{H}$ NMR spectrum (400 MHz, $\mathrm{CDCl}_{3}$ ) of compound $\mathbf{1 b}$.

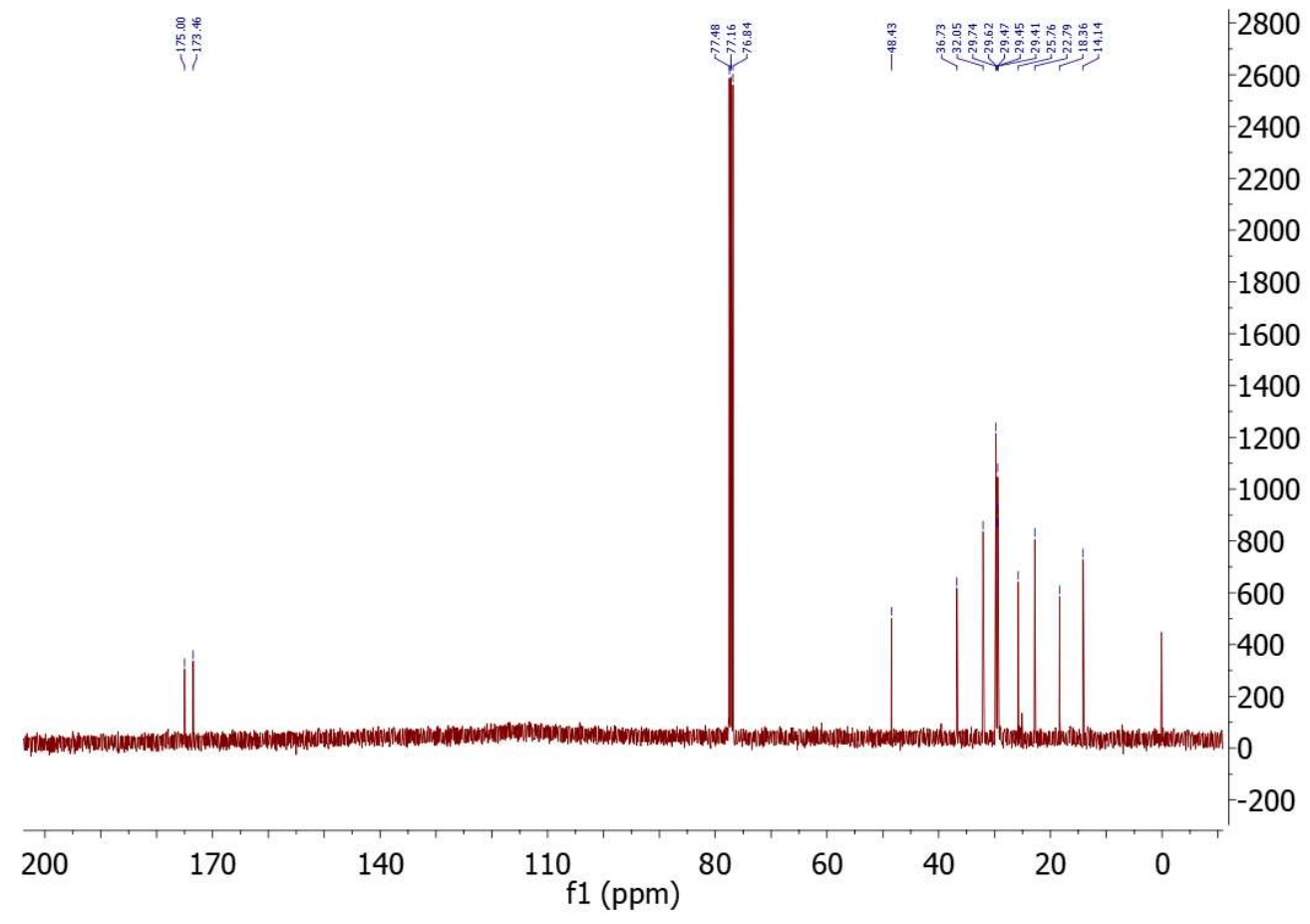

Figure S17. ${ }^{13} \mathrm{C}$ NMR spectrum (100 MHz, $\left.\mathrm{CDCl}_{3}\right)$ of compound $\mathbf{1 b}$. 


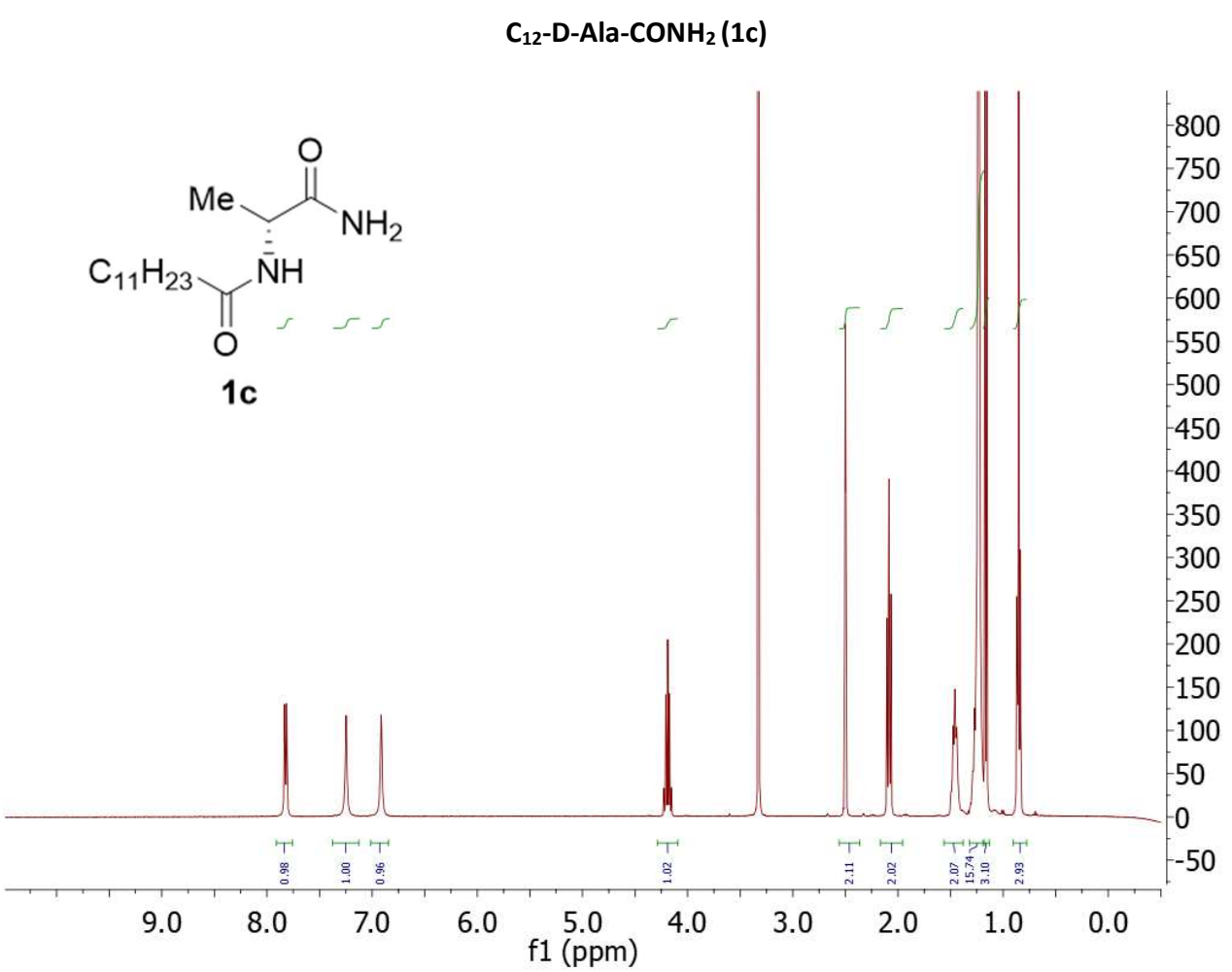

Figure S18. ${ }^{1} \mathrm{H}$ NMR spectrum (400 MHz, DMSO-d 6 ) of compound $1 \mathrm{c}$.

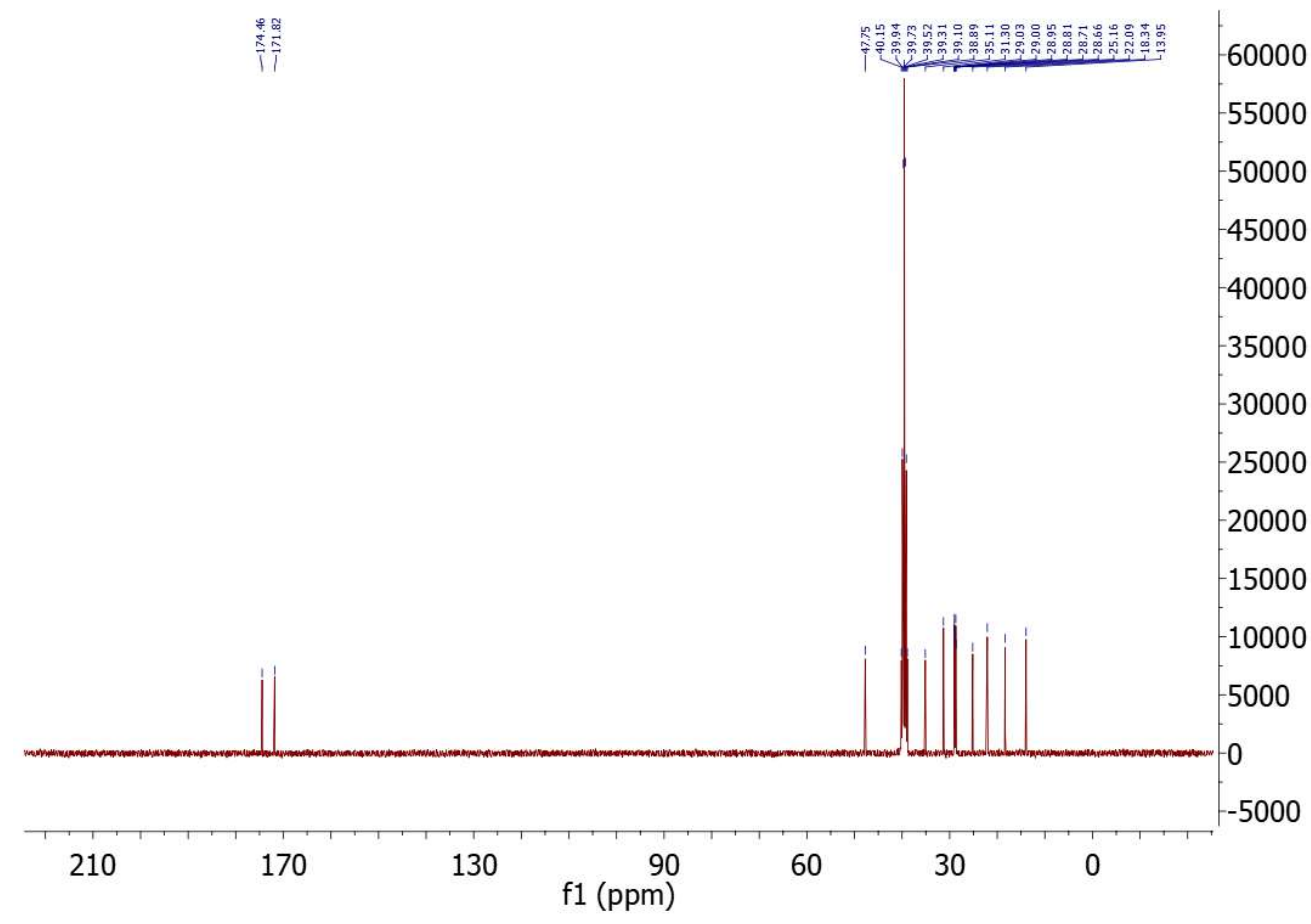

Figure $\mathbf{S 1 9} .{ }^{13} \mathrm{C}$ NMR spectrum (100 MHz, DMSO- $\mathrm{d}_{6}$ ) of compound $\mathbf{1 c}$. 


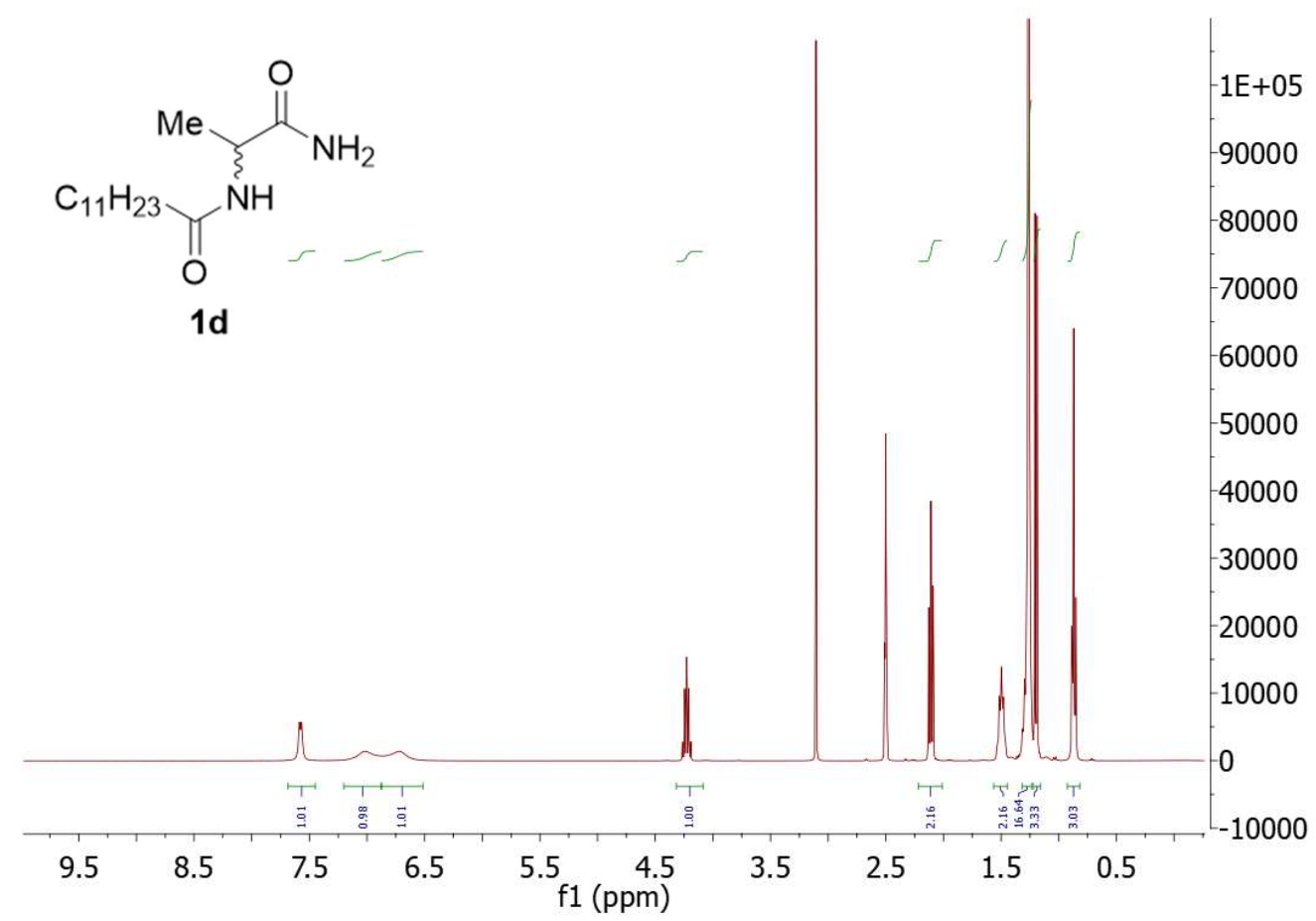

Figure S20. ${ }^{1} \mathrm{H}$ NMR spectrum (400 MHz, DMSO-d $_{6}$ ) of compound $\mathbf{1 d}$.

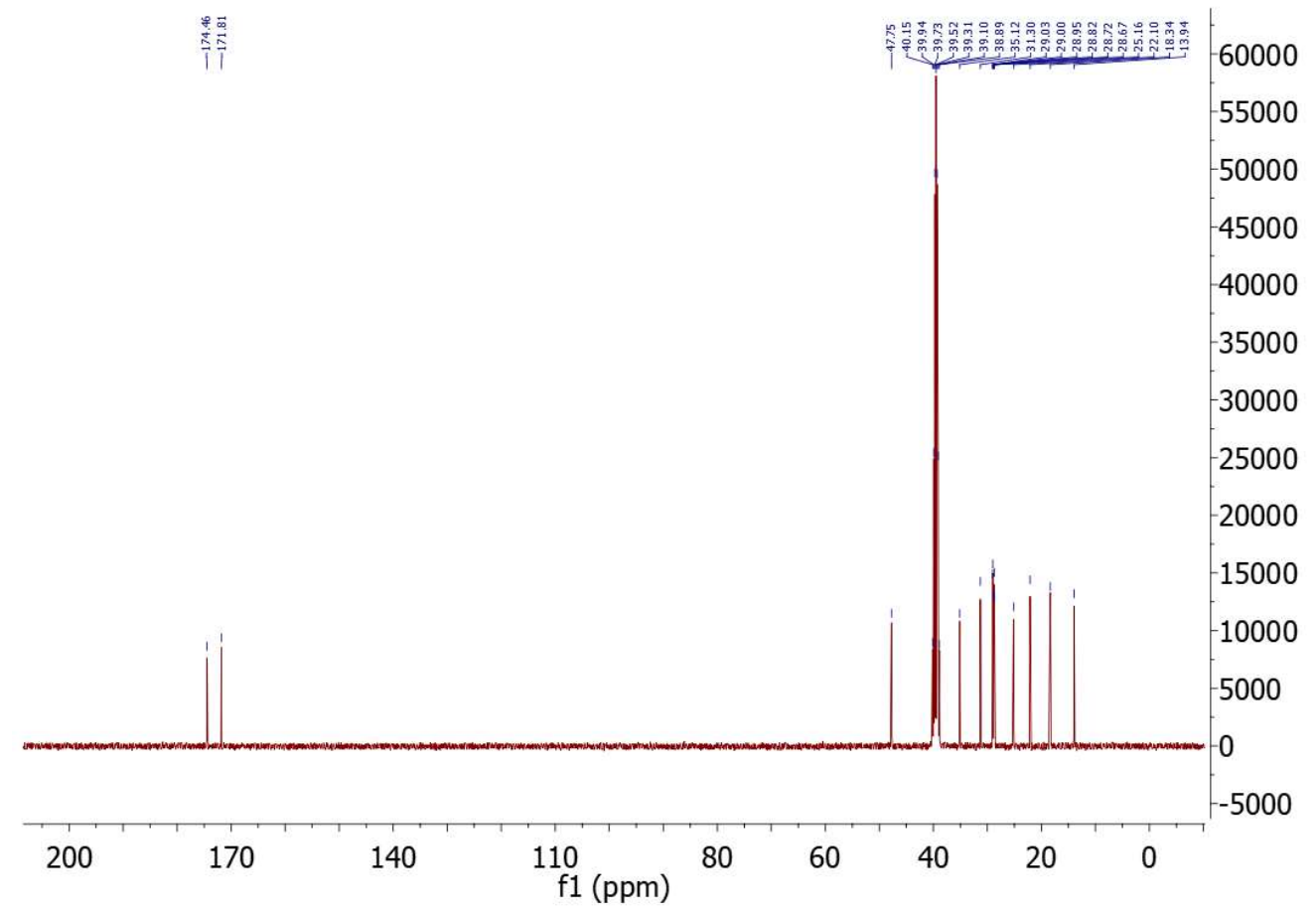

Figure S21. ${ }^{13} \mathrm{C}$ NMR spectrum (100 MHz, DMSO- $\mathrm{d}_{6}$ ) of compound $1 \mathbf{d}$. 


\section{$\mathrm{C}_{12}$-L-Val-COOH (2a)}

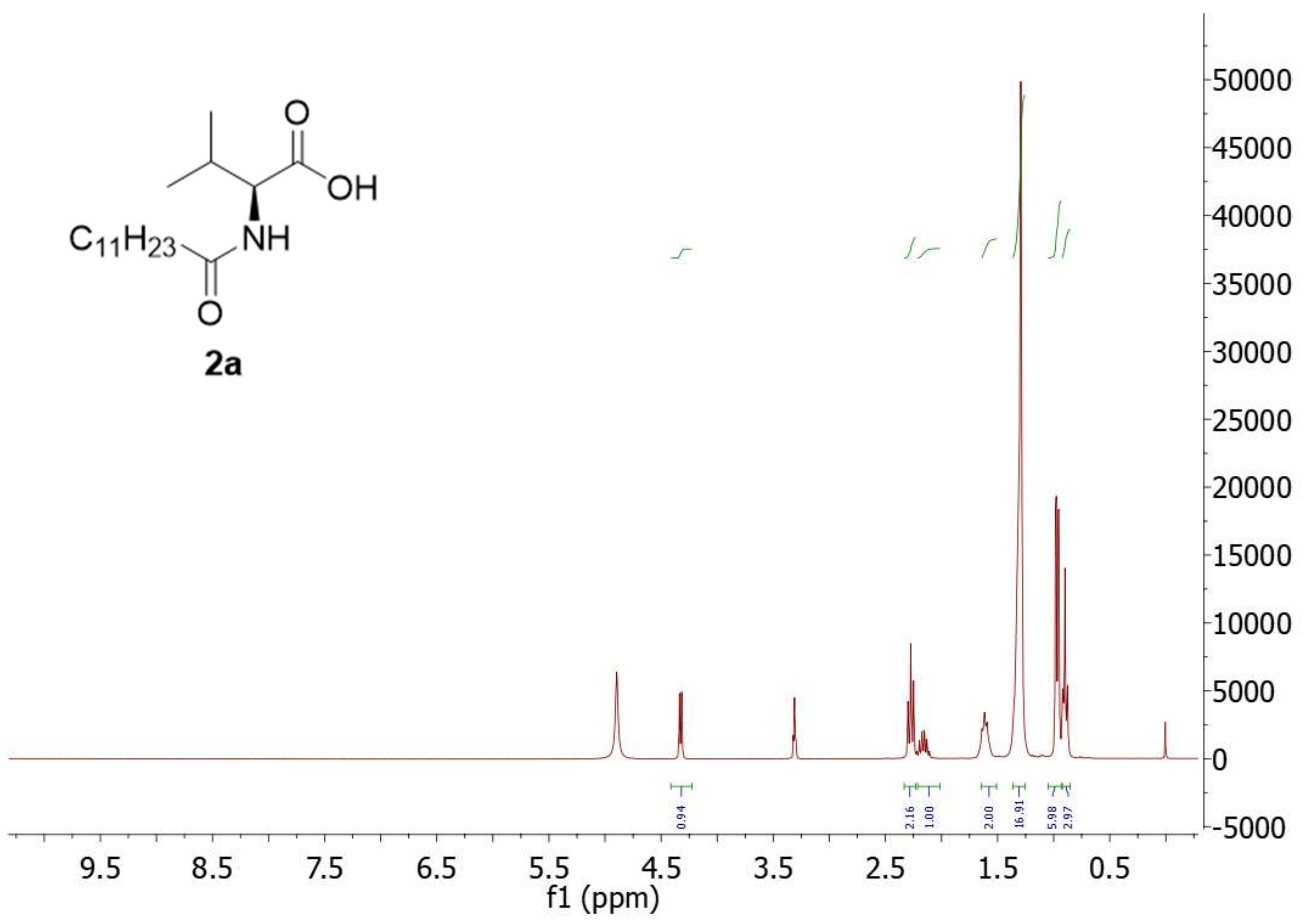

Figure S22. ${ }^{1} \mathrm{H}$ NMR spectrum $\left(400 \mathrm{MHz}, \mathrm{MeOH}-\mathrm{d}_{4}\right)$ of compound $2 \mathrm{a}$.

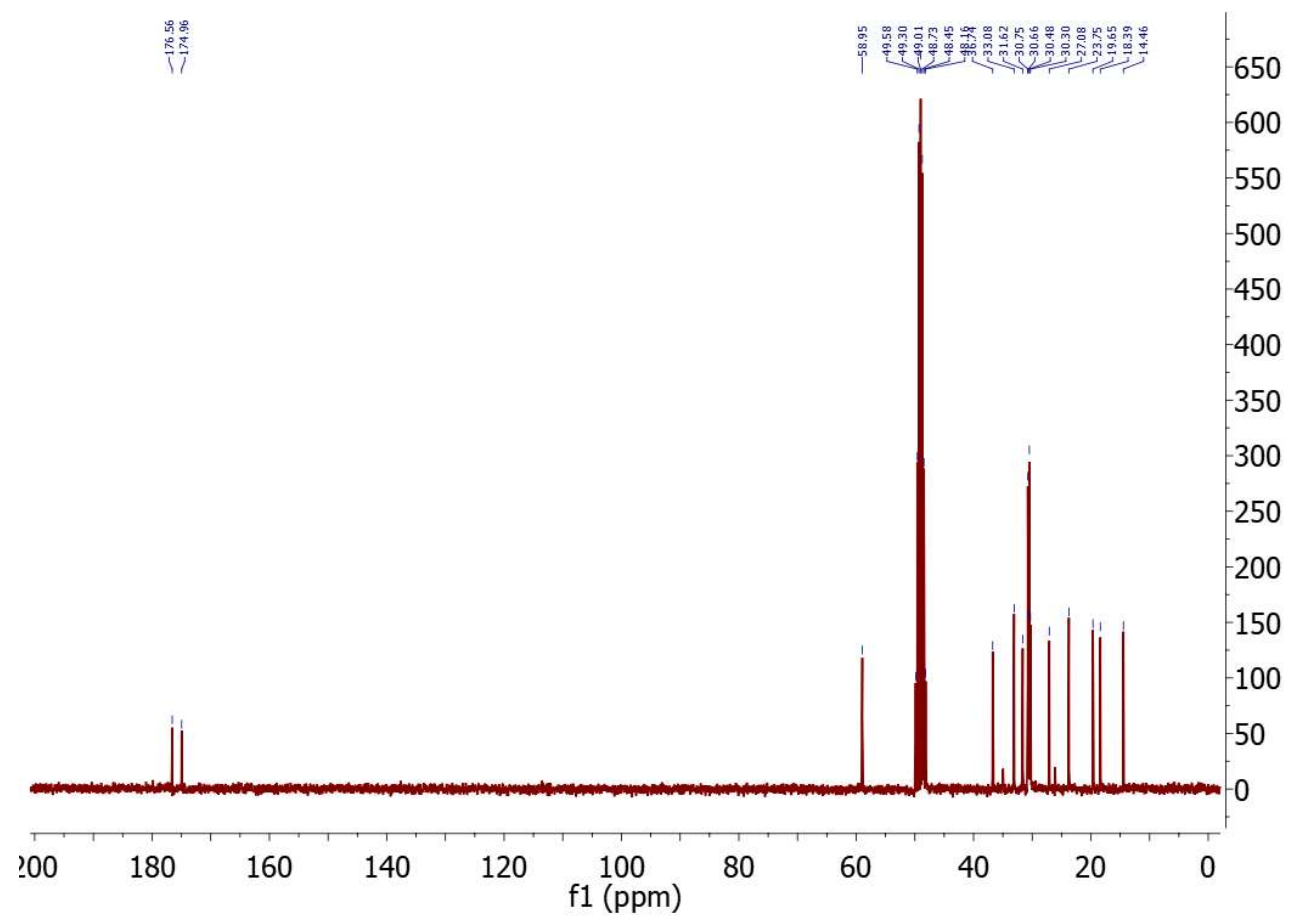

Figure S23. ${ }^{13} \mathrm{C}$ NMR spectrum (100 MHz, MeOH- $\mathrm{d}_{4}$ ) of compound 2a. 


\section{$\mathrm{C}_{12}$-L-Val-CONH 2 (2b)}

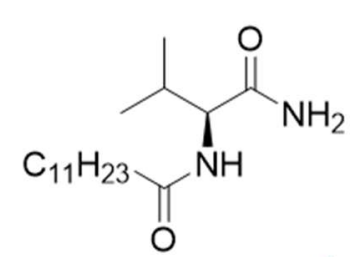

2b

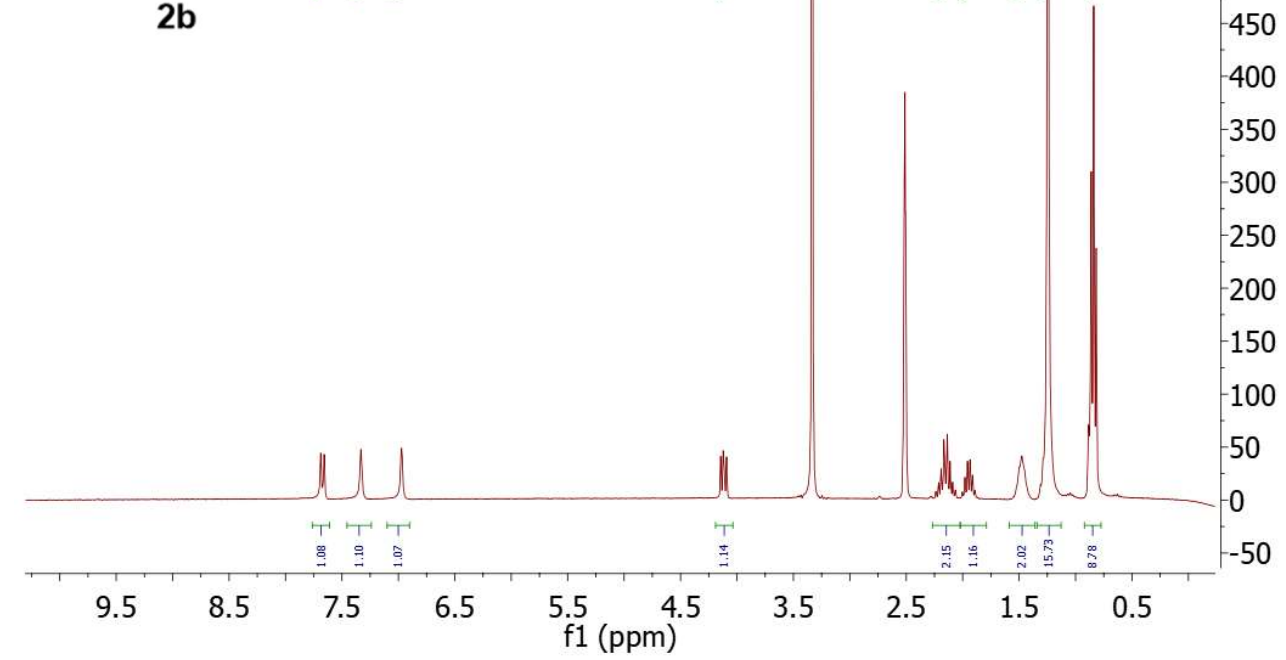

Figure S24. ${ }^{1} \mathrm{H}$ NMR spectrum (400 MHz, DMSO- $\mathrm{d}_{6}$ ) of compound $\mathbf{2 b}$.

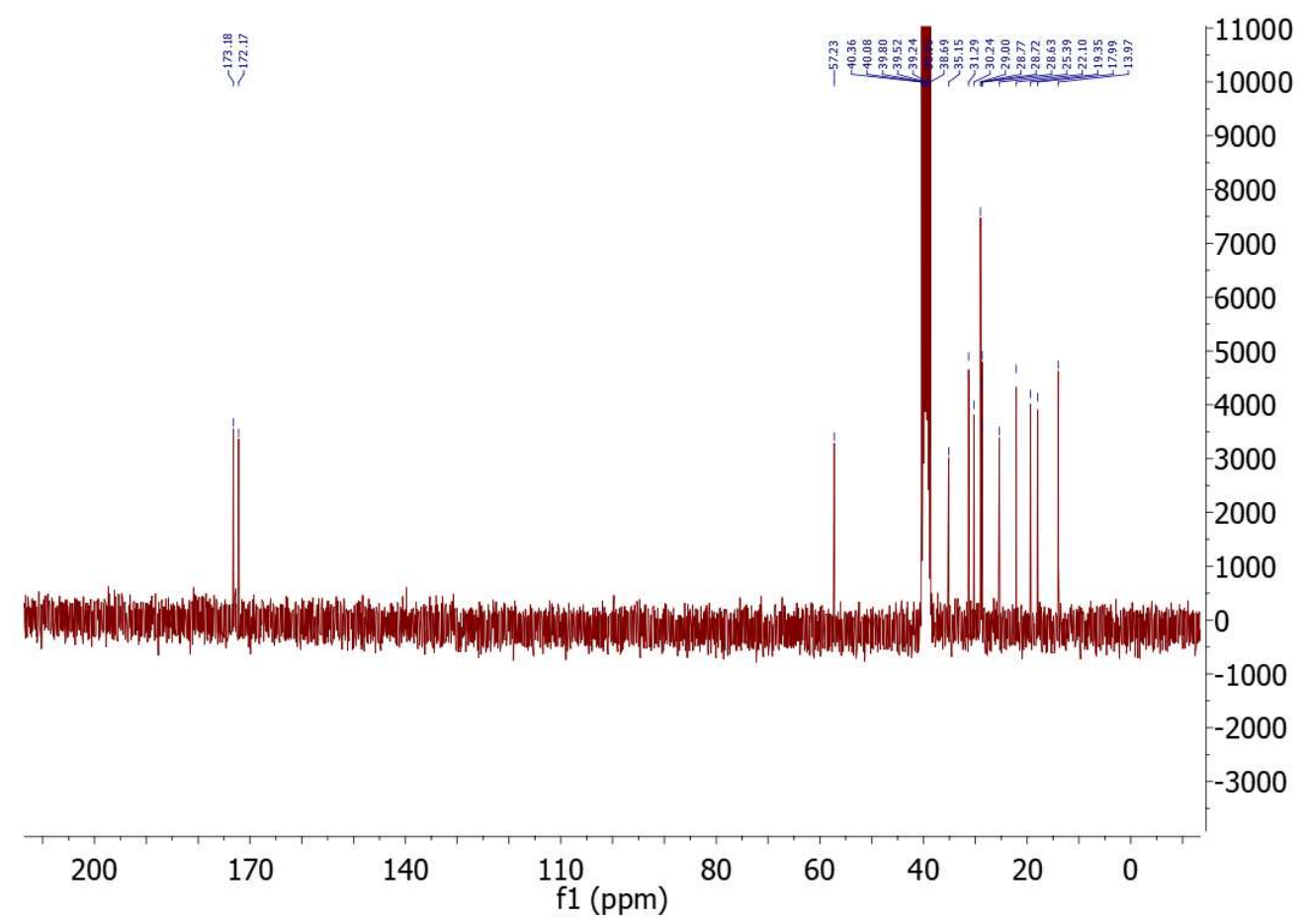

Figure S25. ${ }^{13} \mathrm{C}$ NMR spectrum (100 MHz, DMSO-d 6 ) of compound $\mathbf{2 b}$. 


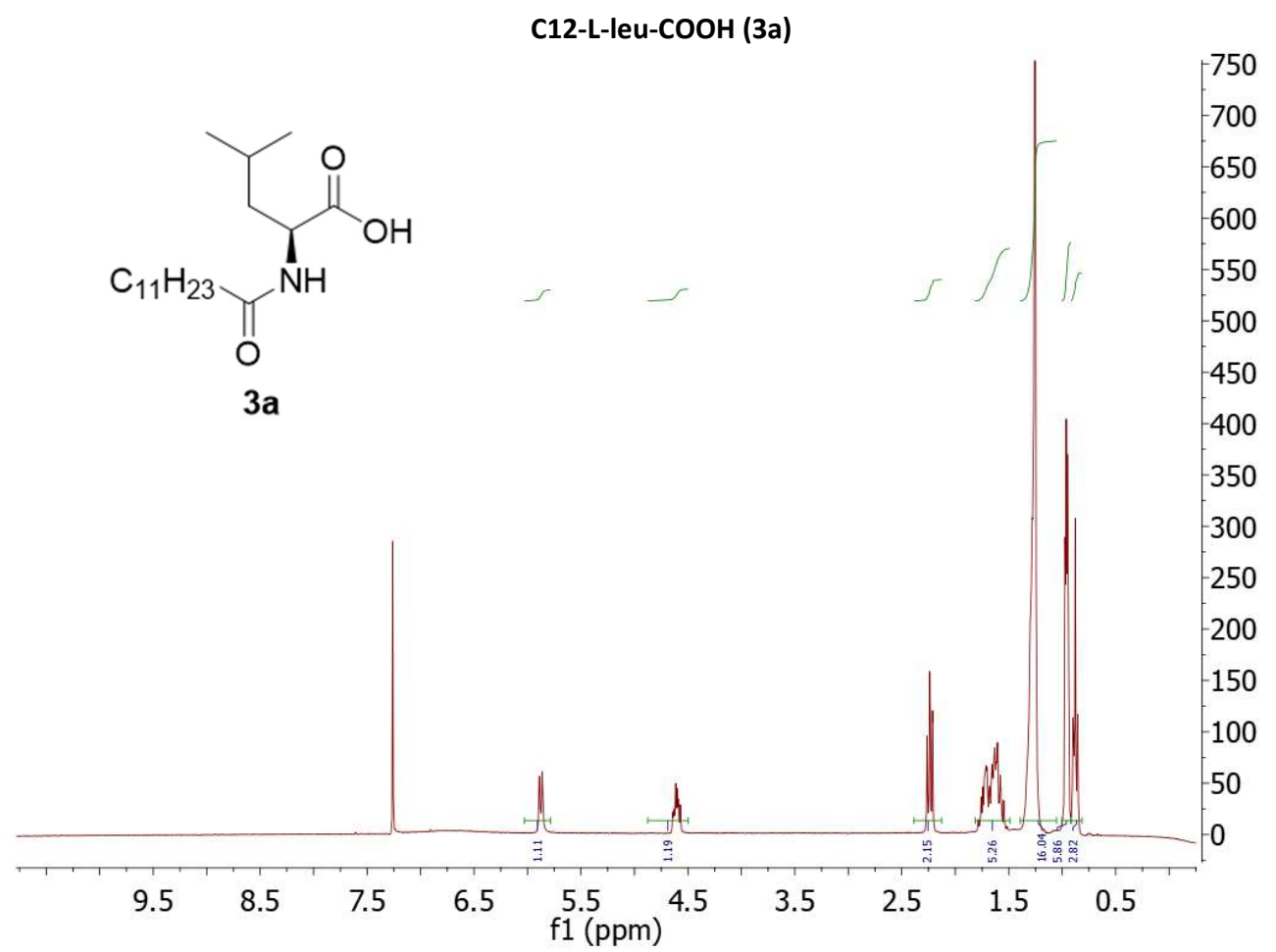

Figure S26. ${ }^{1 \mathrm{H}} \mathrm{NMR}$ spectrum $\left(400 \mathrm{MHz}, \mathrm{CDCl}_{3}\right.$ ) of compound 3 a.

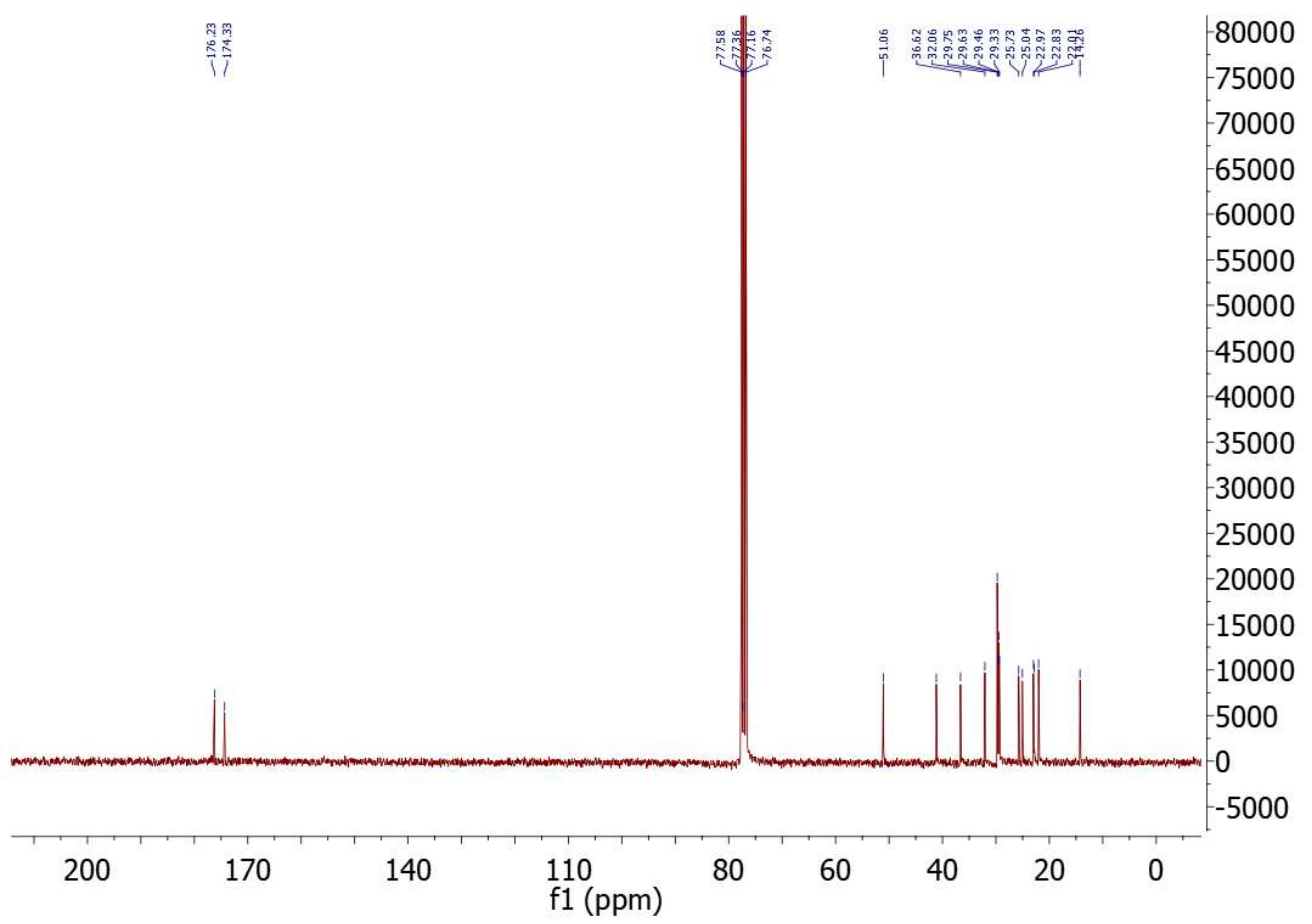

Figure S27. ${ }^{13} \mathrm{C}$ NMR spectrum (100 MHz, $\mathrm{CDCl}_{3}$ ) of compound $\mathbf{3 a}$. 


\section{C12-L-leu-CONH 2 (3b)}

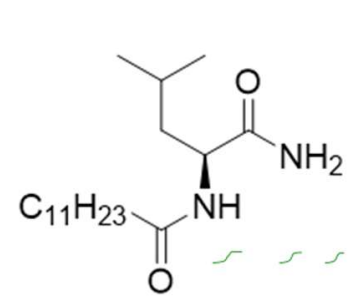

$3 b$

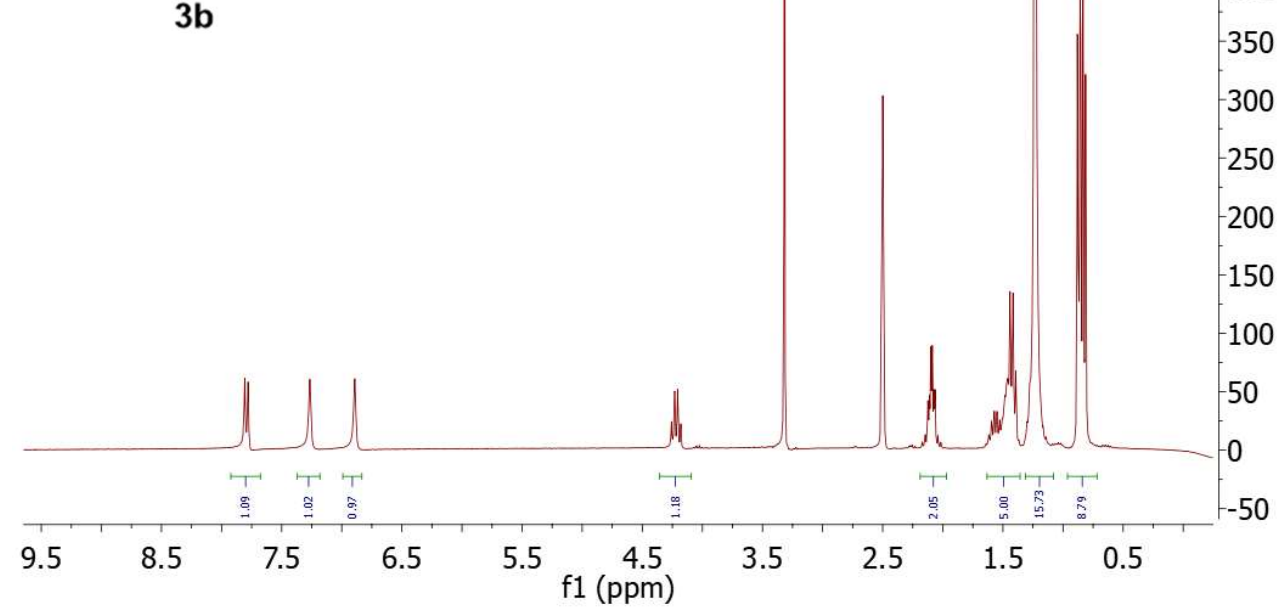

Figure S28. ${ }^{1} \mathrm{H}$ NMR spectrum (400 MHz, DMSO-d $\mathrm{d}_{6}$ ) of compound $\mathbf{3 b}$.

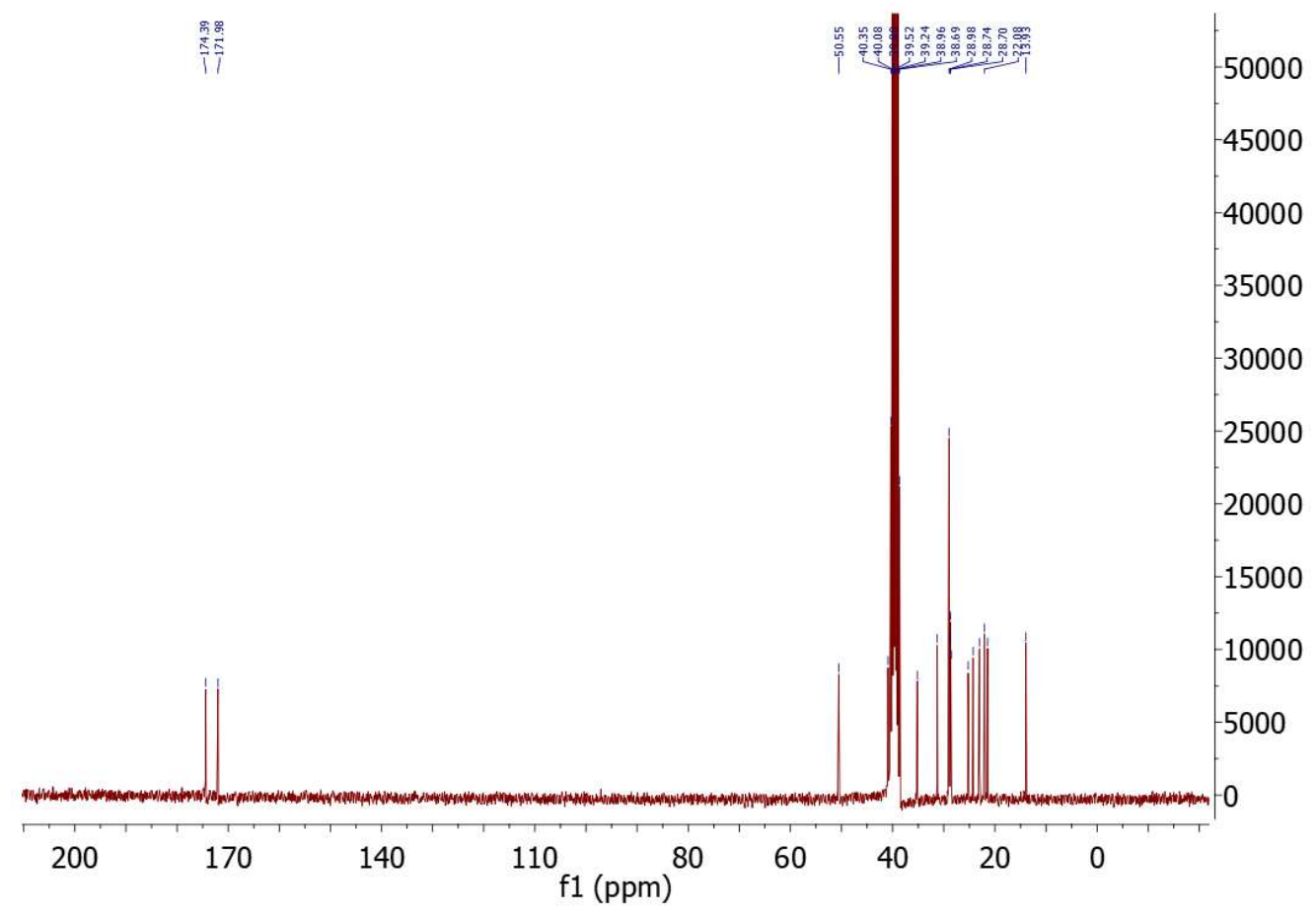

Figure $\mathbf{S 2 9} .{ }^{13} \mathrm{C}$ NMR spectrum (100 MHz, DMSO- $\mathrm{d}_{6}$ ) of compound $\mathbf{3 b}$. 


\section{$\mathrm{C}_{12}$-L-Phe-COOH (4a)}

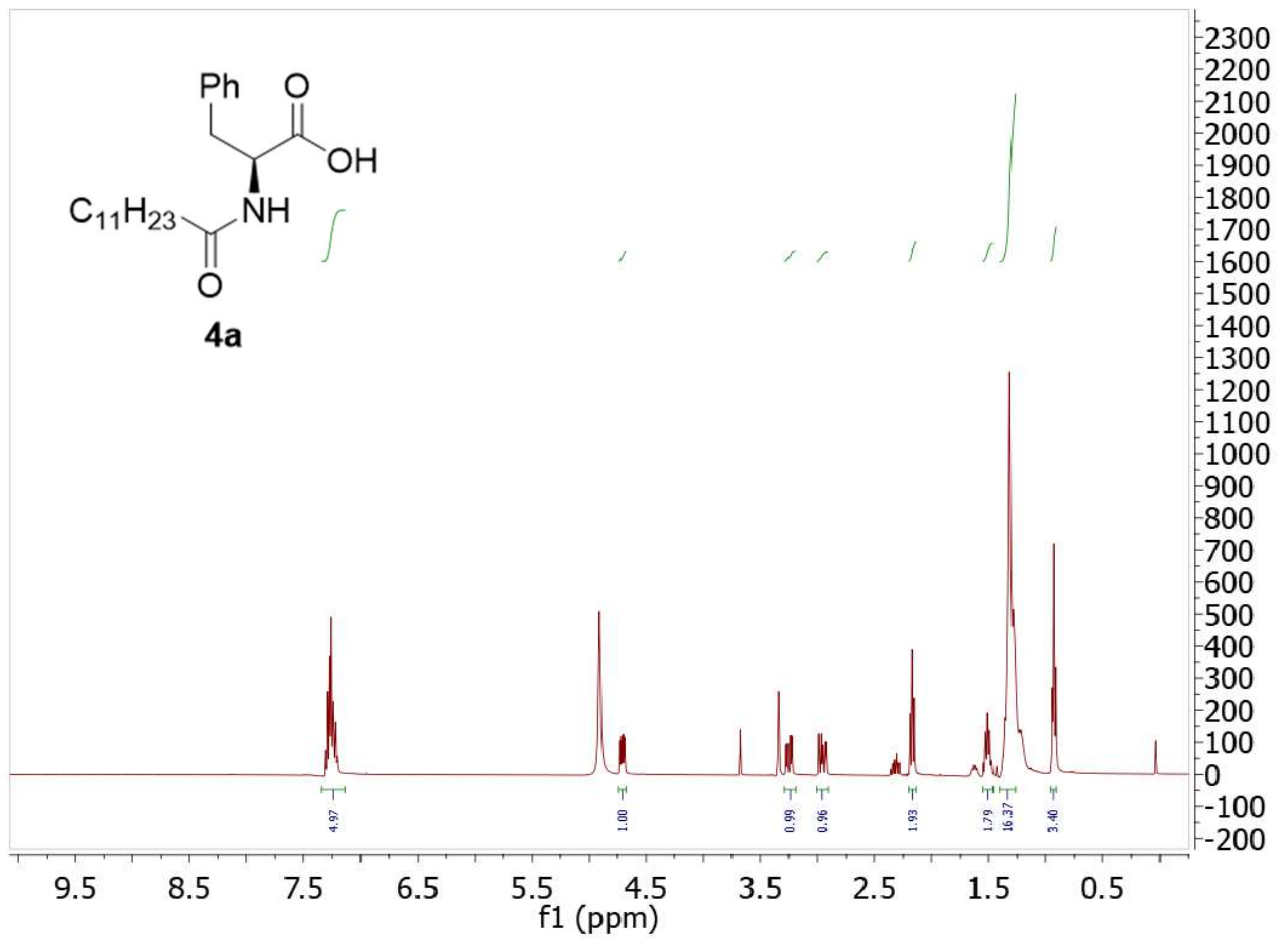

Figure S30. ${ }^{1} \mathrm{H}$ NMR spectrum $\left(400 \mathrm{MHz}, \mathrm{MeOH}-\mathrm{d}_{4}\right)$ of compound $4 \mathrm{a}$.

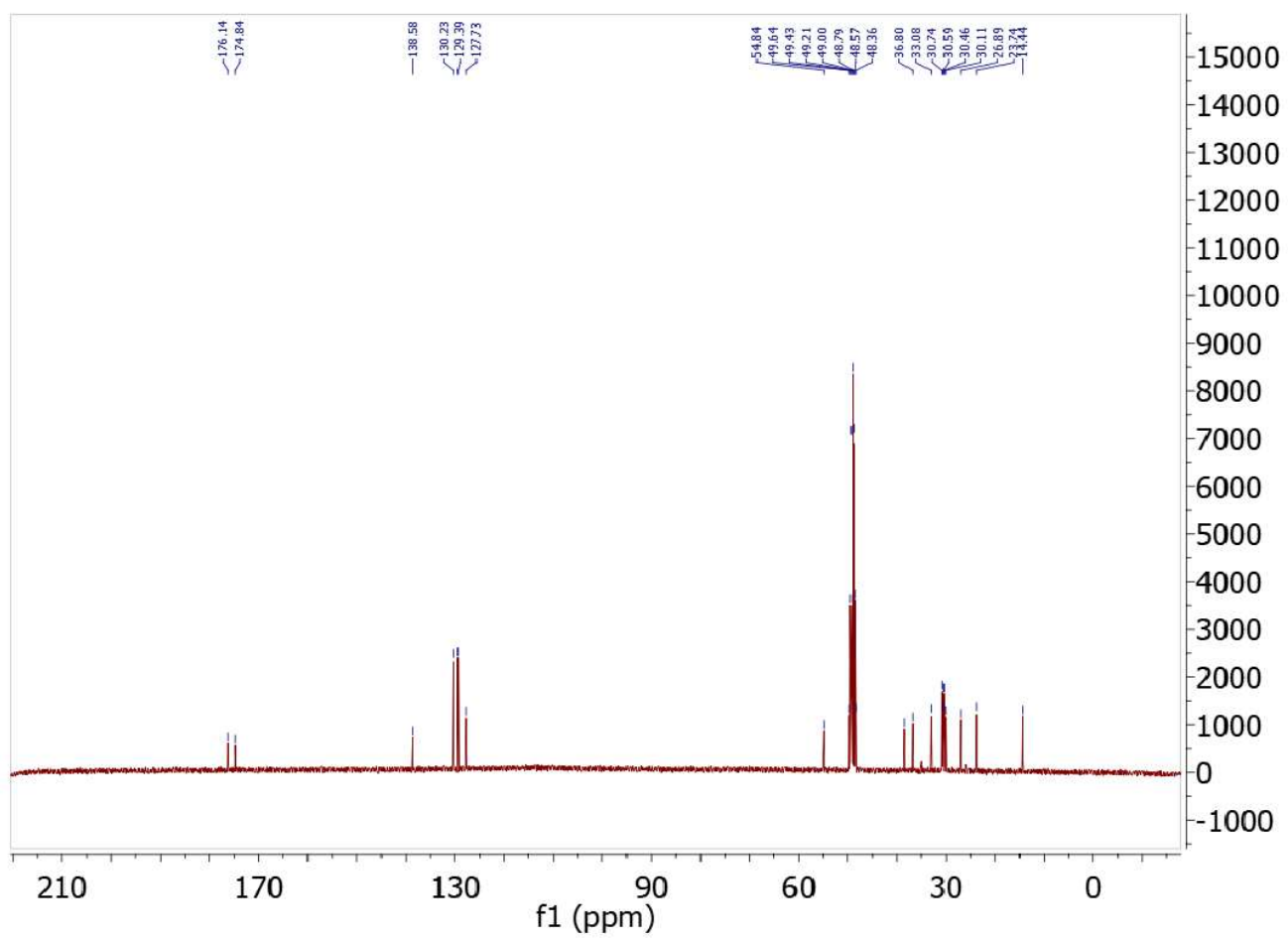

Figure S31. ${ }^{13} \mathrm{C}$ NMR spectrum (100 MHz, MeOH-d $\mathrm{d}_{4}$ ) of compound 4a. 


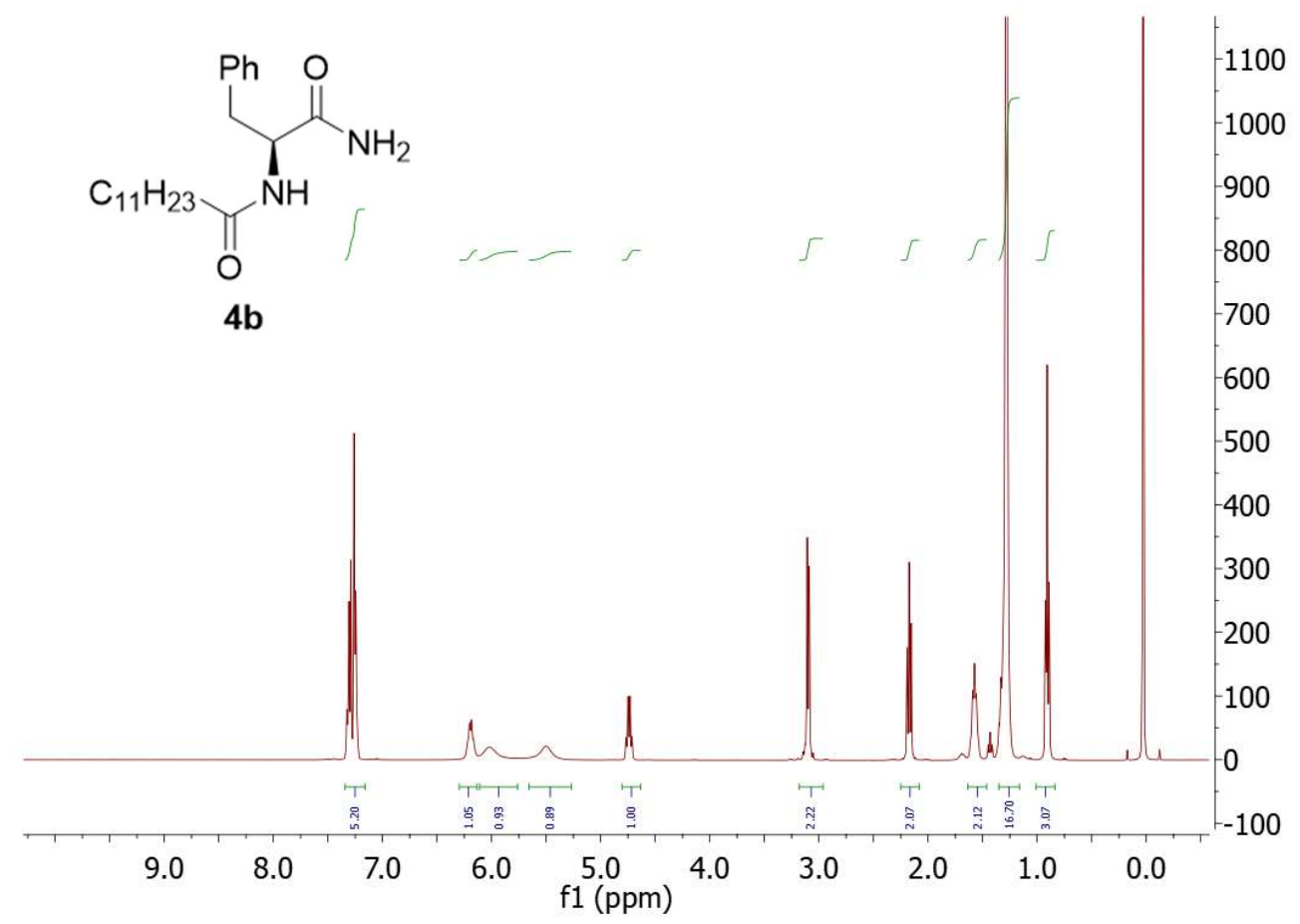

Figure S32. ${ }^{1} \mathrm{H}$ NMR spectrum $\left(400 \mathrm{MHz}, \mathrm{CDCl}_{3}\right.$ ) of compound $\mathbf{4 b}$.

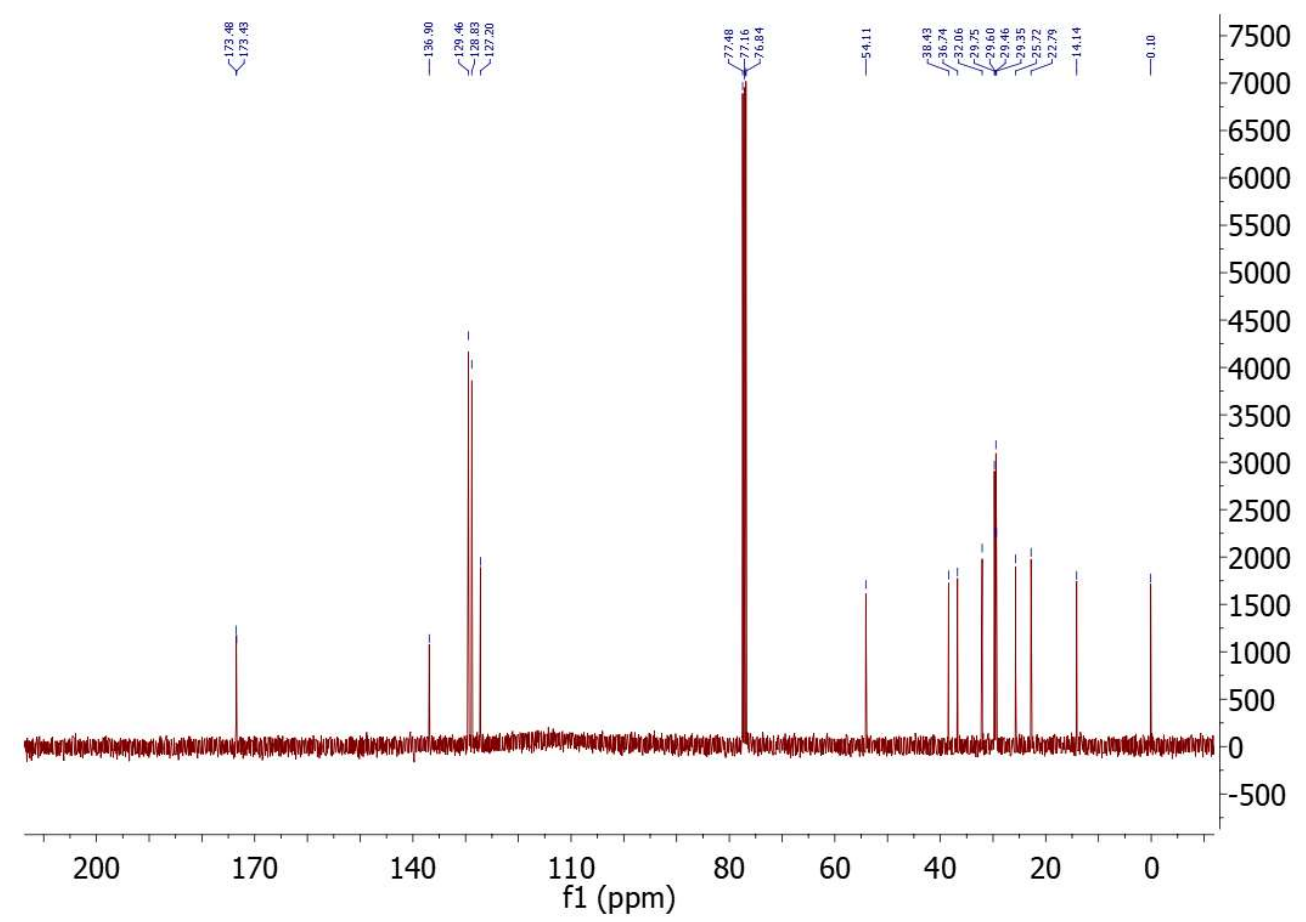

Figure S33. ${ }^{13} \mathrm{C}$ NMR spectrum (100 MHz, $\left.\mathrm{CDCl}_{3}\right)$ of compound $\mathbf{4 b}$. 
Single Crystal X-ray Diffraction: Pi-stacking evaluation of compounds $4 \mathrm{a}$ and $4 \mathrm{~b}$

Compound 1a

Least square plane on ring C9-14 was calculated.

The centroid-centroid distance between two C9-C14 rings is 5.32290(4) $\AA$

The vertical distance (least square plane to centroid), 3.485(12) $\AA$

The slippage between the two rings is 4.023(10) $\AA$.

The angle between the two least square planes is 0 .

\section{Compound $\mathbf{1 b}$}

Least square plane on ring C9-14 was calculated.

The centroid-centroid distance between two C9-C14 rings is 4.949 (3) $\AA$

The vertical distance (least square plane to centroid), 3.060(4) $\AA$

The slippage between the two rings is 3.890(5) A.

The angle between the two least square planes is 0 .

Conclusion: In both cases, the slippage between the two rings is too big (and so is the centroid-to centroid distance) to state that there is a pi-pi stacking interaction (even if the vertical plane-to-centroid distance is in the range of what we would expect for a pi-pi stacking interaction, the offset of the two rings is too big). This is probably more a $\mathrm{C}-\mathrm{H}---$ pi interaction driven by pi-sigma attraction, as only the edges of the rings overlay. ${ }^{8}$ 


\section{Single Crystal X-ray Diffraction}

A colorless crystal of 4 a (approximate dimensions $0.65 \times 0.40 \times 0.36 \mathrm{~mm}^{3}$ ) was placed on a Bruker Apex X8 diffractometer equipped with an Apex II CCD detector at $100 \mathrm{~K}$.

Data collection

The data collection was carried out using Mo K $\alpha$ radiation ( $\lambda=0.71073 \AA$, graphite monochromator) with a frame time of 15 seconds and a detector distance of $40 \mathrm{~mm}$. A collection strategy was calculated and complete data to a resolution of $0.77 \AA \AA$ with a redundancy of 2.5 were collected. Data to a resolution of $0.77 \AA$ were considered in the reduction. Final cell constants were calculated from the xyz centroids of 1201 strong reflections from the actual data collection after integration (SAINT). ${ }^{9}$ The intensity data were corrected for absorption (SADABS). ${ }^{10}$ Please refer to Table 1 for additional crystal and refinement information.

Structure solution and refinement

The space group $\mathrm{P} 2{ }_{1} 2_{1} 2_{1}$ was determined based on intensity statistics and systematic absences. The structure was solved using Superflip ${ }^{11}$ and refined using full-matrix least-squares on $\mathrm{F}^{2}$ within the CRYSTALS suite. ${ }^{12} \mathrm{~A}$ charge-flipping solution was calculated, which provided most non-hydrogen atoms from the E-map. Full-matrix least squares / difference Fourier cycles were performed, which located the remaining non-hydrogen atoms. All non-hydrogen atoms were refined with anisotropic displacement parameters. Hydrogen atoms were initially refined with restraints on bond lengths and angles, after which the positions were used as the basis for a riding model. ${ }^{13}$ The final full matrix least squares refinement converged to $R 1=0.1091$ and $w R 2=0.2706$ $\left(F^{2}\right.$, all data). The goodness-of-fit was 1.0258 . On the basis of the final model, the calculated density was $1.174 \mathrm{~g} / \mathrm{cm}^{3}$ and $F(000)$, $760 \mathrm{e}^{-}$.

The crystal structures of $\mathbf{4 a}$ (C12-L-phe-COOH) and $\mathbf{4 b}$ (C12-L-phe-CONH2) have been submitted to the joint CCDC/FIZ Karlsruhe deposition service. The CCDC or CSD numbers are 1959468 for $\mathbf{4 a}$ and 1959469 for $\mathbf{4 b .}$ 
Table S3. Crystal data and structure refinement for compound 4a.

\begin{tabular}{|c|c|c|}
\hline Empirical formula & \multicolumn{2}{|l|}{$\mathrm{C} 21 \mathrm{H} 33 \mathrm{~N} 1 \mathrm{O} 3$} \\
\hline Formula weight & \multicolumn{2}{|l|}{347.50} \\
\hline Crystal color, shape, size & \multicolumn{2}{|c|}{ colorless plate, $0.65 \times 0.40 \times 0.36 \mathrm{~mm}^{3}$} \\
\hline Temperature & \multicolumn{2}{|l|}{$100 \mathrm{~K}$} \\
\hline Wavelength & \multicolumn{2}{|l|}{$0.71073 \AA$} \\
\hline Crystal system, space group & \multicolumn{2}{|c|}{ Orthorhombic, $\mathrm{P} 2{ }_{1} 2{ }_{1} 2_{1}$} \\
\hline \multirow[t]{3}{*}{ Unit cell dimensions } & $a=12.762(4) \AA$ & $\alpha=90^{\circ}$ \\
\hline & $\mathrm{b}=28.938(8) \AA$ & $\beta=90^{\circ}$. \\
\hline & $c=5.3229(15) \AA$ & $\gamma=90^{\circ}$. \\
\hline Volume & \multicolumn{2}{|l|}{$1965.8(10) \AA^{3}$} \\
\hline Z & \multicolumn{2}{|l|}{4} \\
\hline Density (calculated) & \multicolumn{2}{|l|}{$1.174 \mathrm{~g} / \mathrm{cm}^{3}$} \\
\hline Absorption coefficient & \multicolumn{2}{|l|}{$0.077 \mathrm{~mm}^{-1}$} \\
\hline$F(000)$ & \multicolumn{2}{|l|}{760} \\
\hline
\end{tabular}

\section{Data collection}

Diffractometer

Theta range for data collection

Index ranges

Reflections collected

Independent reflections

Observed Reflections

Completeness to theta $=26.097^{\circ}$

Kappa Apex II Duo, Bruker

1.744 to $27.763^{\circ}$.

$-16<=\mathrm{h}<=16,-37<=\mathrm{k}<=37,-4<=\mid<=6$

9333

2644 [Rint $=0.076]$

2203

$99.1 \%$

\section{Solution and Refinement}

Absorption correction

Semi-empirical from equivalents

Max. and min. transmission

1.00 and 0.56

Solution

Refinement method

Intrinsic methods

Full-matrix least-squares on $\mathrm{F}^{2}$

Weighting scheme

Chebychev polynomial (Watkin 1994, Prince 1982)

Data / restraints / parameters

2631 / 0 / 220

Goodness-of-fit on $\mathrm{F}^{2}$

1.0258

Final $R$ indices $[1>2 \sigma(I)]$

$\mathrm{R} 1=0.1091, w R 2=0.2683$

$R$ indices (all data)

$\mathrm{R} 1=0.1191, w R 2=0.2706$

Largest diff. peak and hole 
Table S4. Atomic coordinates $\left(\times 10^{4}\right)$ and equivalent isotropic displacement parameters $\left(\AA^{2} \times 10^{3}\right)$ for 4 a. $U\left(\right.$ eq) is defined as one third of the trace of the orthogonalized $U^{i j}$ tensor.

\begin{tabular}{|c|c|c|c|c|}
\hline & $x$ & $y$ & $z$ & $\mathrm{U}(\mathrm{eq}$ \\
\hline 01 & $5800(4)$ & $7381(2)$ & $4708(10)$ & 23 \\
\hline $\mathrm{C} 2$ & $6278(5)$ & $7404(2)$ & $2660(13)$ & 17 \\
\hline N3 & $7010(4)$ & $7727(2)$ & $2302(11)$ & 18 \\
\hline $\mathrm{C} 4$ & $7227(5)$ & $8073(2)$ & $4178(13)$ & 15 \\
\hline $\mathrm{C} 5$ & $8262(5)$ & $7956(2)$ & $5491(12)$ & 16 \\
\hline 06 & $9049(4)$ & $7982(2)$ & $3990(9)$ & 21 \\
\hline 07 & $8300(4)$ & $7849(2)$ & $7676(9)$ & 26 \\
\hline $\mathrm{C} 8$ & $7282(5)$ & $8558(2)$ & 2995(13) & 20 \\
\hline $\mathrm{C} 9$ & $7483(5)$ & $8931(2)$ & $4896(14)$ & 17 \\
\hline C10 & $6664(6)$ & $9078(2)$ & $6492(15)$ & 26 \\
\hline $\mathrm{C} 11$ & $6859(7)$ & $9412(2)$ & $8296(15)$ & 28 \\
\hline $\mathrm{C} 12$ & $7856(7)$ & $9602(2)$ & $8537(16)$ & 30 \\
\hline C13 & $8641(6)$ & $9460(2)$ & 6992(15) & 29 \\
\hline C14 & $8472(5)$ & $9123(2)$ & $5161(14)$ & 21 \\
\hline C15 & $6082(5)$ & $7059(2)$ & $658(14)$ & 20 \\
\hline C16 & $6321(6)$ & $6563(2)$ & $1472(13)$ & 20 \\
\hline C17 & $5983(6)$ & $6214(2)$ & $-500(13)$ & 22 \\
\hline C18 & $6320(6)$ & $5720(2)$ & $60(14)$ & 21 \\
\hline C19 & $5913(6)$ & $5374(2)$ & $-1827(12)$ & 21 \\
\hline $\mathrm{C} 20$ & $6291(6)$ & $4881(2)$ & $-1498(13)$ & 20 \\
\hline $\mathrm{C} 21$ & $5890(6)$ & $4634(2)$ & $858(14)$ & 24 \\
\hline $\mathrm{C} 22$ & $6194(5)$ & $4130(2)$ & $922(12)$ & 18 \\
\hline $\mathrm{C} 23$ & $5806(5)$ & $3870(2)$ & $3210(14)$ & 21 \\
\hline $\mathrm{C} 24$ & $5930(6)$ & $3349(2)$ & $3114(15)$ & 23 \\
\hline $\mathrm{C} 25$ & $5629(7)$ & $3106(2)$ & $5513(14)$ & 28 \\
\hline
\end{tabular}


Table S5. Bond lengths $[\AA ̊]$ and angles $\left[^{\circ}\right]$ for compound 4 a.

\begin{tabular}{|c|c|c|c|}
\hline O1-C2 & $1.251(9)$ & $\mathrm{C} 2-\mathrm{N} 3$ & $1.336(8)$ \\
\hline C2-C15 & $1.482(9)$ & N3-C4 & $1.442(8)$ \\
\hline N3-H31 & 0.852 & $\mathrm{C} 4-\mathrm{C} 5$ & $1.532(9)$ \\
\hline $\mathrm{C} 4-\mathrm{C} 8$ & $1.538(9)$ & $\mathrm{C} 4-\mathrm{H} 41$ & 0.978 \\
\hline C5-O6 & $1.285(8)$ & $\mathrm{C} 5-07$ & $1.205(8)$ \\
\hline O6-H61 & 0.828 & $\mathrm{C} 8-\mathrm{C} 9$ & $1.502(9)$ \\
\hline $\mathrm{C} 8-\mathrm{H} 81$ & 0.974 & $\mathrm{C} 8-\mathrm{H} 82$ & 0.970 \\
\hline C9-C10 & $1.413(10)$ & C9-C14 & $1.386(9)$ \\
\hline C10-C11 & $1.385(10)$ & $\mathrm{C} 10-\mathrm{H} 101$ & 0.943 \\
\hline C11-C12 & $1.393(12)$ & $\mathrm{C} 11-\mathrm{H} 111$ & 0.930 \\
\hline C12-C13 & $1.360(12)$ & $\mathrm{C} 12-\mathrm{H} 121$ & 0.928 \\
\hline C13-C14 & $1.397(10)$ & $\mathrm{C} 13-\mathrm{H} 131$ & 0.942 \\
\hline C14-H141 & 0.930 & C15-C16 & $1.529(8)$ \\
\hline $\mathrm{C} 15-\mathrm{H} 151$ & 0.975 & $\mathrm{C} 15-\mathrm{H} 152$ & 0.989 \\
\hline C16-C17 & $1.519(9)$ & $\mathrm{C} 16-\mathrm{H} 161$ & 0.990 \\
\hline $\mathrm{C} 16-\mathrm{H} 162$ & 0.971 & C17-C18 & $1.523(9)$ \\
\hline C17-H171 & 0.971 & $\mathrm{C} 17-\mathrm{H} 172$ & 0.987 \\
\hline C18-C19 & $1.511(9)$ & $\mathrm{C} 18-\mathrm{H} 181$ & 0.986 \\
\hline $\mathrm{C} 18-\mathrm{H} 182$ & 0.969 & C19-C20 & $1.516(9)$ \\
\hline C19-H191 & 0.973 & C19-H192 & 0.989 \\
\hline C20-C21 & $1.531(10)$ & $\mathrm{C} 20-\mathrm{H} 201$ & 0.984 \\
\hline $\mathrm{C} 20-\mathrm{H} 2 \mathrm{O} 2$ & 0.966 & $\mathrm{C} 21-\mathrm{C} 22$ & $1.509(9)$ \\
\hline $\mathrm{C} 21-\mathrm{H} 211$ & 0.977 & $\mathrm{C} 21-\mathrm{H} 212$ & 0.980 \\
\hline $\mathrm{C} 22-\mathrm{C} 23$ & $1.514(9)$ & $\mathrm{C} 22-\mathrm{H} 221$ & 0.985 \\
\hline $\mathrm{C} 22-\mathrm{H} 222$ & 0.967 & C23-C24 & $1.518(9)$ \\
\hline $\mathrm{C} 23-\mathrm{H} 231$ & 0.972 & $\mathrm{C} 23-\mathrm{H} 232$ & 0.975 \\
\hline $\mathrm{C} 24-\mathrm{C} 25$ & $1.507(10)$ & $\mathrm{C} 24-\mathrm{H} 241$ & 0.988 \\
\hline $\mathrm{C} 24-\mathrm{H} 242$ & 0.974 & $\mathrm{C} 25-\mathrm{H} 253$ & 0.963 \\
\hline $\mathrm{C} 25-\mathrm{H} 252$ & 0.954 & $\mathrm{C} 25-\mathrm{H} 251$ & 0.970 \\
\hline O1-C2-N3 & $120.2(6)$ & $\mathrm{O} 1-\mathrm{C} 2-\mathrm{C} 15$ & $120.6(6)$ \\
\hline N3-C2-C15 & $119.1(6)$ & C2-N3-C4 & $121.5(6)$ \\
\hline C2-N3-H31 & 118.9 & C4-N3-H31 & 119.6 \\
\hline N3-C4-C5 & $109.2(5)$ & N3-C4-C8 & $111.0(6)$ \\
\hline $\mathrm{C} 5-\mathrm{C} 4-\mathrm{C} 8$ & $110.4(5)$ & N3-C4-H41 & 107.6 \\
\hline C5-C4-H41 & 109.2 & $\mathrm{C} 8-\mathrm{C} 4-\mathrm{H} 41$ & 109.4 \\
\hline C4-C5-O6 & $112.2(5)$ & $\mathrm{C} 4-\mathrm{C} 5-\mathrm{O} 7$ & $122.1(6)$ \\
\hline $\mathrm{O}-\mathrm{C} 5-\mathrm{O} 7$ & $125.7(6)$ & $\mathrm{C} 5-06-\mathrm{H} 61$ & 116.8 \\
\hline C4-C8-C9 & $112.8(6)$ & C4-C8-H81 & 107.9 \\
\hline $\mathrm{C} 9-\mathrm{C} 8-\mathrm{H} 81$ & 108.0 & $\mathrm{C} 4-\mathrm{C} 8-\mathrm{H} 82$ & 108.4 \\
\hline $\mathrm{C} 9-\mathrm{C} 8-\mathrm{H} 82$ & 108.6 & $\mathrm{H} 81-\mathrm{C} 8-\mathrm{H} 82$ & 111.1 \\
\hline
\end{tabular}




\begin{tabular}{|c|c|c|c|}
\hline C8-C9-C10 & $119.7(6)$ & C8-C9-C14 & $120.8(6)$ \\
\hline C10-C9-C14 & $119.5(6)$ & C9-C10-C11 & $119.6(7)$ \\
\hline C9-C10-H101 & 119.9 & $\mathrm{C} 11-\mathrm{C} 10-\mathrm{H} 101$ & 120.5 \\
\hline C10-C11-C12 & $120.3(7)$ & $\mathrm{C} 10-\mathrm{C} 11-\mathrm{H} 111$ & 119.2 \\
\hline C12-C11-H111 & 120.5 & C11-C12-C13 & $119.8(7)$ \\
\hline $\mathrm{C} 11-\mathrm{C} 12-\mathrm{H} 121$ & 120.1 & $\mathrm{C} 13-\mathrm{C} 12-\mathrm{H} 121$ & 120.1 \\
\hline C12-C13-C14 & $121.3(7)$ & $\mathrm{C} 12-\mathrm{C} 13-\mathrm{H} 131$ & 119.3 \\
\hline C14-C13-H131 & 119.4 & C13-C14-C9 & $119.5(7)$ \\
\hline C13-C14-H141 & 120.0 & C9-C14-H141 & 120.5 \\
\hline $\mathrm{C} 2-\mathrm{C} 15-\mathrm{C} 16$ & $113.3(6)$ & $\mathrm{C} 2-\mathrm{C} 15-\mathrm{H} 151$ & 108.0 \\
\hline $\mathrm{C} 16-\mathrm{C} 15-\mathrm{H} 151$ & 108.8 & $\mathrm{C} 2-\mathrm{C} 15-\mathrm{H} 152$ & 107.5 \\
\hline $\mathrm{C} 16-\mathrm{C} 15-\mathrm{H} 152$ & 107.4 & H151-C15-H152 & 111.9 \\
\hline C15-C16-C17 & $111.8(6)$ & $\mathrm{C} 15-\mathrm{C} 16-\mathrm{H} 161$ & 108.6 \\
\hline C17-C16-H161 & 109.1 & $\mathrm{C} 15-\mathrm{C} 16-\mathrm{H} 162$ & 108.2 \\
\hline C17-C16-H162 & 108.5 & H161-C16-H162 & 110.6 \\
\hline C16-C17-C18 & $114.1(6)$ & $\mathrm{C} 16-\mathrm{C} 17-\mathrm{H} 171$ & 107.2 \\
\hline $\mathrm{C} 18-\mathrm{C} 17-\mathrm{H} 171$ & 107.7 & $\mathrm{C} 16-\mathrm{C} 17-\mathrm{H} 172$ & 108.4 \\
\hline $\mathrm{C} 18-\mathrm{C} 17-\mathrm{H} 172$ & 109.2 & H171-C17-H172 & 110.2 \\
\hline C17-C18-C19 & $113.3(6)$ & $\mathrm{C} 17-\mathrm{C} 18-\mathrm{H} 181$ & 108.9 \\
\hline C19-C18-H181 & 109.1 & $\mathrm{C} 17-\mathrm{C} 18-\mathrm{H} 182$ & 108.0 \\
\hline C19-C18-H182 & 107.8 & H181-C18-H182 & 109.5 \\
\hline C18-C19-C20 & $116.0(6)$ & C18-C19-H191 & 107.8 \\
\hline C20-C19-H191 & 107.3 & C18-C19-H192 & 108.3 \\
\hline C20-C19-H192 & 107.4 & H191-C19-H192 & 110.0 \\
\hline C19-C20-C21 & $115.3(6)$ & $\mathrm{C} 19-\mathrm{C} 20-\mathrm{H} 201$ & 107.6 \\
\hline C21-C20-H201 & 107.4 & $\mathrm{C} 19-\mathrm{C} 20-\mathrm{H} 202$ & 108.5 \\
\hline $\mathrm{C} 21-\mathrm{C} 20-\mathrm{H} 202$ & 108.6 & $\mathrm{H} 201-\mathrm{C} 20-\mathrm{H} 202$ & 109.3 \\
\hline $\mathrm{C} 20-\mathrm{C} 21-\mathrm{C} 22$ & $112.5(6)$ & $\mathrm{C} 20-\mathrm{C} 21-\mathrm{H} 211$ & 109.3 \\
\hline $\mathrm{C} 22-\mathrm{C} 21-\mathrm{H} 211$ & 108.2 & $\mathrm{C} 20-\mathrm{C} 21-\mathrm{H} 212$ & 108.3 \\
\hline $\mathrm{C} 22-\mathrm{C} 21-\mathrm{H} 212$ & 108.7 & $\mathrm{H} 211-\mathrm{C} 21-\mathrm{H} 212$ & 109.7 \\
\hline $\mathrm{C} 21-\mathrm{C} 22-\mathrm{C} 23$ & $114.4(6)$ & $\mathrm{C} 21-\mathrm{C} 22-\mathrm{H} 221$ & 108.5 \\
\hline $\mathrm{C} 23-\mathrm{C} 22-\mathrm{H} 221$ & 108.8 & $\mathrm{C} 21-\mathrm{C} 22-\mathrm{H} 222$ & 107.1 \\
\hline $\mathrm{C} 23-\mathrm{C} 22-\mathrm{H} 222$ & 107.9 & $\mathrm{H} 221-\mathrm{C} 22-\mathrm{H} 222$ & 110.1 \\
\hline C22-C23-C24 & $115.6(6)$ & $\mathrm{C} 22-\mathrm{C} 23-\mathrm{H} 231$ & 106.8 \\
\hline $\mathrm{C} 24-\mathrm{C} 23-\mathrm{H} 231$ & 107.3 & $\mathrm{C} 22-\mathrm{C} 23-\mathrm{H} 232$ & 109.1 \\
\hline $\mathrm{C} 24-\mathrm{C} 23-\mathrm{H} 232$ & 107.5 & $\mathrm{H} 231-\mathrm{C} 23-\mathrm{H} 232$ & 110.5 \\
\hline C23-C24-C25 & $114.1(6)$ & $\mathrm{C} 23-\mathrm{C} 24-\mathrm{H} 241$ & 107.1 \\
\hline $\mathrm{C} 25-\mathrm{C} 24-\mathrm{H} 241$ & 108.0 & $\mathrm{C} 23-\mathrm{C} 24-\mathrm{H} 242$ & 107.9 \\
\hline $\mathrm{C} 25-\mathrm{C} 24-\mathrm{H} 242$ & 107.9 & H241-C24-H242 & 112.0 \\
\hline $\mathrm{C} 24-\mathrm{C} 25-\mathrm{H} 253$ & 110.7 & $\mathrm{C} 24-\mathrm{C} 25-\mathrm{H} 252$ & 108.8 \\
\hline $\mathrm{H} 253-\mathrm{C} 25-\mathrm{H} 252$ & 109.0 & $\mathrm{C} 24-\mathrm{C} 25-\mathrm{H} 251$ & 109.4 \\
\hline H253-C25-H251 & 109.1 & $\mathrm{H} 252-\mathrm{C} 25-\mathrm{H} 251$ & 109.8 \\
\hline
\end{tabular}


Table S6. Anisotropic displacement parameters $\left(\AA^{2} \times 10^{3}\right)$ for 4 a. The anisotropic displacement factor exponent takes the form: -2 ] ${ }^{2}\left[h^{2} a * 2 u^{11}+\ldots+2 h k a * b * u^{12}\right]$

\begin{tabular}{|c|c|c|c|c|c|c|}
\hline & $u^{11}$ & $u^{22}$ & $u^{33}$ & $u^{23}$ & $u^{13}$ & $U^{12}$ \\
\hline 01 & $23(2)$ & $25(2)$ & $21(3)$ & $-3(2)$ & $4(2)$ & $-8(2)$ \\
\hline$C 2$ & $18(3)$ & $16(3)$ & $17(3)$ & $-1(3)$ & $-3(3)$ & $-3(2)$ \\
\hline N3 & 22 & 16 & 17 & -4 & 0 & 0 \\
\hline C4 & $11(2)$ & $15(3)$ & 19(3) & $0(3)$ & $2(3)$ & $-2(2)$ \\
\hline C5 & $15(3)$ & $17(3)$ & $16(3)$ & $-2(3)$ & $6(3)$ & $1(2)$ \\
\hline 06 & $14(2)$ & $33(3)$ & $16(2)$ & $3(2)$ & $-4(2)$ & $4(2)$ \\
\hline 07 & $28(2)$ & $42(3)$ & $7(2)$ & $4(2)$ & $2(2)$ & $1(2)$ \\
\hline C8 & $24(3)$ & $14(3)$ & $20(3)$ & $-1(3)$ & $4(3)$ & $2(2)$ \\
\hline C9 & $15(3)$ & $12(3)$ & $24(3)$ & $1(3)$ & $8(3)$ & $-1(2)$ \\
\hline C10 & $30(3)$ & $15(3)$ & $33(4)$ & $1(3)$ & $3(3)$ & $2(3)$ \\
\hline C11 & $45(4)$ & $17(3)$ & $22(4)$ & $3(3)$ & $4(4)$ & $2(3)$ \\
\hline C12 & $48(5)$ & $16(3)$ & $26(4)$ & $-5(3)$ & $-14(4)$ & $7(3)$ \\
\hline C13 & $36(4)$ & $20(3)$ & $32(4)$ & $-3(3)$ & $-10(4)$ & $-4(3)$ \\
\hline C14 & $22(3)$ & $18(3)$ & $22(3)$ & $-2(3)$ & $-7(3)$ & $1(3)$ \\
\hline C15 & $21(3)$ & $13(3)$ & $26(3)$ & $1(3)$ & $-7(3)$ & $-3(2)$ \\
\hline C16 & $30(3)$ & $14(3)$ & $17(3)$ & $-2(3)$ & $-8(3)$ & $-3(3)$ \\
\hline C17 & $33(4)$ & $15(3)$ & $19(3)$ & $-4(3)$ & $-17(3)$ & $-2(3)$ \\
\hline C18 & $27(3)$ & $11(2)$ & $27(4)$ & $-2(3)$ & $3(3)$ & $-5(2)$ \\
\hline C19 & $35(4)$ & $18(3)$ & $10(3)$ & $-1(3)$ & $8(3)$ & $-7(3)$ \\
\hline C20 & $25(3)$ & $23(3)$ & $13(3)$ & $0(3)$ & $6(3)$ & $-3(3)$ \\
\hline C21 & $38(4)$ & $17(3)$ & $17(3)$ & $0(3)$ & $5(3)$ & $-1(3)$ \\
\hline C22 & $23(3)$ & $20(3)$ & $11(3)$ & $-1(3)$ & $1(3)$ & $0(3)$ \\
\hline C23 & $20(3)$ & $22(3)$ & $21(3)$ & $0(3)$ & $-4(3)$ & $-2(3)$ \\
\hline C24 & $27(3)$ & $20(3)$ & $23(4)$ & $1(3)$ & $2(3)$ & $-2(3)$ \\
\hline C25 & $43(4)$ & $21(3)$ & $20(4)$ & $3(3)$ & $7(3)$ & $2(3)$ \\
\hline
\end{tabular}


Table S7. Hydrogen coordinates $\left(\times 10^{4}\right)$ and isotropic displacement parameters $\left(\AA^{2} \times 10^{3}\right)$ for compound 4 a.

\begin{tabular}{|c|c|c|c|c|}
\hline & $x$ & $y$ & $z$ & Ueq \\
\hline H41 & 6659 & 8064 & 5407 & 15 \\
\hline H81 & 7858 & 8560 & 1793 & 22 \\
\hline H82 & 6619 & 8620 & 2171 & 22 \\
\hline $\mathrm{H} 101$ & 5986 & 8953 & 6296 & 30 \\
\hline $\mathrm{H} 111$ & 6314 & 9509 & 9329 & 30 \\
\hline $\mathrm{H} 121$ & 7979 & 9832 & 9721 & 32 \\
\hline H131 & 9315 & 9588 & 7183 & 36 \\
\hline $\mathrm{H} 141$ & 9021 & 9027 & 4138 & 23 \\
\hline H151 & 6525 & 7137 & -774 & 22 \\
\hline $\mathrm{H} 152$ & 5329 & 7074 & 229 & 22 \\
\hline $\mathrm{H} 161$ & 7085 & 6534 & 1753 & 24 \\
\hline H162 & 5938 & 6501 & 3011 & 24 \\
\hline $\mathrm{H} 171$ & 6305 & 6305 & -2076 & 25 \\
\hline $\mathrm{H} 172$ & 5213 & 6226 & -647 & 25 \\
\hline $\mathrm{H} 181$ & 7092 & 5706 & 93 & 24 \\
\hline $\mathrm{H} 182$ & 6046 & 5636 & 1695 & 24 \\
\hline H191 & 6132 & 5475 & -3488 & 25 \\
\hline $\mathrm{H} 192$ & 5140 & 5369 & -1722 & 25 \\
\hline $\mathrm{H} 201$ & 7061 & 4888 & -1395 & 24 \\
\hline $\mathrm{H} 2 \mathrm{O} 2$ & 6083 & 4704 & -2954 & 24 \\
\hline $\mathrm{H} 211$ & 6180 & 4784 & 2348 & 28 \\
\hline $\mathrm{H} 212$ & 5123 & 4656 & 884 & 28 \\
\hline $\mathrm{H} 221$ & 6964 & 4109 & 860 & 22 \\
\hline $\mathrm{H} 222$ & 5892 & 3986 & -549 & 22 \\
\hline $\mathrm{H} 231$ & 6213 & 3981 & 4631 & 24 \\
\hline $\mathrm{H} 232$ & 5064 & 3937 & 3456 & 24 \\
\hline $\mathrm{H} 241$ & 6677 & 3285 & 2783 & 26 \\
\hline $\mathrm{H} 242$ & 5480 & 3232 & 1779 & 26 \\
\hline $\mathrm{H} 253$ & 5702 & 2776 & 5333 & 39 \\
\hline $\mathrm{H} 252$ & 6079 & 3209 & 6828 & 39 \\
\hline $\mathrm{H} 251$ & 4907 & 3178 & 5922 & 39 \\
\hline H61 & 9623 & 7897 & 4550 & 30 \\
\hline H31 & 7364 & 7723 & 944 & 22 \\
\hline
\end{tabular}


A colorless crystal of $\mathbf{4 b}$ (approximate dimensions $0.70 \times 0.15 \times 0.08 \mathrm{~mm}^{3}$ ) was placed on a Bruker Apex Duo diffractometer diffractometer equipped with an ApexII CCD detector at $90 \mathrm{~K}$.

Data collection

The data collection was carried out using Mo K $\alpha$ radiation $(\lambda=0.71073 \AA$, graphite monochromator) with a frame time of 15 seconds and a detector distance of $40 \mathrm{~mm}$. A collection strategy was calculated and complete data to a resolution of $0.77 \AA$ with a redundancy of 2.5 were collected. Data to a resolution of $0.77 \AA$ were considered in the reduction. Final cell constants were calculated from the xyz centroids of 4786 strong reflections from the actual data collection after integration (SAINT). ${ }^{9}$ The intensity data were corrected for absorption (SADABS). ${ }^{10}$ Please refer to Table 1 for additional crystal and refinement information.

Structure solution and refinement

The space group $\mathrm{P} 2_{1}$ was determined based on intensity statistics and systematic absences. The structure was solved using Superflip ${ }^{11}$ and refined using full-matrix least-squares on $\mathrm{F}^{2}$ within the CRYSTALS suite. ${ }^{12}$ A charge-flipping solution was calculated, which provided most non-hydrogen atoms from the E-map. Full-matrix least squares / difference Fourier cycles were performed, which located the remaining non-hydrogen atoms. All non-hydrogen atoms were refined with anisotropic displacement parameters. Hydrogen atoms were initially refined with restraints on bond lengths and angles, after which the positions were used as the basis for a riding model. ${ }^{13}$ The final full matrix least squares refinement converged to $\mathrm{R} 1=0.0363$ and $\mathrm{wR} 2=0.0918$ $\left(\mathrm{F}^{2}\right.$, all data). The goodness-of-fit was 0.9748 . On the basis of the final model, the calculated density was $1.157 \mathrm{~g} / \mathrm{cm}^{3}$ and $\mathrm{F}(000)$, $380 \mathrm{e}^{-}$. 
Table S8. Crystal data and structure refinement for compound $\mathbf{4 b .}$

\begin{tabular}{|c|c|c|}
\hline Empirical formula & \multicolumn{2}{|l|}{$\mathrm{C} 21 \mathrm{H} 34 \mathrm{~N} 2 \mathrm{O} 2$} \\
\hline Formula weight & \multicolumn{2}{|l|}{346.51} \\
\hline Crystal color, shape, size & \multicolumn{2}{|c|}{ colorless plate, $0.70 \times 0.15 \times 0.08 \mathrm{~mm}^{3}$} \\
\hline Temperature & \multicolumn{2}{|l|}{$90 \mathrm{~K}$} \\
\hline Wavelength & \multicolumn{2}{|l|}{$0.71073 \AA$} \\
\hline Crystal system, space group & \multicolumn{2}{|l|}{ Monoclinic, $\mathrm{P} 2{ }_{1}$} \\
\hline \multirow[t]{3}{*}{ Unit cell dimensions } & $a=8.697(5) \AA$ & $\alpha=90^{\circ}$ \\
\hline & $\mathrm{b}=4.949(3) \AA$ & $\beta=94.349(14)^{\circ}$. \\
\hline & $c=23.171(12) \AA$ & $\gamma=90^{\circ}$. \\
\hline Volume & \multicolumn{2}{|l|}{$994.4(9) \AA^{3}$} \\
\hline Z & \multicolumn{2}{|l|}{2} \\
\hline Density (calculated) & \multicolumn{2}{|l|}{$1.157 \mathrm{~g} / \mathrm{cm}^{3}$} \\
\hline Absorption coefficient & \multicolumn{2}{|l|}{$0.074 \mathrm{~mm}^{-1}$} \\
\hline$F(000)$ & \multicolumn{2}{|l|}{380} \\
\hline
\end{tabular}

\section{Data collection}

Diffractometer

Theta range for data collection

Index ranges

Reflections collected

Independent reflections

Observed Reflections

Completeness to theta $=26.924^{\circ}$

Kappa Apex II Duo, Bruker

0.881 to $27.757^{\circ}$.

$-11<=\mathrm{h}<=11,-6<=\mathrm{k}<=6,-30<=\mathrm{k}<=30$

17895

2566 [Rint $=0.055]$

2181

$99.5 \%$

\section{Solution and Refinement}

Absorption correction

Semi-empirical from equivalents

Max. and min. transmission

1.00 and 0.83

Solution

Refinement method

Intrinsic methods

Full-matrix least-squares on $\mathrm{F}^{2}$

Weighting scheme

Chebychev polynomial (Watkin 1994, Prince 1982)

Data / restraints / parameters

2555 / 1 / 226

Goodness-of-fit on $\mathrm{F}^{2}$

0.9748

Final $R$ indices $[1>2 \sigma(I)]$

$\mathrm{R} 1=0.0363, w R 2=0.0841$

$R$ indices (all data)

$R 1=0.0467, w R 2=0.0918$

Largest diff. peak and hole 
Table 59. Atomic coordinates $\left(\times 10^{4}\right)$ and equivalent isotropic displacement parameters $\left(\AA^{2} \times 10^{3}\right)$ for $\mathbf{4 b .} U(\mathrm{eq})$ is defined as one third of the trace of the orthogonalized $\mathrm{U}^{\mathrm{ij}}$ tensor.

\begin{tabular}{|c|c|c|c|c|}
\hline & $x$ & $y$ & z & $\mathrm{U}(\mathrm{eq})$ \\
\hline 01 & $3870(2)$ & $2205(3)$ & $7882(1)$ & 18 \\
\hline$C 2$ & $3716(2)$ & $4677(4)$ & 7873(1) & 14 \\
\hline N3 & $4708(2)$ & $6353(3)$ & $8169(1)$ & 14 \\
\hline C4 & $6022(2)$ & $5347(4)$ & $8533(1)$ & 14 \\
\hline C5 & $5745(2)$ & $5870(4)$ & $9166(1)$ & 14 \\
\hline 06 & $5520(2)$ & $8193(3)$ & $9334(1)$ & 20 \\
\hline N7 & $5767(2)$ & $3728(4)$ & $9508(1)$ & 16 \\
\hline C8 & $7516(2)$ & $6693(4)$ & $8371(1)$ & 17 \\
\hline C9 & $8948(2)$ & $5600(4)$ & $8702(1)$ & 19 \\
\hline C10 & $9501(2)$ & $6808(5)$ & $9217(1)$ & 29 \\
\hline C11 & 10828(3) & $5860(7)$ & $9521(1)$ & 42 \\
\hline C12 & 11598(3) & $3680(7)$ & $9316(1)$ & 44 \\
\hline C13 & 11062(3) & $2440(6)$ & $8804(1)$ & 39 \\
\hline C14 & $9727(2)$ & $3402(5)$ & $8498(1)$ & 27 \\
\hline C15 & $2381(2)$ & $6059(4)$ & $7534(1)$ & 14 \\
\hline C16 & $1924(2)$ & $4697(4)$ & $6959(1)$ & 16 \\
\hline C17 & $502(2)$ & $5999(4)$ & $6646(1)$ & 15 \\
\hline C18 & $80(2)$ & $4768(4)$ & $6052(1)$ & 15 \\
\hline C19 & $-1368(2)$ & $6016(4)$ & $5745(1)$ & 15 \\
\hline C20 & $-1779(2)$ & $4802(4)$ & $5149(1)$ & 15 \\
\hline C21 & $-3239(2)$ & $6033(4)$ & $4844(1)$ & 15 \\
\hline C22 & $-3663(2)$ & $4833(4)$ & $4248(1)$ & 14 \\
\hline $\mathrm{C} 23$ & $-5106(2)$ & $6083(4)$ & $3944(1)$ & 15 \\
\hline C24 & $-5519(2)$ & $4936(4)$ & $3342(1)$ & 17 \\
\hline C25 & $-6925(2)$ & $6306(5)$ & $3035(1)$ & 24 \\
\hline
\end{tabular}


Table S10. Bond lengths $[\AA \AA]$ and angles $\left[^{\circ}\right]$ for compound $\mathbf{4 b}$.

\begin{tabular}{|c|c|c|c|}
\hline $\mathrm{O} 1-\mathrm{C} 2$ & $1.231(2)$ & $\mathrm{C} 2-\mathrm{N} 3$ & $1.347(2)$ \\
\hline C2-C15 & $1.514(2)$ & N3-C4 & $1.455(2)$ \\
\hline N3-H31 & 0.891 & $\mathrm{C} 4-\mathrm{C} 5$ & $1.525(2)$ \\
\hline $\mathrm{C} 4-\mathrm{C} 8$ & $1.532(2)$ & $\mathrm{C} 4-\mathrm{H} 41$ & 0.991 \\
\hline C5-O6 & $1.234(2)$ & C5-N7 & $1.323(2)$ \\
\hline N7-H71 & 0.885 & N7-H72 & 0.888 \\
\hline $\mathrm{C} 8-\mathrm{C} 9$ & $1.513(2)$ & $\mathrm{C} 8-\mathrm{H} 81$ & 0.989 \\
\hline $\mathrm{C} 8-\mathrm{H} 82$ & 0.959 & C9-C10 & $1.387(3)$ \\
\hline C9-C14 & $1.383(3)$ & C10-C11 & $1.388(3)$ \\
\hline $\mathrm{C} 10-\mathrm{H} 101$ & 0.948 & $\mathrm{C} 11-\mathrm{C} 12$ & $1.374(5)$ \\
\hline C11-H111 & 0.956 & C12-C13 & $1.384(4)$ \\
\hline $\mathrm{C} 12-\mathrm{H} 121$ & 0.936 & C13-C14 & $1.397(3)$ \\
\hline $\mathrm{C} 13-\mathrm{H} 131$ & 0.937 & $\mathrm{C} 14-\mathrm{H} 141$ & 0.942 \\
\hline C15-C16 & $1.520(2)$ & $\mathrm{C} 15-\mathrm{H} 152$ & 0.977 \\
\hline $\mathrm{C} 15-\mathrm{H} 151$ & 0.971 & $\mathrm{C} 16-\mathrm{C} 17$ & $1.527(2)$ \\
\hline $\mathrm{C} 16-\mathrm{H} 162$ & 0.981 & $\mathrm{C} 16-\mathrm{H} 161$ & 0.968 \\
\hline C17-C18 & $1.524(2)$ & $\mathrm{C} 17-\mathrm{H} 172$ & 0.986 \\
\hline C17-H171 & 0.987 & C18-C19 & $1.530(2)$ \\
\hline C18-H181 & 0.982 & $\mathrm{C} 18-\mathrm{H} 182$ & 0.985 \\
\hline C19-C20 & $1.523(2)$ & C19-H191 & 0.990 \\
\hline C19-H192 & 0.979 & C20-C21 & $1.532(2)$ \\
\hline C20-H2O1 & 0.971 & $\mathrm{C} 20-\mathrm{H} 2 \mathrm{O} 2$ & 0.987 \\
\hline C21-C22 & $1.523(2)$ & $\mathrm{C} 21-\mathrm{H} 211$ & 0.978 \\
\hline $\mathrm{C} 21-\mathrm{H} 212$ & 0.982 & $\mathrm{C} 22-\mathrm{C} 23$ & $1.522(2)$ \\
\hline $\mathrm{C} 22-\mathrm{H} 221$ & 0.984 & $\mathrm{C} 22-\mathrm{H} 222$ & 0.977 \\
\hline C23-C24 & $1.524(2)$ & $\mathrm{C} 23-\mathrm{H} 231$ & 0.977 \\
\hline $\mathrm{C} 23-\mathrm{H} 232$ & 0.974 & C24-C25 & $1.525(3)$ \\
\hline $\mathrm{C} 24-\mathrm{H} 241$ & 0.970 & $\mathrm{C} 24-\mathrm{H} 242$ & 0.977 \\
\hline $\mathrm{C} 25-\mathrm{H} 251$ & 0.970 & $\mathrm{C} 25-\mathrm{H} 253$ & 0.963 \\
\hline $\mathrm{C} 25-\mathrm{H} 252$ & 0.983 & & \\
\hline O1-C2-N3 & $122.62(18)$ & $\mathrm{O} 1-\mathrm{C} 2-\mathrm{C} 15$ & $122.38(18)$ \\
\hline N3-C2-C15 & $115.00(17)$ & $\mathrm{C} 2-\mathrm{N} 3-\mathrm{C} 4$ & $121.97(16)$ \\
\hline C2-N3-H31 & 119.3 & C4-N3-H31 & 118.7 \\
\hline N3-C4-C5 & $108.96(15)$ & N3-C4-C8 & $110.61(14)$ \\
\hline $\mathrm{C} 5-\mathrm{C} 4-\mathrm{C} 8$ & $111.14(14)$ & N3-C4-H41 & 107.6 \\
\hline C5-C4-H41 & 108.6 & $\mathrm{C} 8-\mathrm{C} 4-\mathrm{H} 41$ & 109.8 \\
\hline C4-C5-O6 & $120.16(16)$ & C4-C5-N7 & $116.36(16)$ \\
\hline O6-C5-N7 & $123.48(16)$ & C5-N7-H71 & 120.2 \\
\hline C5-N7-H72 & 120.9 & H71-N7-H72 & 117.3 \\
\hline $\mathrm{C} 4-\mathrm{C} 8-\mathrm{C} 9$ & $113.64(15)$ & $\mathrm{C} 4-\mathrm{C} 8-\mathrm{H} 81$ & 105.8 \\
\hline
\end{tabular}




\begin{tabular}{|c|c|c|c|}
\hline $\mathrm{C} 9-\mathrm{C} 8-\mathrm{H} 81$ & 110.8 & $\mathrm{C} 4-\mathrm{C} 8-\mathrm{H} 82$ & 107.5 \\
\hline $\mathrm{C} 9-\mathrm{C} 8-\mathrm{H} 82$ & 108.5 & $\mathrm{H} 81-\mathrm{C} 8-\mathrm{H} 82$ & 110.6 \\
\hline C8-C9-C10 & $120.04(19)$ & C8-C9-C14 & $120.91(18)$ \\
\hline C10-C9-C14 & 119.05(19) & C9-C10-C11 & $120.8(2)$ \\
\hline C9-C10-H101 & 120.3 & C11-C10-H101 & 118.9 \\
\hline C10-C11-C12 & 119.9(3) & $\mathrm{C} 10-\mathrm{C} 11-\mathrm{H} 111$ & 119.1 \\
\hline C12-C11-H111 & 121.0 & $\mathrm{C} 11-\mathrm{C} 12-\mathrm{C} 13$ & $120.3(2)$ \\
\hline $\mathrm{C} 11-\mathrm{C} 12-\mathrm{H} 121$ & 121.1 & $\mathrm{C} 13-\mathrm{C} 12-\mathrm{H} 121$ & 118.7 \\
\hline C12-C13-C14 & 119.7(3) & $\mathrm{C} 12-\mathrm{C} 13-\mathrm{H} 131$ & 122.0 \\
\hline C14-C13-H131 & 118.3 & C13-C14-C9 & $120.3(2)$ \\
\hline C13-C14-H141 & 119.6 & C9-C14-H141 & 120.0 \\
\hline C2-C15-C16 & $113.19(16)$ & $\mathrm{C} 2-\mathrm{C} 15-\mathrm{H} 152$ & 107.1 \\
\hline C16-C15-H152 & 108.0 & $\mathrm{C} 2-\mathrm{C} 15-\mathrm{H} 151$ & 109.2 \\
\hline C16-C15-H151 & 110.8 & H152-C15-H151 & 108.3 \\
\hline C15-C16-C17 & $112.18(16)$ & C15-C16-H162 & 106.7 \\
\hline C17-C16-H162 & 108.8 & C15-C16-H161 & 110.0 \\
\hline C17-C16-H161 & 109.7 & H162-C16-H161 & 109.4 \\
\hline C16-C17-C18 & $112.97(16)$ & C16-C17-H172 & 108.2 \\
\hline C18-C17-H172 & 109.7 & C16-C17-H171 & 108.6 \\
\hline C18-C17-H171 & 108.9 & H172-C17-H171 & 108.3 \\
\hline C17-C18-C19 & $113.11(15)$ & C17-C18-H181 & 107.6 \\
\hline C19-C18-H181 & 108.7 & C17-C18-H182 & 110.0 \\
\hline C19-C18-H182 & 109.3 & H181-C18-H182 & 107.8 \\
\hline C18-C19-C20 & $113.01(15)$ & C18-C19-H191 & 109.4 \\
\hline C20-C19-H191 & 108.0 & C18-C19-H192 & 109.4 \\
\hline C20-C19-H192 & 108.8 & H191-C19-H192 & 108.1 \\
\hline C19-C20-C21 & $113.01(15)$ & C19-C20-H201 & 108.8 \\
\hline C21-C2O-H2O1 & 108.3 & C19-C2O-H2O2 & 109.1 \\
\hline C21-C2O-H2O2 & 109.6 & $\mathrm{H} 201-\mathrm{C} 20-\mathrm{H} 202$ & 107.9 \\
\hline C20-C21-C22 & $113.52(15)$ & $\mathrm{C} 20-\mathrm{C} 21-\mathrm{H} 211$ & 109.3 \\
\hline $\mathrm{C} 22-\mathrm{C} 21-\mathrm{H} 211$ & 108.2 & $\mathrm{C} 20-\mathrm{C} 21-\mathrm{H} 212$ & 109.6 \\
\hline $\mathrm{C} 22-\mathrm{C} 21-\mathrm{H} 212$ & 108.1 & $\mathrm{H} 211-\mathrm{C} 21-\mathrm{H} 212$ & 108.0 \\
\hline $\mathrm{C} 21-\mathrm{C} 22-\mathrm{C} 23$ & $113.26(15)$ & $\mathrm{C} 21-\mathrm{C} 22-\mathrm{H} 221$ & 108.2 \\
\hline $\mathrm{C} 23-\mathrm{C} 22-\mathrm{H} 221$ & 108.8 & $\mathrm{C} 21-\mathrm{C} 22-\mathrm{H} 222$ & 108.2 \\
\hline $\mathrm{C} 23-\mathrm{C} 22-\mathrm{H} 222$ & 110.0 & $\mathrm{H} 221-\mathrm{C} 22-\mathrm{H} 222$ & 108.2 \\
\hline C22-C23-C24 & $113.61(16)$ & $\mathrm{C} 22-\mathrm{C} 23-\mathrm{H} 231$ & 108.4 \\
\hline $\mathrm{C} 24-\mathrm{C} 23-\mathrm{H} 231$ & 109.3 & $\mathrm{C} 22-\mathrm{C} 23-\mathrm{H} 232$ & 110.1 \\
\hline $\mathrm{C} 24-\mathrm{C} 23-\mathrm{H} 232$ & 108.6 & $\mathrm{H} 231-\mathrm{C} 23-\mathrm{H} 232$ & 106.6 \\
\hline C23-C24-C25 & $112.69(16)$ & $\mathrm{C} 23-\mathrm{C} 24-\mathrm{H} 241$ & 107.8 \\
\hline $\mathrm{C} 25-\mathrm{C} 24-\mathrm{H} 241$ & 108.2 & $\mathrm{C} 23-\mathrm{C} 24-\mathrm{H} 242$ & 110.2 \\
\hline $\mathrm{C} 25-\mathrm{C} 24-\mathrm{H} 242$ & 108.6 & $\mathrm{H} 241-\mathrm{C} 24-\mathrm{H} 242$ & 109.2 \\
\hline $\mathrm{C} 24-\mathrm{C} 25-\mathrm{H} 251$ & 109.4 & $\mathrm{C} 24-\mathrm{C} 25-\mathrm{H} 253$ & 111.2 \\
\hline $\mathrm{H} 251-\mathrm{C} 25-\mathrm{H} 253$ & 109.4 & $\mathrm{C} 24-\mathrm{C} 25-\mathrm{H} 252$ & 109.6 \\
\hline
\end{tabular}


Table S11. Anisotropic displacement parameters $\left(\AA^{2} \times 10^{3}\right)$ for $\mathbf{4 b}$. The anisotropic displacement factor exponent takes the form: -2$]^{2}\left[h^{2} a^{* 2} u^{11}+\ldots+2 h k a^{*} b^{*} u^{12}\right]$

\begin{tabular}{|c|c|c|c|c|c|c|}
\hline & $u^{11}$ & $u^{22}$ & $u^{33}$ & $u^{23}$ & $u^{13}$ & $u^{12}$ \\
\hline 01 & $23(1)$ & $12(1)$ & $18(1)$ & $0(1)$ & $-5(1)$ & $0(1)$ \\
\hline C2 & $16(1)$ & $16(1)$ & $8(1)$ & $-1(1)$ & $-1(1)$ & $0(1)$ \\
\hline N3 & 18(1) & 10(1) & $13(1)$ & $0(1)$ & $-6(1)$ & $-1(1)$ \\
\hline C4 & $17(1)$ & $13(1)$ & $10(1)$ & $-1(1)$ & $-3(1)$ & $1(1)$ \\
\hline C5 & $15(1)$ & $14(1)$ & $11(1)$ & $0(1)$ & $-5(1)$ & $-1(1)$ \\
\hline 06 & $36(1)$ & 11(1) & $13(1)$ & $-2(1)$ & $0(1)$ & $0(1)$ \\
\hline N7 & $24(1)$ & $12(1)$ & $11(1)$ & 1(1) & $0(1)$ & $0(1)$ \\
\hline C8 & $20(1)$ & $21(1)$ & $10(1)$ & $4(1)$ & $0(1)$ & $-1(1)$ \\
\hline C9 & $18(1)$ & $22(1)$ & $18(1)$ & $8(1)$ & $-1(1)$ & $-4(1)$ \\
\hline C10 & $27(1)$ & $34(1)$ & $24(1)$ & $7(1)$ & $-9(1)$ & $-7(1)$ \\
\hline C11 & $32(1)$ & $49(2)$ & $41(1)$ & 19(1) & $-18(1)$ & $-13(1)$ \\
\hline C12 & $16(1)$ & $62(2)$ & $54(1)$ & $32(2)$ & $-8(1)$ & $-4(1)$ \\
\hline C13 & $25(1)$ & $40(2)$ & $55(2)$ & $28(1)$ & $15(1)$ & $11(1)$ \\
\hline C14 & 21(1) & $30(1)$ & $31(1)$ & $11(1)$ & $8(1)$ & $0(1)$ \\
\hline C15 & $17(1)$ & 13(1) & $12(1)$ & $-1(1)$ & $-2(1)$ & $-1(1)$ \\
\hline C16 & 15(1) & $18(1)$ & $13(1)$ & $-2(1)$ & $-5(1)$ & $2(1)$ \\
\hline C17 & $16(1)$ & $17(1)$ & $11(1)$ & $-2(1)$ & $-4(1)$ & $1(1)$ \\
\hline C18 & 15(1) & 19(1) & $12(1)$ & $-1(1)$ & $-4(1)$ & $1(1)$ \\
\hline C19 & $17(1)$ & $16(1)$ & $12(1)$ & $-1(1)$ & $-3(1)$ & $1(1)$ \\
\hline C20 & 13(1) & 18(1) & $13(1)$ & $0(1)$ & $-2(1)$ & $0(1)$ \\
\hline C21 & $15(1)$ & $16(1)$ & $12(1)$ & $0(1)$ & $-2(1)$ & $1(1)$ \\
\hline C22 & 15(1) & $17(1)$ & $11(1)$ & $-1(1)$ & $-1(1)$ & $1(1)$ \\
\hline $\mathrm{C} 23$ & $16(1)$ & $17(1)$ & $12(1)$ & $0(1)$ & $-3(1)$ & $1(1)$ \\
\hline C24 & $17(1)$ & $20(1)$ & $13(1)$ & $-2(1)$ & $-1(1)$ & $2(1)$ \\
\hline C25 & $26(1)$ & $26(1)$ & $17(1)$ & $-4(1)$ & $-9(1)$ & $5(1)$ \\
\hline
\end{tabular}


Table S12. Hydrogen coordinates $\left(\times 10^{4}\right)$ and isotropic displacement parameters $\left(\AA^{2} \times 10^{3}\right)$ for compound $\mathbf{4 b}$.

\begin{tabular}{|c|c|c|c|c|}
\hline & $x$ & $y$ & $z$ & Ueq \\
\hline H41 & 6082 & 3370 & 8472 & 16 \\
\hline H81 & 7390 & 8643 & 8448 & 21 \\
\hline H82 & 7601 & 6381 & 7966 & 21 \\
\hline $\mathrm{H} 101$ & 8980 & 8310 & 9365 & 35 \\
\hline $\mathrm{H} 111$ & 11170 & 6702 & 9880 & 50 \\
\hline $\mathrm{H} 121$ & 12499 & 3020 & 9513 & 54 \\
\hline $\mathrm{H} 131$ & 11555 & 931 & 8658 & 48 \\
\hline $\mathrm{H} 141$ & 9383 & 2593 & 8144 & 32 \\
\hline H152 & 1500 & 5976 & 7771 & 17 \\
\hline H151 & 2638 & 7945 & 7478 & 18 \\
\hline $\mathrm{H} 162$ & 1684 & 2809 & 7046 & 20 \\
\hline H161 & 2775 & 4752 & 6713 & 18 \\
\hline $\mathrm{H} 172$ & -368 & 5797 & 6892 & 18 \\
\hline $\mathrm{H} 171$ & 706 & 7946 & 6600 & 19 \\
\hline $\mathrm{H} 181$ & -100 & 2829 & 6108 & 18 \\
\hline $\mathrm{H} 182$ & 948 & 4961 & 5806 & 18 \\
\hline H191 & -2254 & 5732 & 5983 & 18 \\
\hline $\mathrm{H} 192$ & -1218 & 7965 & 5703 & 18 \\
\hline $\mathrm{H} 201$ & -1943 & 2874 & 5192 & 18 \\
\hline $\mathrm{H} 2 \mathrm{O} 2$ & -904 & 5056 & 4907 & 18 \\
\hline $\mathrm{H} 211$ & -4106 & 5749 & 5082 & 18 \\
\hline $\mathrm{H} 212$ & -3099 & 7989 & 4799 & 18 \\
\hline $\mathrm{H} 221$ & -3833 & 2882 & 4293 & 18 \\
\hline $\mathrm{H} 222$ & -2787 & 5081 & 4012 & 18 \\
\hline $\mathrm{H} 231$ & -5965 & 5791 & 4185 & 19 \\
\hline $\mathrm{H} 232$ & -4980 & 8032 & 3912 & 18 \\
\hline $\mathrm{H} 241$ & -5752 & 3032 & 3384 & 20 \\
\hline $\mathrm{H} 242$ & -4649 & 5131 & 3102 & 20 \\
\hline $\mathrm{H} 251$ & -7107 & 5572 & 2648 & 35 \\
\hline $\mathrm{H} 253$ & -7829 & 6040 & 3244 & 36 \\
\hline $\mathrm{H} 252$ & -6728 & 8254 & 3001 & 37 \\
\hline H31 & 4582 & 8133 & 8132 & 20 \\
\hline H71 & 5522 & 3889 & 9870 & 21 \\
\hline $\mathrm{H} 72$ & 5800 & 2070 & 9363 & 22 \\
\hline
\end{tabular}




\section{References}

(1) Molecular Gels: Materials with Self-Assembled Fibrillar Networks; Weiss, R. G., Terech, P., Eds.; Springer: Dordrecht, 2006.

(2) Pal, A.; Mahapatra, R. Das; Dey, J. Understanding the Role of H - Bonding in Self-Aggregation in Organic Liquids by Fatty Acid Amphiphiles with a Hydrocarbon Tail Containing Different H - Bonding Linker Groups. Langmuir 2014, 30, 1379113798.

(3) Ren, C.; Hwee Boon Ng, G.; Wu, H.; Chan, K.-H.; Shen, J.; Teh, C.; Ying, J. Y.; Zeng, H. Instant Room-Temperature Gelation of Crude Oil by Chiral Organogelators. Chem. Mater. 2016, 28, 4001-4008.

(4) Ren, C.; Chen, F.; Zhou, F.; Shen, J.; Su, H.; Zeng, H. Low-Cost Phase-Selective Organogelators for Rapid Gelation of Crude Oils at Room Temperature. Langmuir 2016, 32, 13510-13516.

(5) Dastidar, P.; Roy, R.; Parveen, R.; Sarkar, K. Supramolecular Synthon Approach in Designing Molecular Gels for Advanced Therapeutics. Adv. Ther. 2019, 2, 1800061.

(6) Zhuan, C.; Li, Y.; Yuan, X.; Zhao, J.; Hou, X. A Sorbitol-Based Phase-Selective Organogelator for Crude Oil Spills Treatment. J. Appl. Polym. Sci. 2019, 136, 47052.

(7) Pal, A.; Ghosh, Y. K.; Bhattacharya, S. Molecular Mechanism of Physical Gelation of Hydrocarbons by Fatty Acid Amides of Natural Amino Acids. Tetrahedron 2007, 63, 7334-7348.

(8) Janiak, C. A Critical Account on $\pi-\pi$ Stacking in Metal Complexes with Aromatic Nitrogen-Containing Ligands $\dagger$. J. Chem. Soc. Dalton Trans. 2000, No. 21, 3885-3896.

(9) Bruker Analytical X-Ray Systems. SAINT. Bruker: Madison, WI.

(10) Bruker Analytical X-Ray Systems. SADABS. Bruker Analytical X-Ray Systems: Madison, WI.

(11) Palatinus, L.; Chapuis, G. SUPERFLIP - a Computer Program for the Solution of Crystal Structures by Charge Flipping in Arbitrary Dimensions. J. Appl. Crystallogr. 2007, 40, 786-790.

(12) Betteridge, P. W.; Carruthers, J. R.; Cooper, R. I.; Prout, K.; Watkin, D. J. CRYSTALS Version 12: Software for Guided Crystal Structure Analysis. J. Appl. Crystallogr. 2003, 36, 1487.

(13) Cooper, R. I.; Thompson, A. L.; Watkin, D. J. CRYSTALS Enhancements: Dealing with Hydrogen Atoms in Refinement. J. Appl. Crystallogr. 2010, 43, 1100-1107. 